\title{
النظر العقلي وأثره في تزكية النفوس \\ مقدمة في ضرورة بناء علم التز كية على الحقائق الثابتة
}

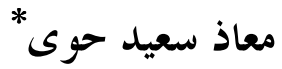

\section{مقدمة: إشكالات غياب الفكر في علم التز كية}

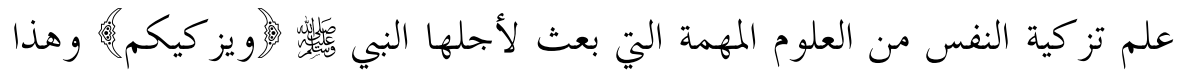
العلم فيما آل إليه بعد النبي

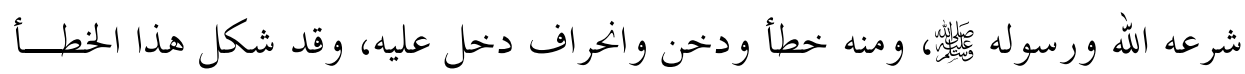

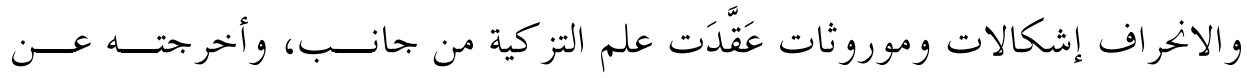

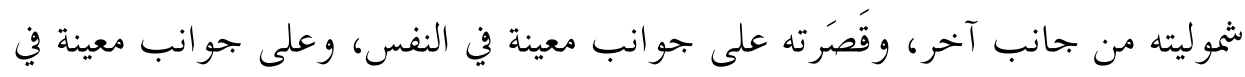

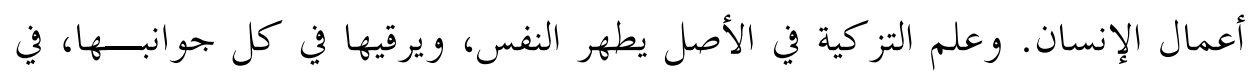

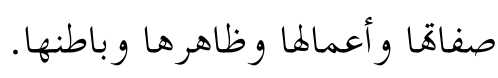

كما شكلت الانحر افات التي دخلت علم التز كية حاجزاً دون طلب علم التزكيــة الصحيح الشرعي، فنَفَرَ كثير من الناس من التزكية جملة، خوف الوقوع فيما دخهـل على علم التز كية من أخطاء و باطل و انحراف.

ومن أعظم الأخطاء التي أصابت علم التزكية: الادعاء بأنه أذواق لا علاقة للعقل

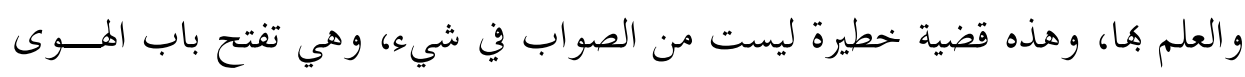

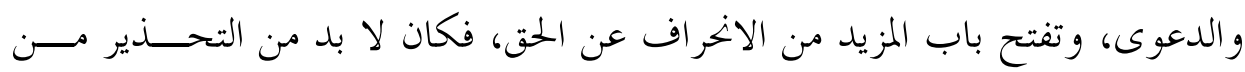
ذلك، وبيان مدى ارتباط العقل ونتائجه الفكرية بسائر أمور التزكية.

وعلم التز كية حينما ابتعد عن العقل و المنطق الصحيح الســليم الشـــرعي، فَتِـــد الضو ابط و القواعد التي تحفظه عن الاخر اف و تسدد مسيرته، فلا بد من بيان ارتبــــاط 
السلوكك والتز كية في كل مر احلها، وأطو ارها، وأعمالها، وأحو الها، وتمر اتهــا، بالعقــل والفكر الصحيح، والحقائق المعقولة.

وأهم المعقولات التي يدر كها العقل هي التي تسمى العقائد، وتســمى الحقـــائق،

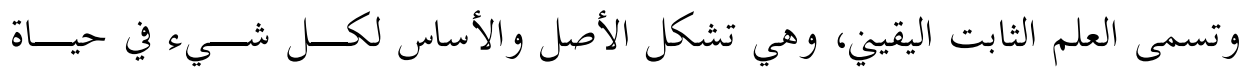

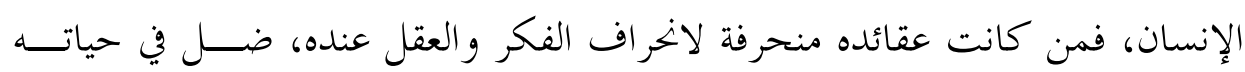

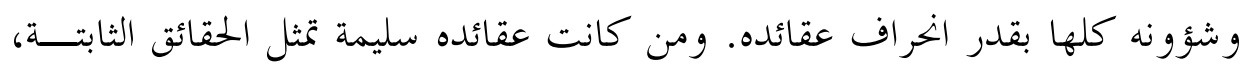

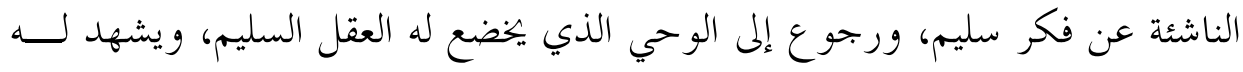

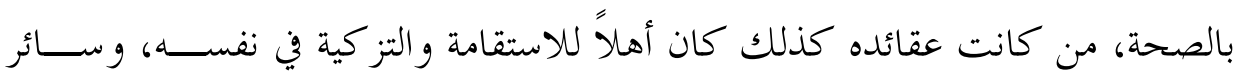
شؤونه.

وليس مقصودنا حينما نتكلم عن النظر العقلي أن نتحدث عن ذات العقل، وإنــــ تهـ

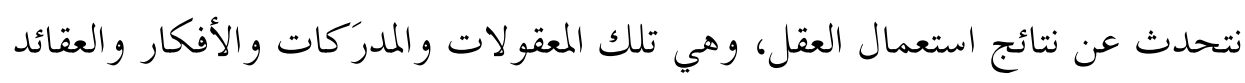
والحقائق التي يدر كها العقل وينتجها بفكره و ونظره.

ولا يجوز أن يتوهم من عنوان البحث أن النظر العقلي حاكم على الشرع، ولا أنه غير الشرع الصادر عن الوحي، وإنما من المقررات الثابتة عند جميع العقلاء والمــــؤمنين

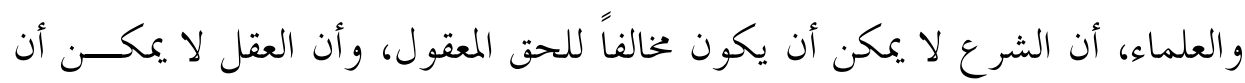

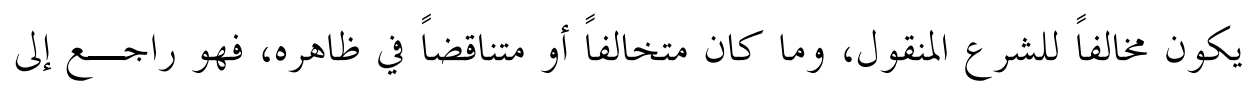

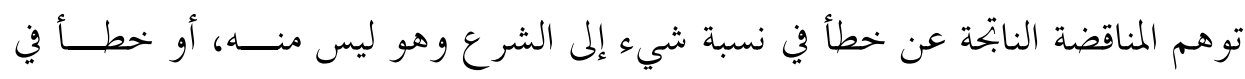

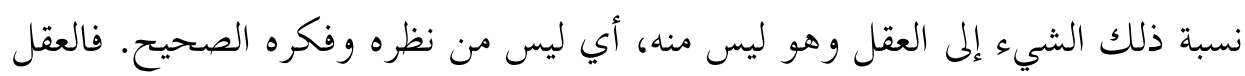

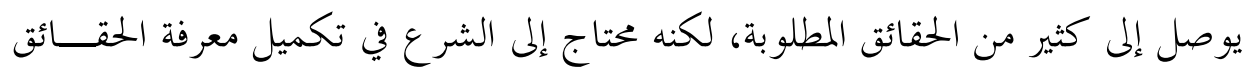

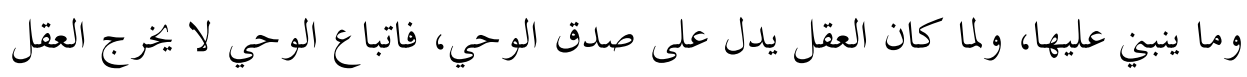
عن إدراكه. 


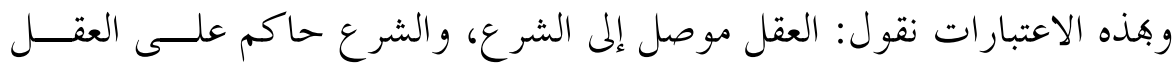

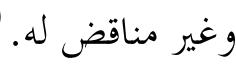

ولكن لماذا تبدأ التز كية بالنظر العقلي ونتائجه الفكرية والاعتقادية؟ لإججابة عــن

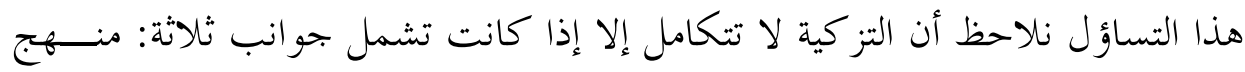

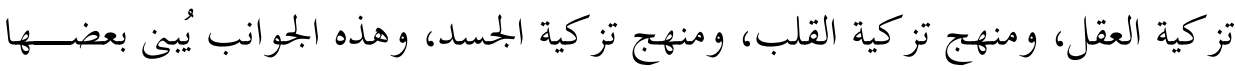

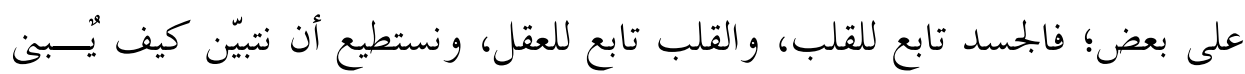
بعضها على بعض، وكيف يتولد الفعل عن القلب، وكيف يتولد ميل القلب عن إدراك

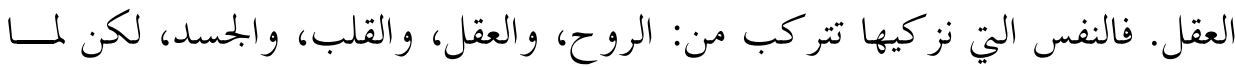

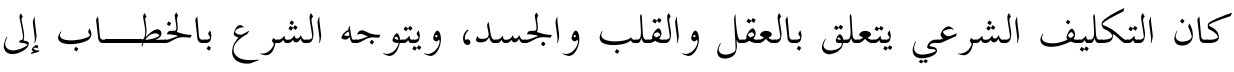

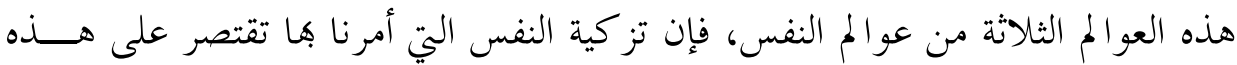

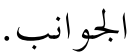

ونلاحظ أن بعض الناس يهتم بالتز كية فيما أمر الله به في حق الجســـد، وعنـــده

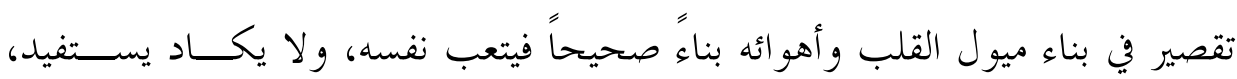

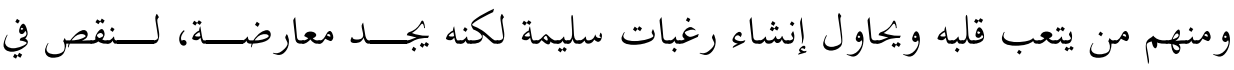

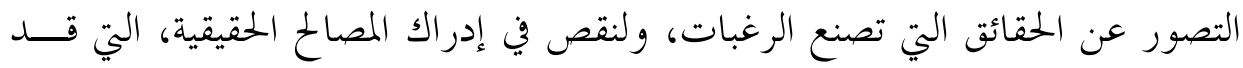

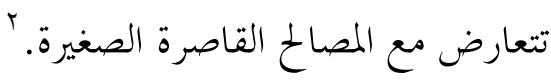

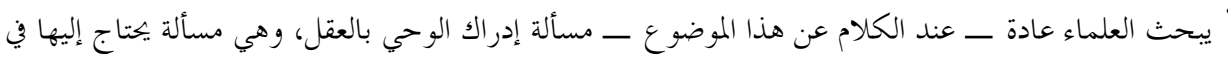

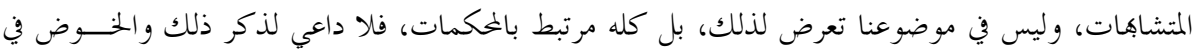

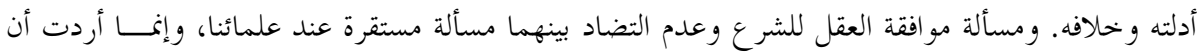

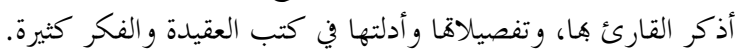

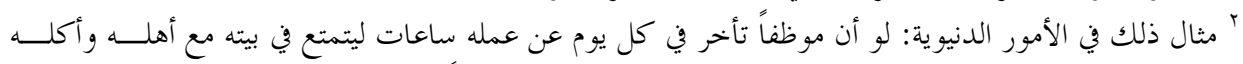

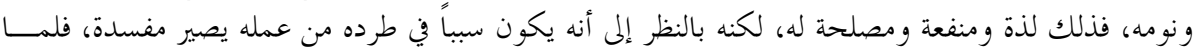

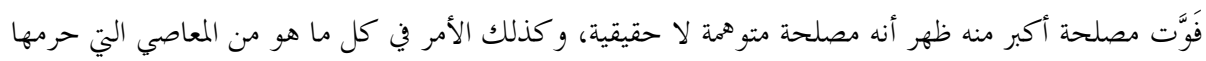

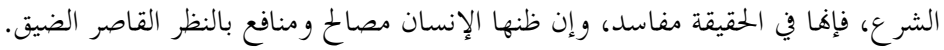




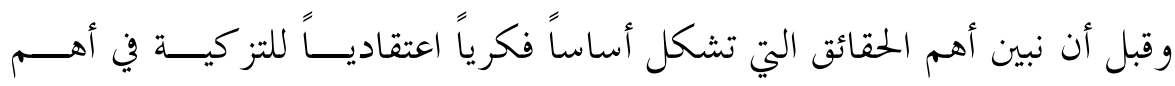

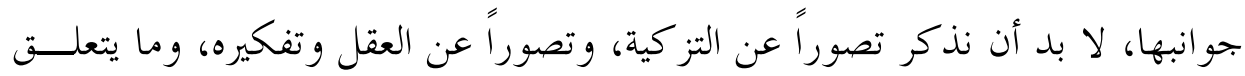

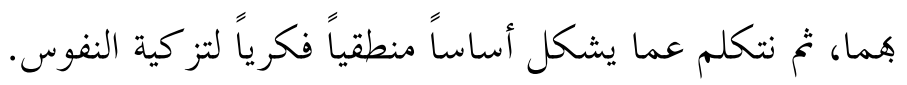

\section{أولاً: معنى تز كية النفس وأهميتها وأثرها على البجتمع}

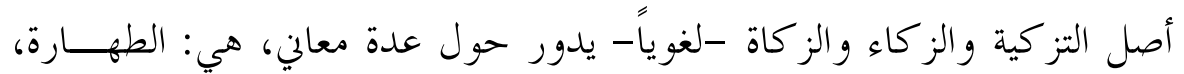

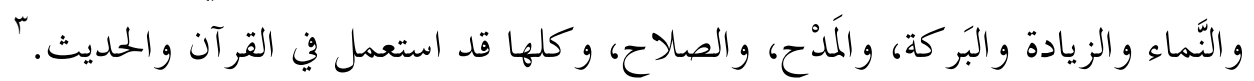

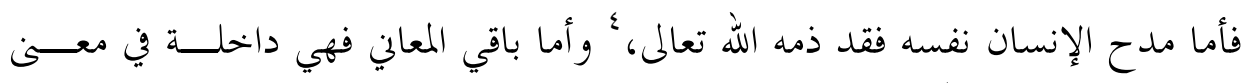

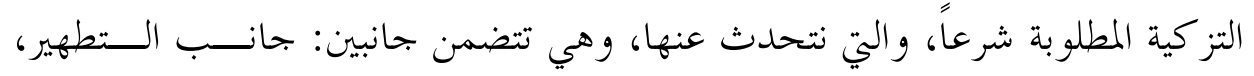
وجانب النماء و الزيادة، و كلاهما عامل في صلاح الإنسان.

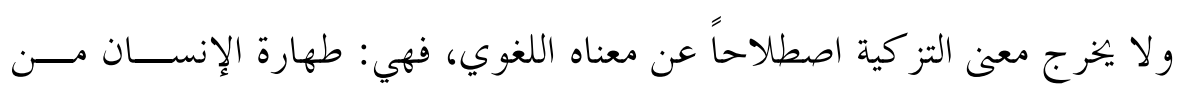

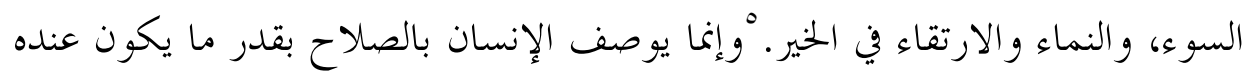

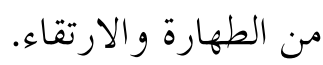

وهذا التعريف هو وصف لحقيقة التز كية من حيث هي، وتطلق التزكية ويراد ها

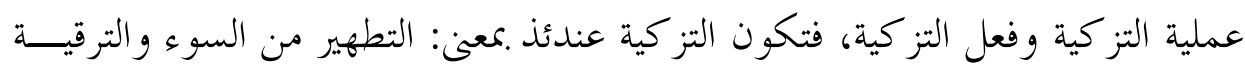

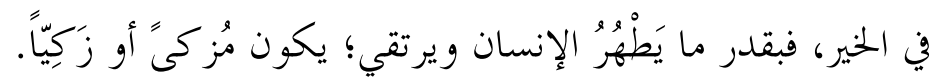

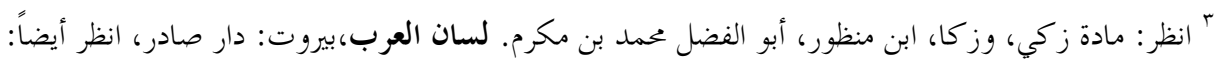

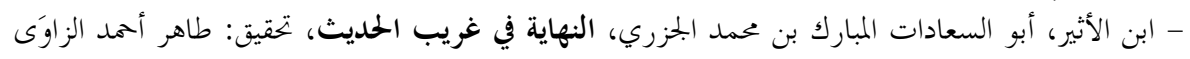

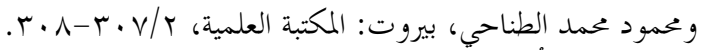

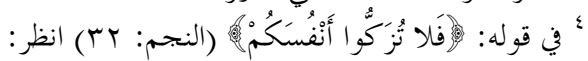

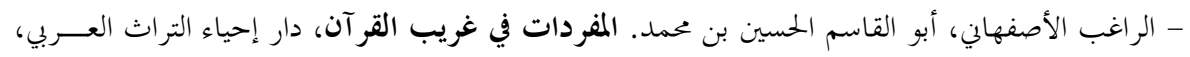

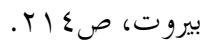

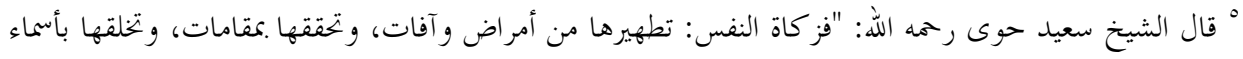

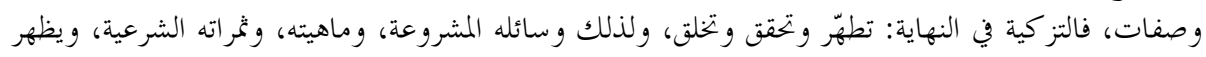

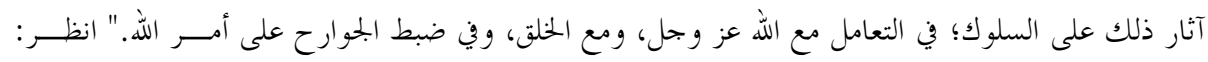

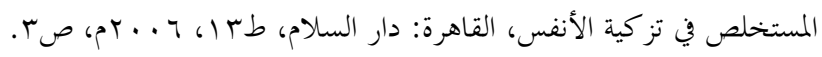


وطهارة الإنسان من السوء تشمل: طهارة عمله وقوله، وظاهره و باطنه، و نفســهـ

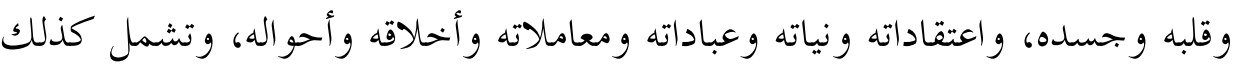
الفرد و المحتمع، وترقية الإنسان في الخير. وحيثما ذكرت التزكية في القرآن الكريم فهي شاملة لمذين المعنيين: التطهير و الترقية، كما بيّن ذلك كثير من المفسرين.

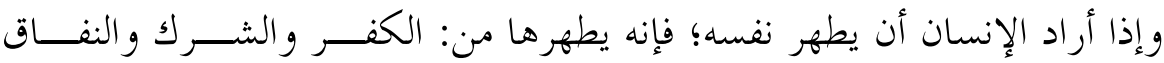
و الرياء، ومن أمر اض القلوب، ومن المعصية كبيرها وصغيرها، ومن البدع و الشــــهات و الشهوات، ومن الأخحلاق المذمومة.

وإذا أراد الإنسان أن يرقّي نفسه؛ فإنه يرقيها بالإيمان واليقين، وبالسريرة الصادقة،

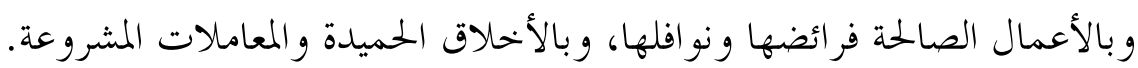
وقد جاءت الشريعة الإسلامية لتعطي الإنسان الخير كله في الدنيا والآخرة، فبــيّن الله للعبد العلمَ الصحيح، وبيّن العمل المطلوب، وهيّأ وسائل ذلك، وبعث الرسل، وهيّأ وهئ

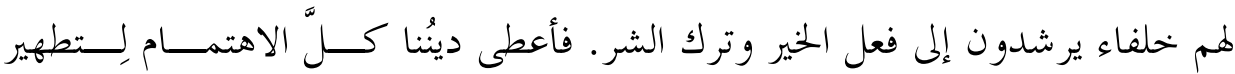

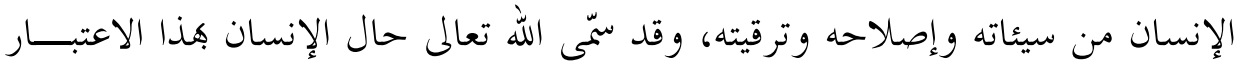

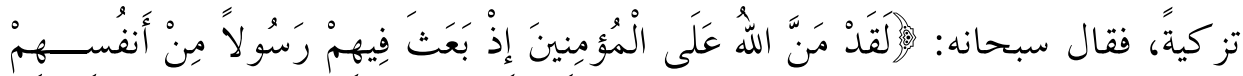

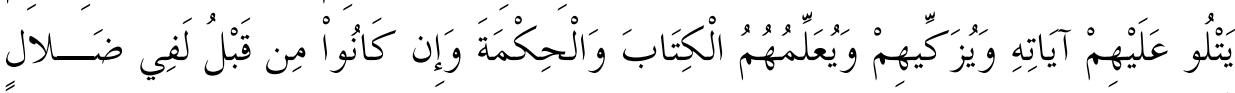
مُبين.

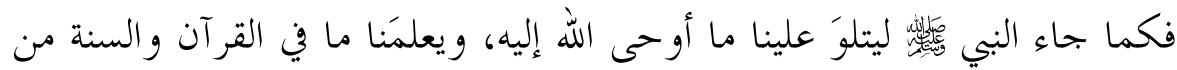
علم و حكمة وأحكام؛ فقد جعل الله من وظيفته تز كية النفوس.

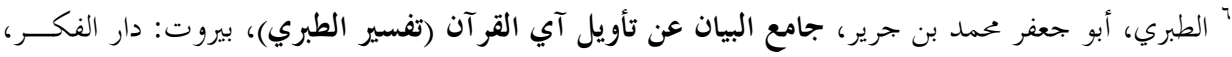

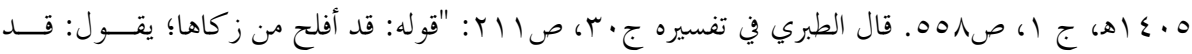

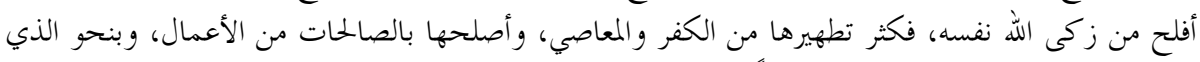
قلنا في ذلك قال أهل التأويل". انظر أيضاً:

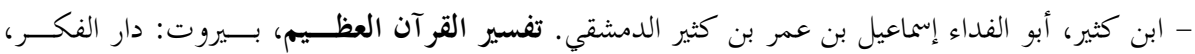


وبيّن الله تعالى أن فلاح الإنسان وبنحاته متوقفة على التز كية، فقال سبحانها

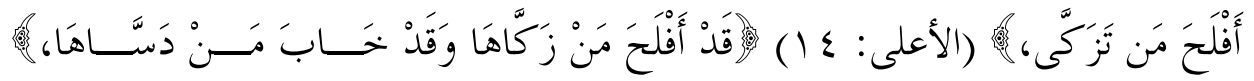

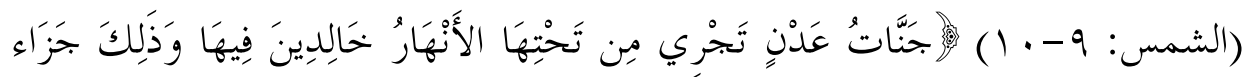

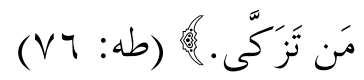

وبما ينبغي أن تحدثه التز كية في المسلم، أن تحول الاعتقاد من كونـــه اعتقـــاداً في

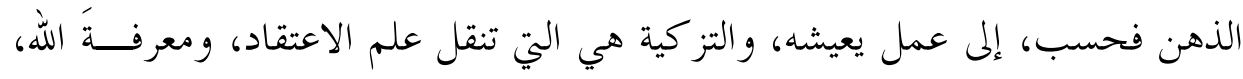

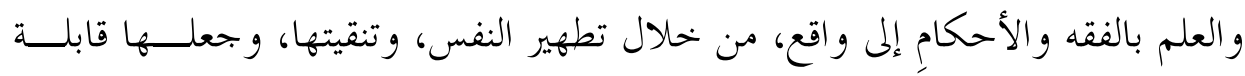

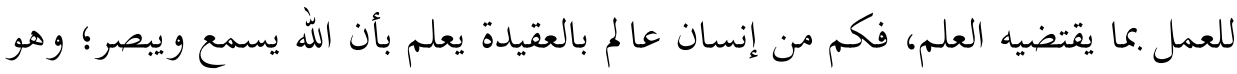

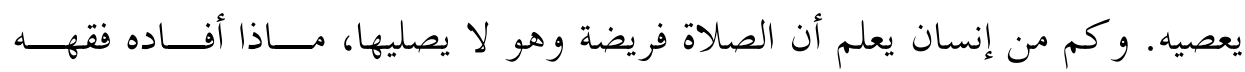
وعلمه؟ فلا بدّ من تطهير للنفس لتصل إلى الانتفاع من العقيدة والفقه.

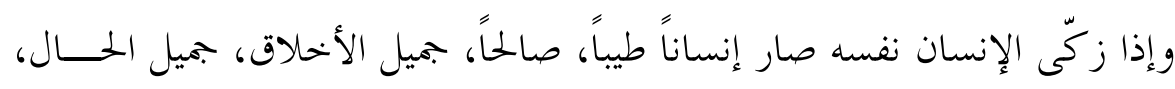

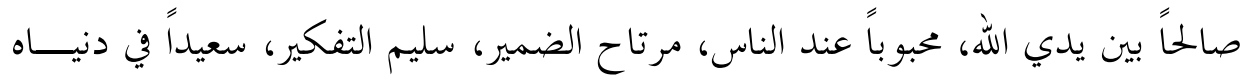

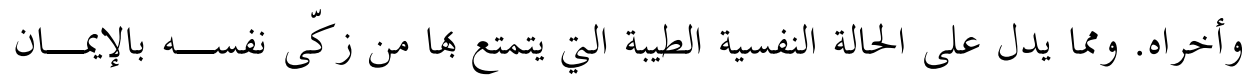

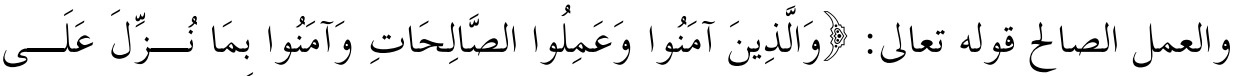

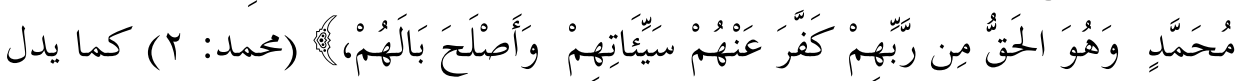

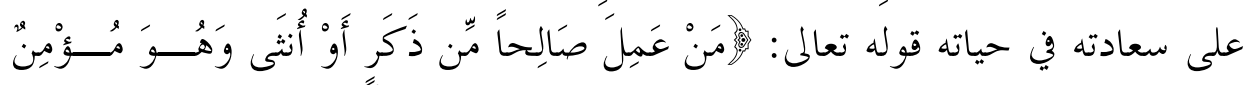

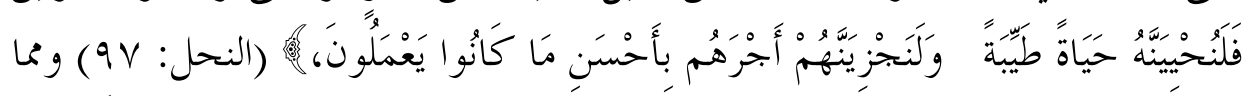

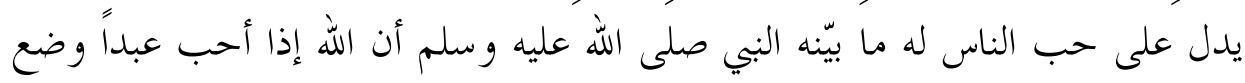

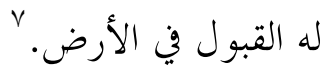

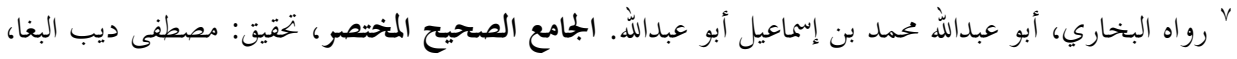

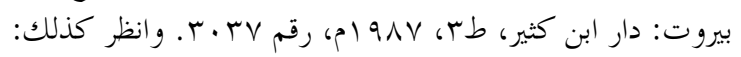

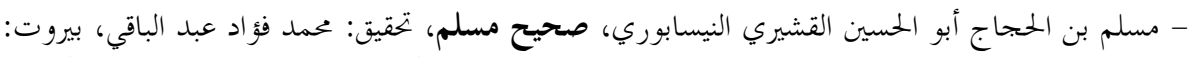

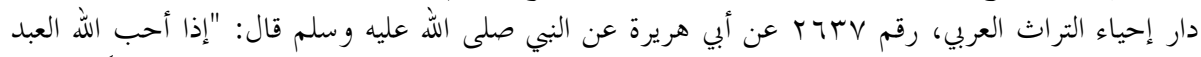

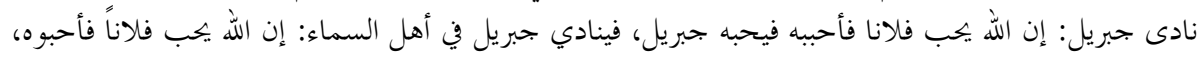

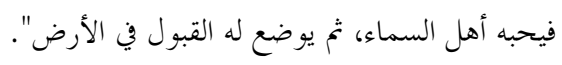




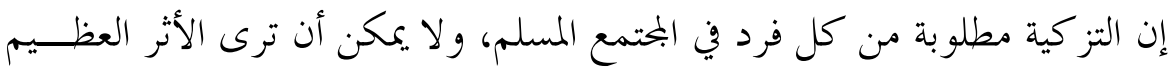

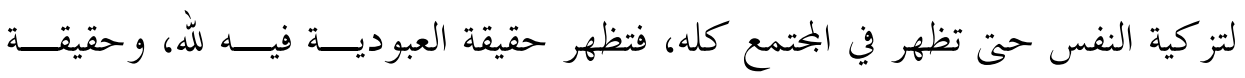

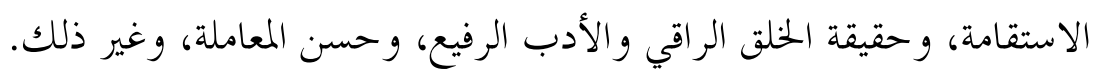

و التز كية إذا وجدت في البحتمع المسلم؛ فإذها وحدها من أعظم وسائل الدعوة إلى إلى

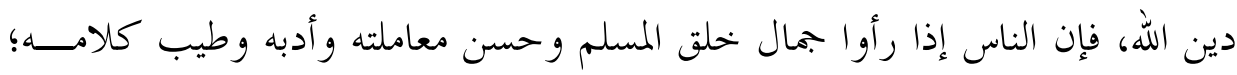

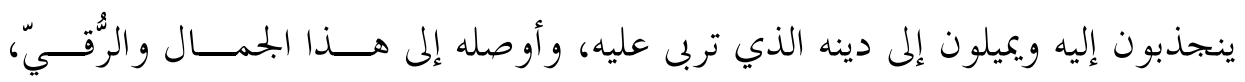

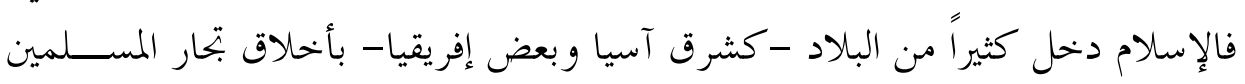

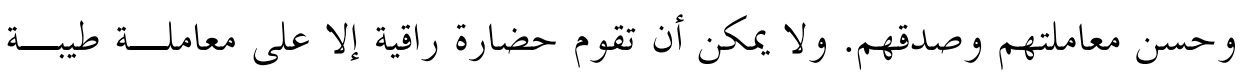

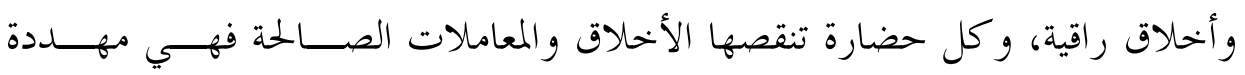

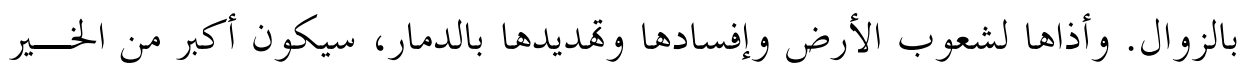
الذي تقدمه أو تسعد به البشرية.

ثانياً: معنى العقل ووظيفته وتز كيته

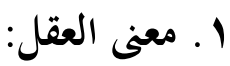

لما كان هذا البحث يتناول قضية التز كية، وأها ينبغي أن ترجع إلى العقل وتفكيره

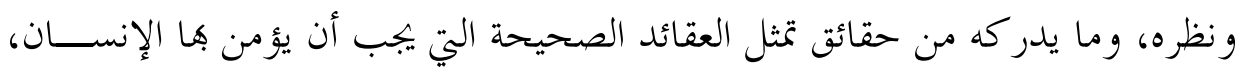

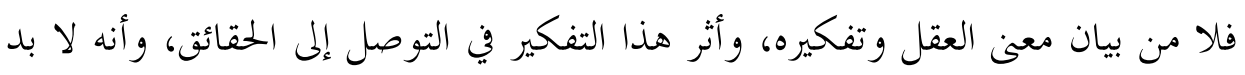
أن نزكي العقل كما نحرص على تز كية غيره، فهو أولى بالتز كية و التطهير و الترقية؛ لأنه

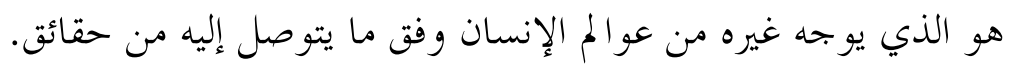

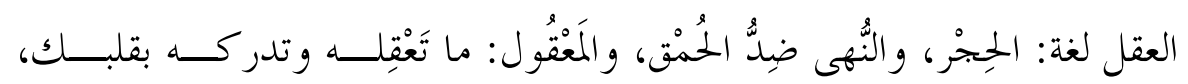

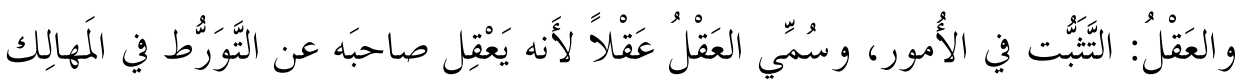


أَي يَحْبِسه، وعَقَلَ الشَيَ يَعْقِلُه عَقْلاً: فَهِمه، ^ و العقل: المنع، لمنعه صاحبه من العدول عن سواء السبيل.

يفهم من هذه المعاني للعقل أنه به تدرك الأمور وتفهم، وبه تميز الأمور، فيُعَفَ به

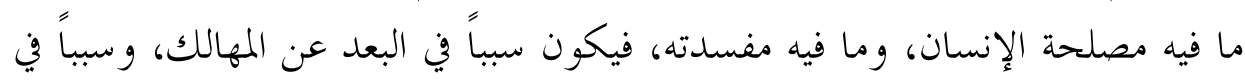
البحث عن المنافع.

أما من الناحية الاصطلاحية، فقد أورد العلماء للعقل تعريفات ككـثيرة، بعضـــها يجعل العقل هو الروح؛ لأن العقل لا إدراك له بلا روح، و بعضها يجعله هو القلب؛ لأن

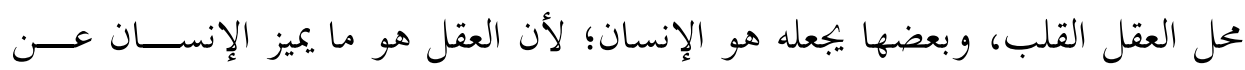

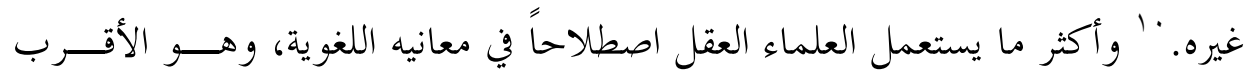
لتعريف حقيقته.

و الذي أرجحه جمعاً بين معاني التعريفات التي اطّلعت عليها، أن يعـــف العقــل بأنه: هو اللطيفة التي يدرك بها الإنسان العلوم و المعاني والأشياء، وبها يميز بـــن الحـــق

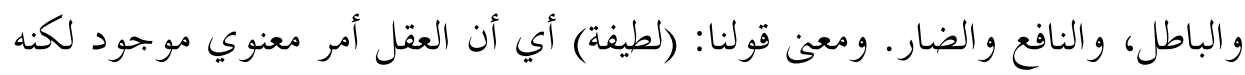
غير حسي، وإن ارتبط بموضع حسي من الجسد.

ذكرت لفظة العقل ومشتقاها في القر آن الكريم و السُّنة الشريفة كثيراً، وغالباً مــــا تطلق على أحد أمور ثلاثة: العقل: من حيث هو آلة لإدراك العلم، والعقل: من حيث

^ انظر : ابن منظور، لسان العرب، مرجع سابق، مادة عقل، ومثما قاله أيضاً: وقيل: العَقْلُ هو التمييز الذي به يه يتميز

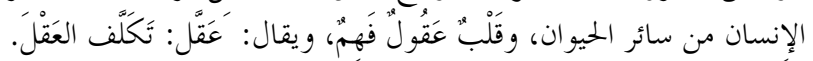

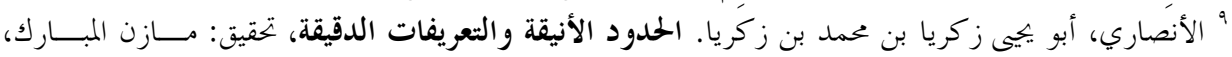

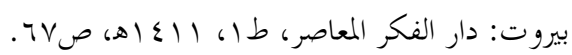

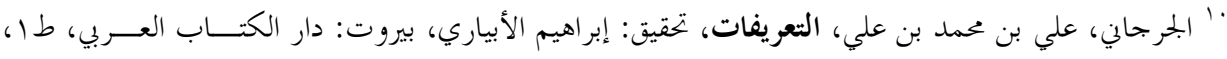

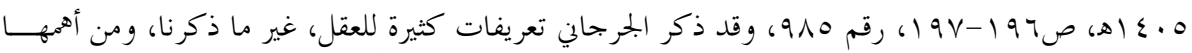

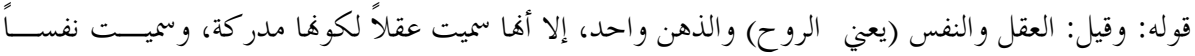

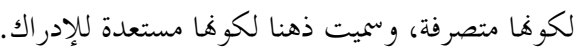


عملية الإدراك والتعقل التي توصل لإدراك العلوم، والعقل: مععنى العلم الذي يســتفاد

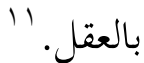

ويأتي العقل .معنى الشيء الذي به يعقل الإنسان، ويدرك العلم والمعاني والحقائق؛

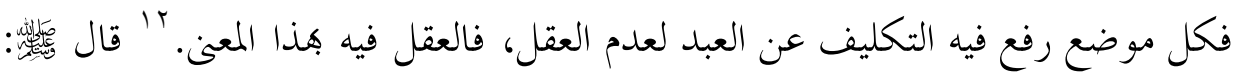

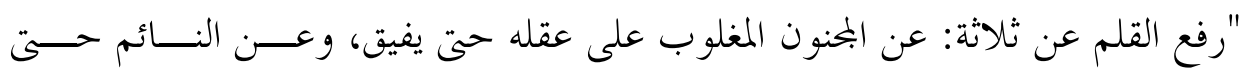

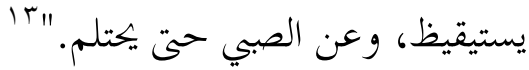

ويأتي العقل .معنى استعمال العقل في عملية التعقل والفهم والإدراك و التمييز؛ فعن

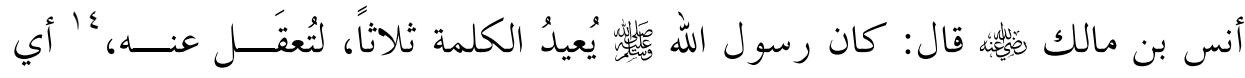

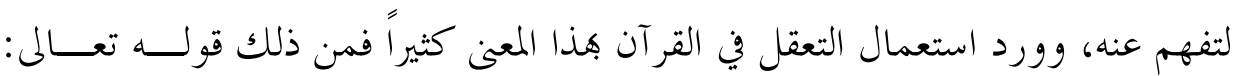

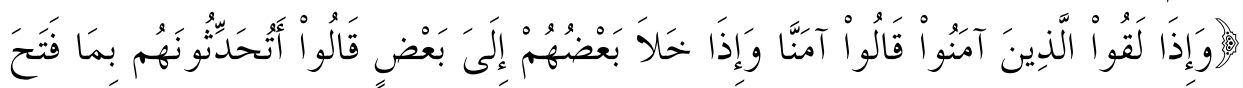

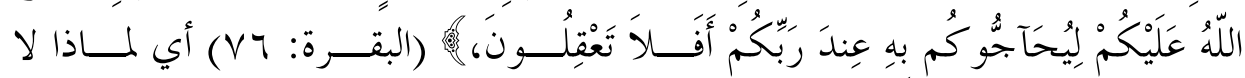
تستعملون عقو لكم، لتعلمو ا ما يجب عليكم أن تعلموه.

"ا الراغب، المفردات في غريب القر آن، مرجع سابق، ص إ؟ب، عن ذلك فقال: "العقل: يقال للقوة المتهيئة لقبول

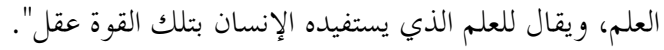

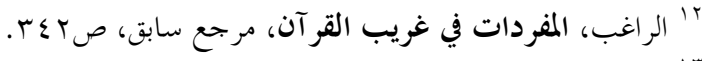

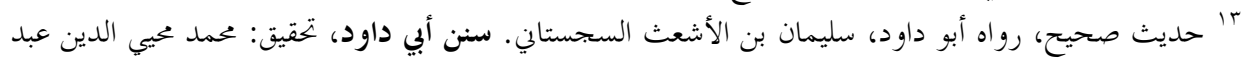

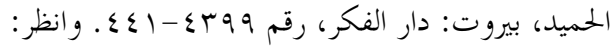

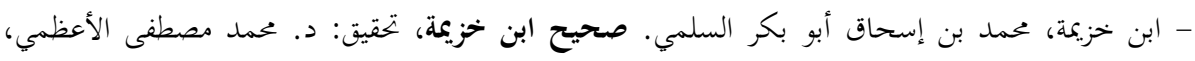

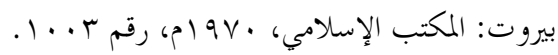

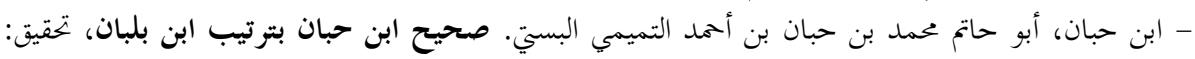

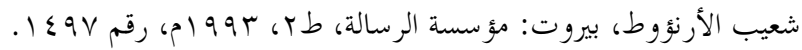

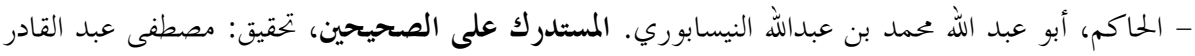

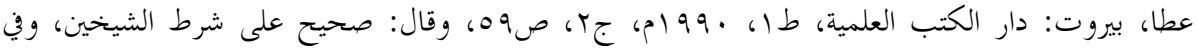

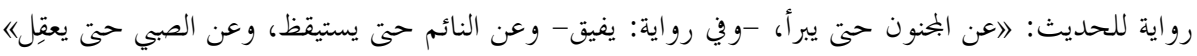

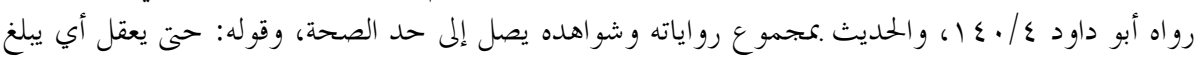

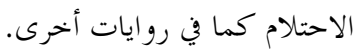

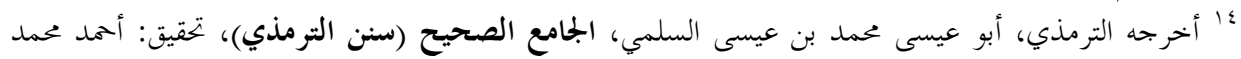

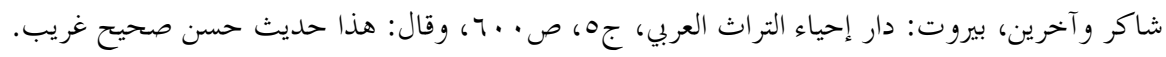




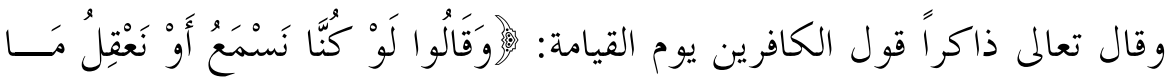

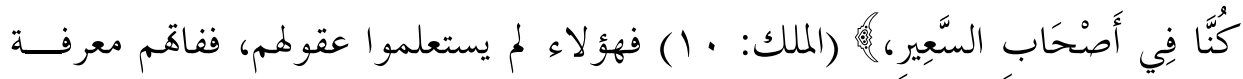
الحق، و نتج عن ذلك أن تكون حياقم وأهو اؤهم و أعمالهم كلها خاطئة خاسرة.

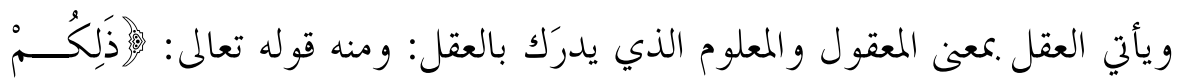

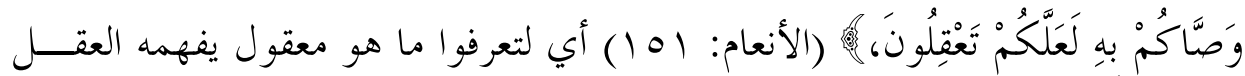

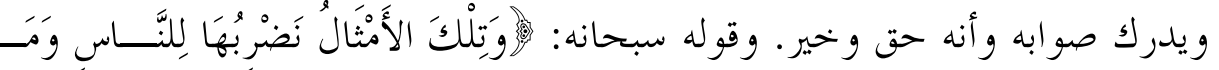

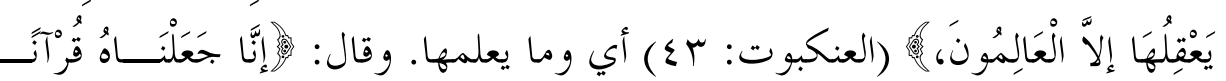

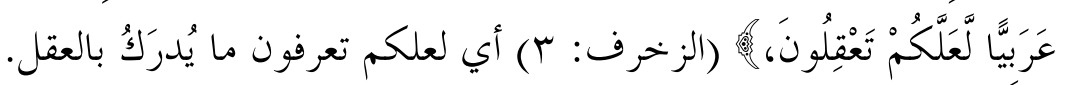

و كل موضع ذم الله فيه الكفار بعدم العقل فالمقصود فيه عدم علمهم لما يجـــبـ أن

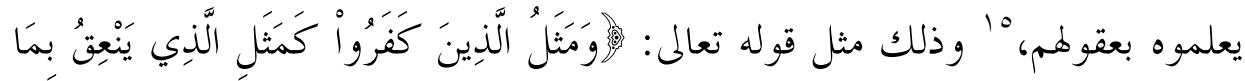

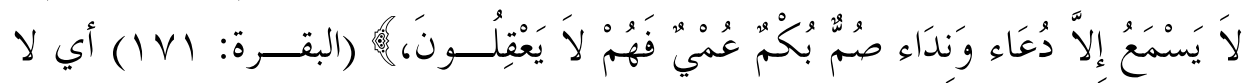
يعرفون ما يجب أن يعرفوه بعقوهم، وذلك لأفم لا يستعملون العقل. و القر آن يستعمل العقل هذذا المعنى كثيراً، وينفي وجوده عن الكافرين، و لا ينبغـي أن يُخَنَّ أنه ينفي عنهم العقل الذي به التكليف، لذلك قال سعيد حــــى رحمـــهـ الله: "و يطلق العقل في الشريعة على شيئين: أولاً: على ما هو مناط فهم الخطاب، وإذا و جدد

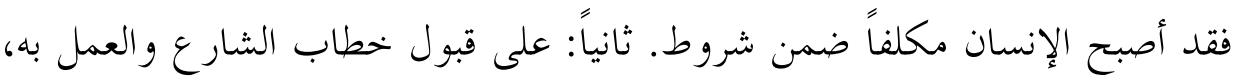

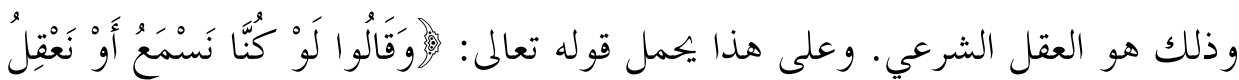

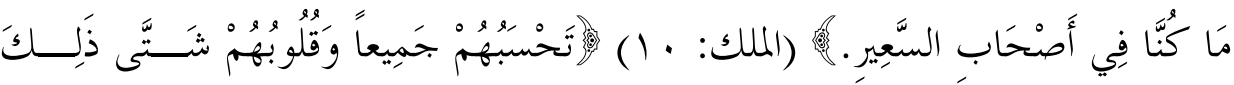

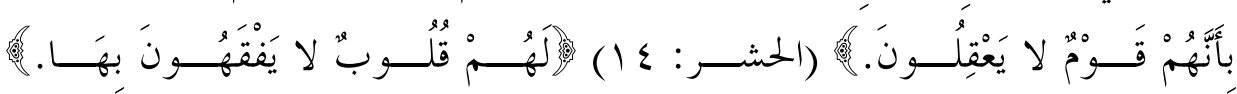

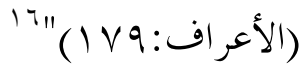

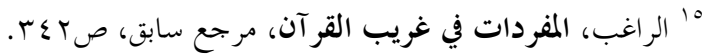

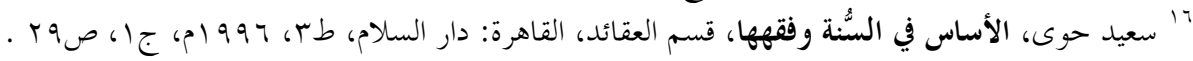




\section{Y. المهمة الأساسية للعقل هي التَّكُّر أو التفكر للوصول إلى العلم:}

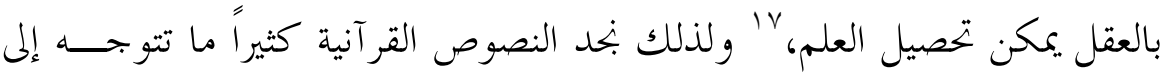

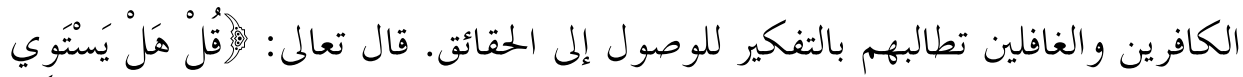

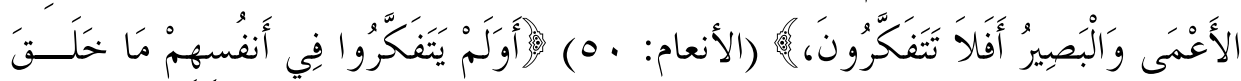

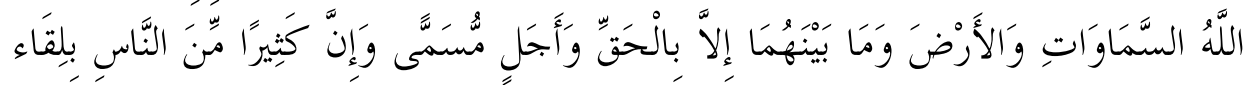

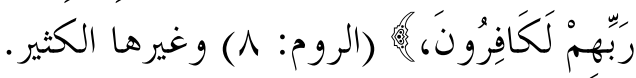

والتَّكٌُُ هو نظر العقل في الأدلة بترتيب أمور معلومة في الذهن ليصل من خحلالها

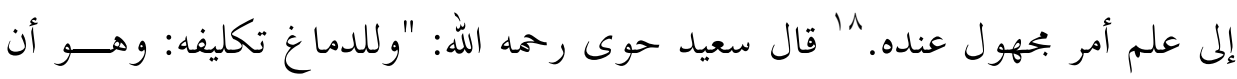

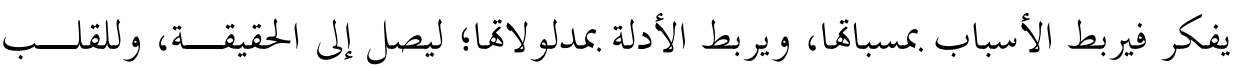
تكليفه: وهو أن يقبل الإسلام الذي أوصل إليه العقل، وأن يستنير بنور الإسلام."

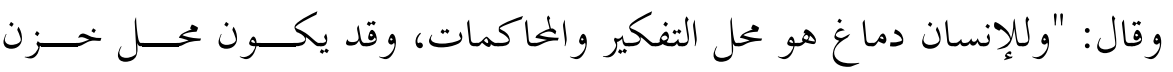

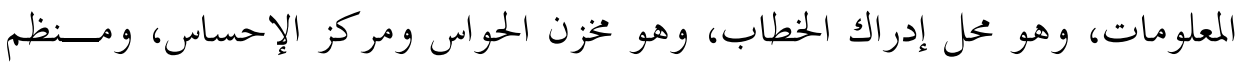

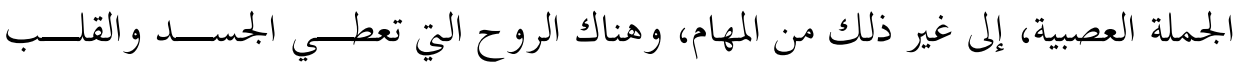

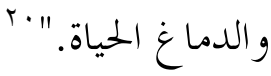

وقال: "والعقل هو مناط التكليف، وهو الجههة التي يدرك فيها الإنســـان فحــــى

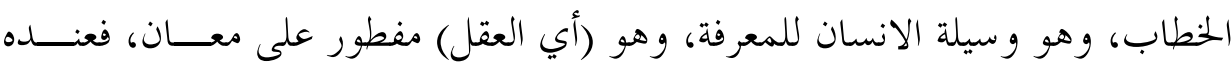

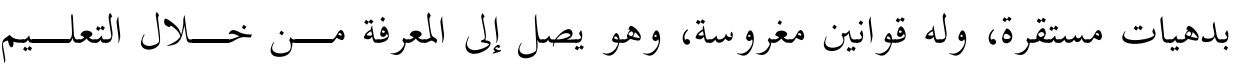

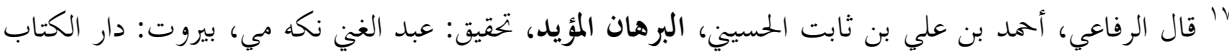

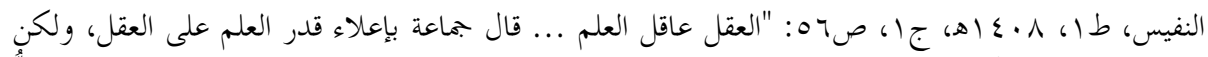

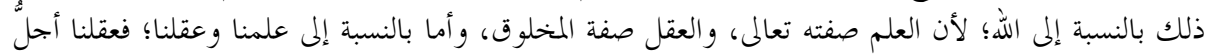

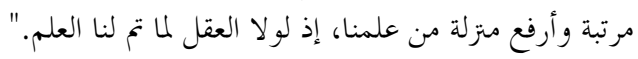

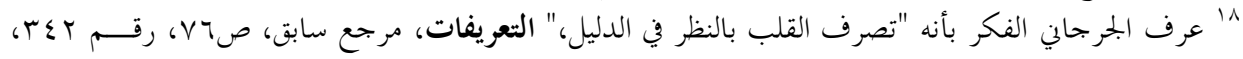

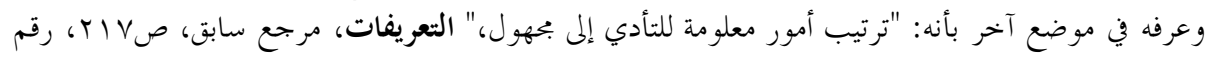


والاستقراء أو الاستتناج، ومن ههنا وجد علم المنطق الاستقر ائي والاستنتاجي، فــأن

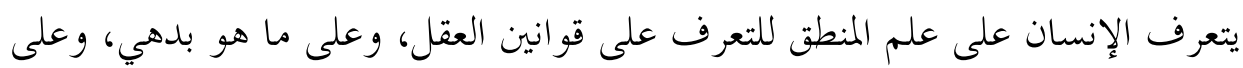

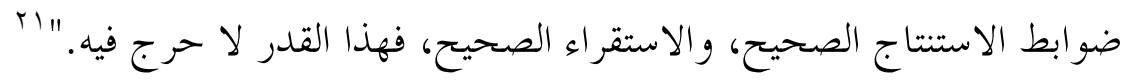

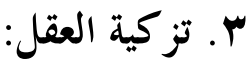

تدل النصوص على أن طريق الهداية يبدأ من القلب، "ألا وإن في الجسد مضغة إذا

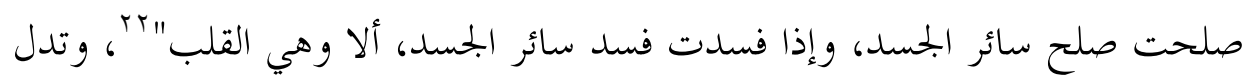

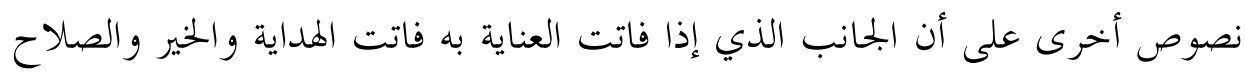

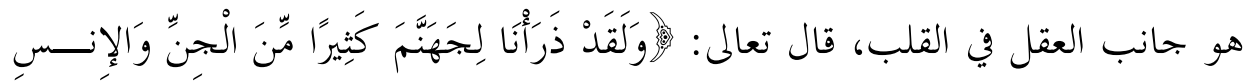

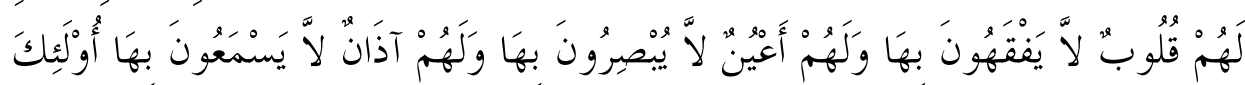

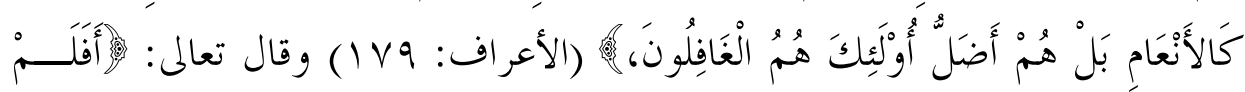

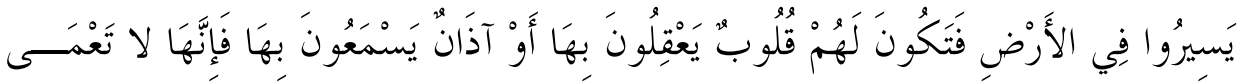

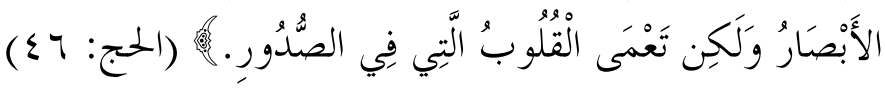
إن استعمال العقل على وجهه الصحيح، والاستفادة منه في الوصول إلى الصواب

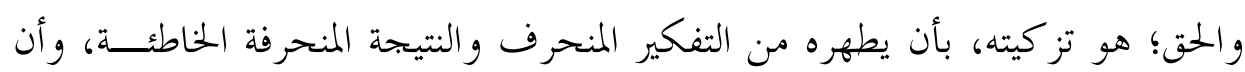
يلازم استعماله في التوصل إلى الحقائق والانتفاع منها. وتز كية العقل تكون باستعماله؛ فمن خلق سوياً غير بجنون ولا غختــل في عقلــه،

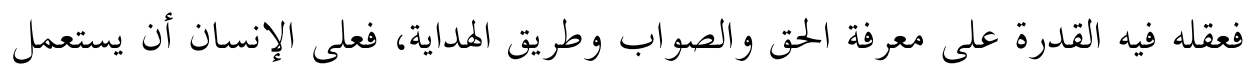

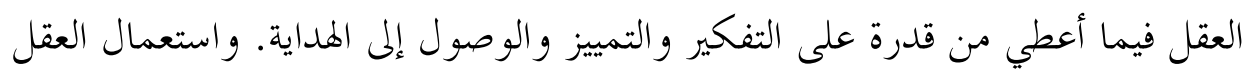

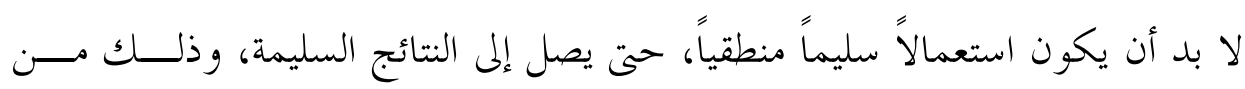

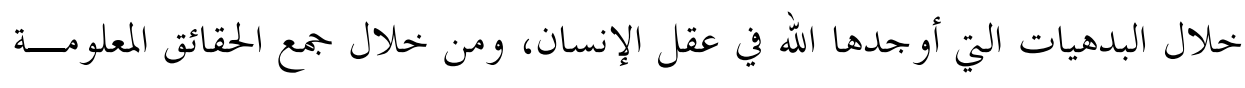


الثابتة ثم استنباط نتيجة صحيحة منها، وباستعمال براهين وحجج وأدلة سليمة تـــل

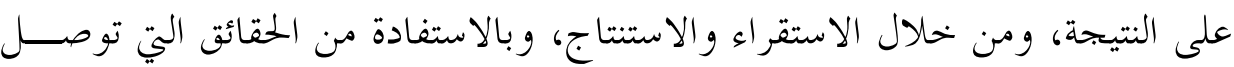

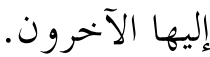

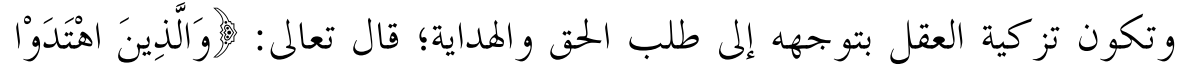

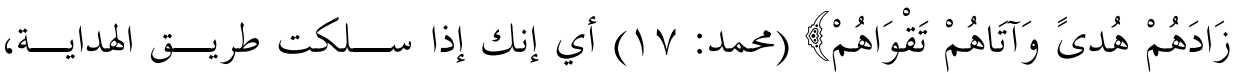

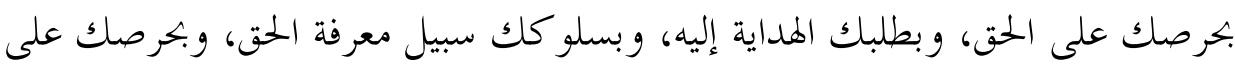

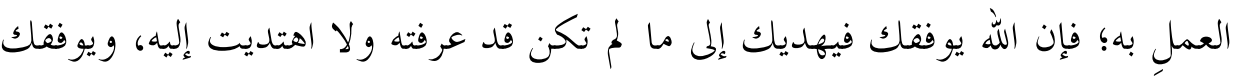

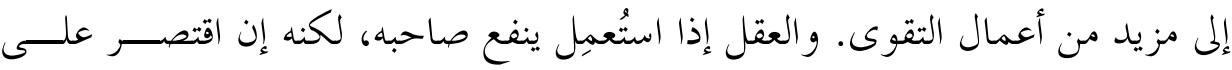

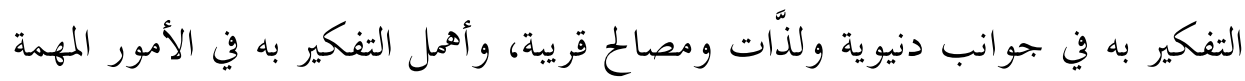

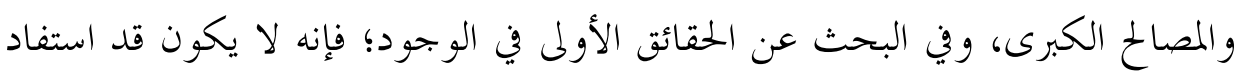

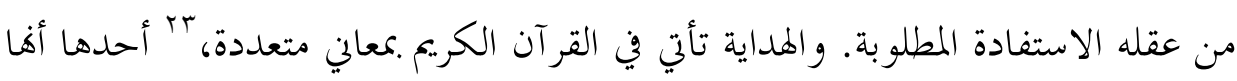

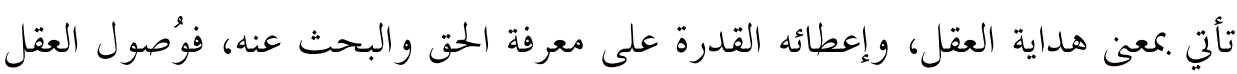
إلى الحقائق هداية.

ورغم أن الحقائق الكبرى يمكن معرفة أكثرها وأهمها بالعقل، فالله تعالى لم يتركنا

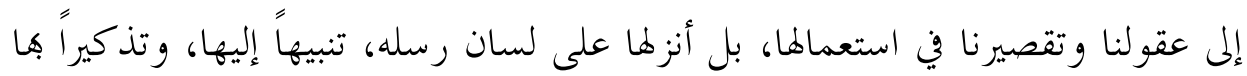

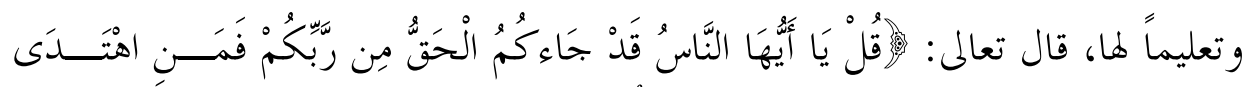

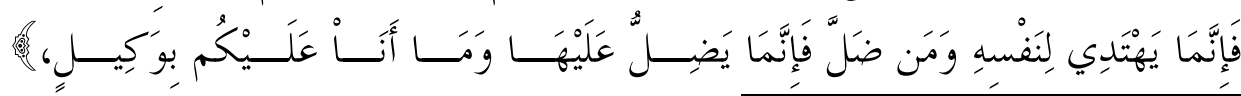

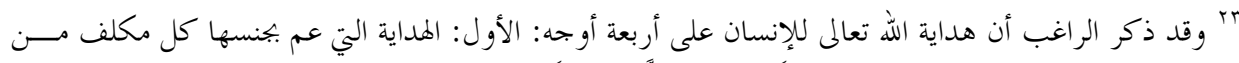

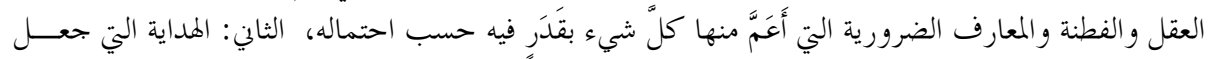

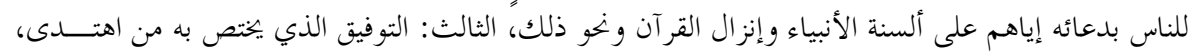

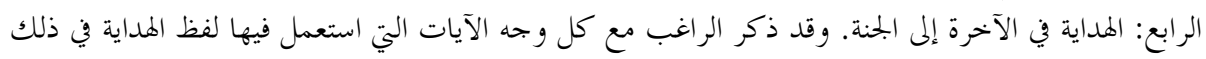

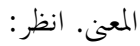

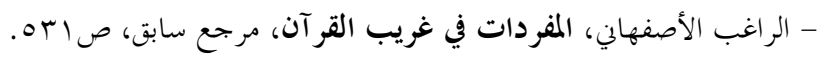

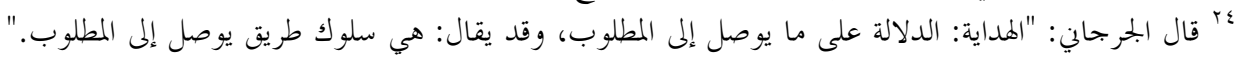

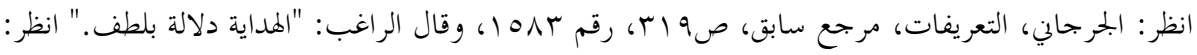
المفردات في غريب القرآن، مرجع سابق، صمانىه صنه. 
(يونس:1 • (1) فما على الإنسان إلا أن ينظر ليجد الحق في هـــــه الشــــيعة، ويـــــى

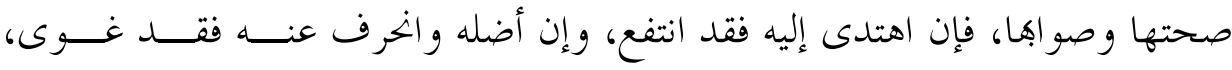
وأخطأ الطريق السليم.

والحقائق الكبرى التي يجب أن يهتدي إليها الإنسان ويبحث عنها هـــي أركــان

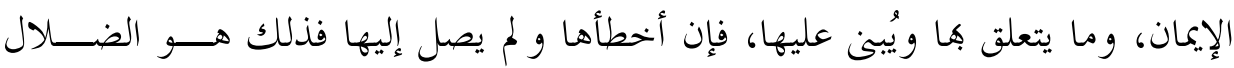

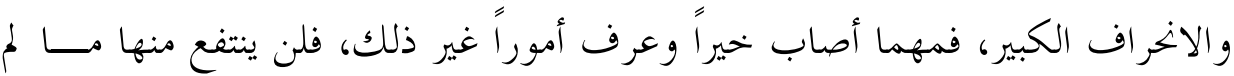

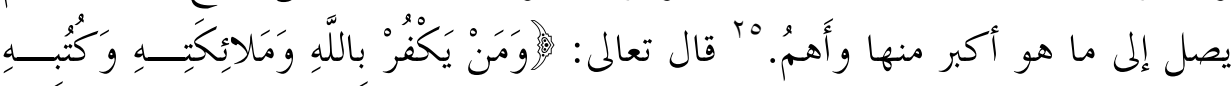

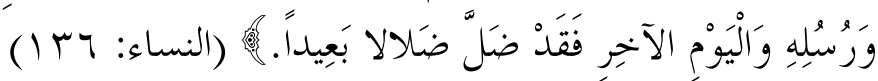

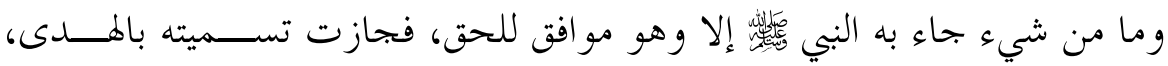

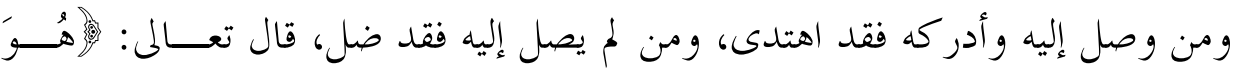

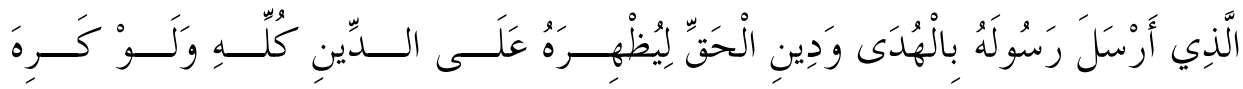

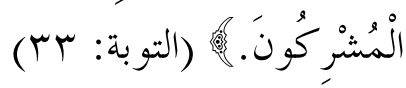

وتكون تز كية العقل كذلك بالاستفادة من العوامل المعينة للعقل في الوصــول إلى الحق؛ فقد جعل الله تعالى للإنسان وسائل ومنبهات يمكن أن تنبه العقل إلى التفكير، أو

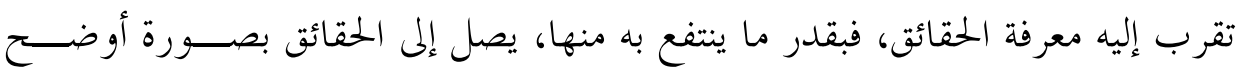
وأسرع. ومن هذه الوسائل: - نظر العقل في الآيات الكونية والآيات القرآنية، ودلالاها: فالتفكر في آيات الله التي بثها في الكون، تثير العقل وتفكيره ليهتدي إلى الحق، أي إلى معرفة الحقائق الثابتة

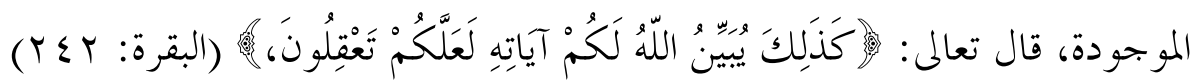

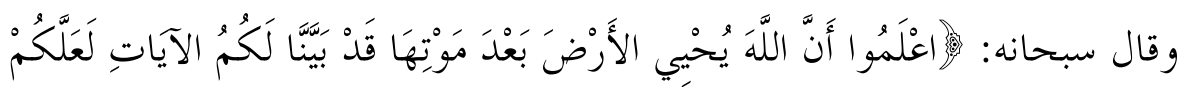

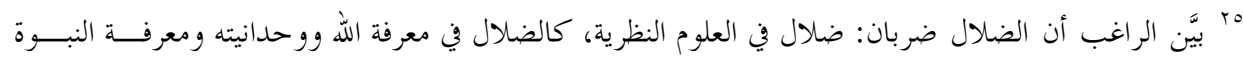

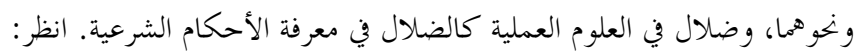

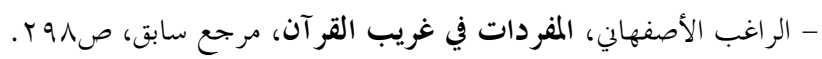




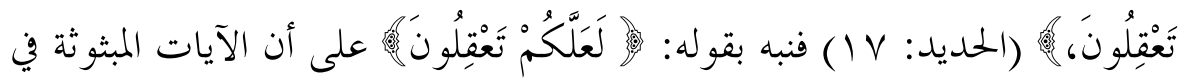

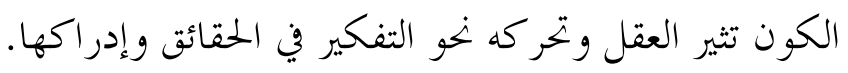

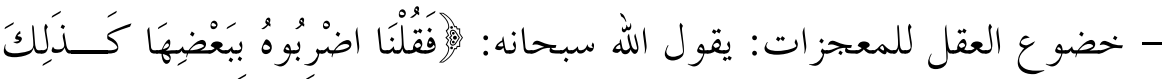

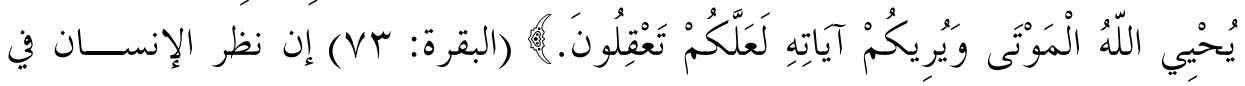

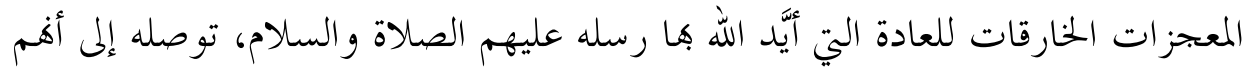
حق مرسلون من عند الله، فما أجرى على أيديهم ما لا يستطيعه الخلق جميعاً إلا ليدلنا

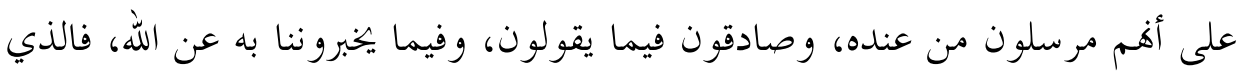

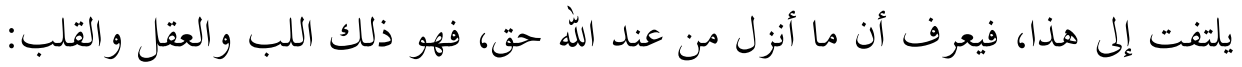

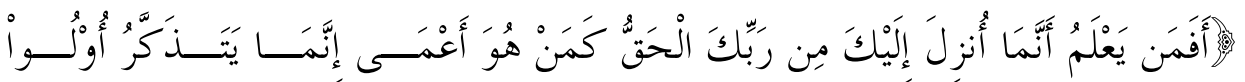

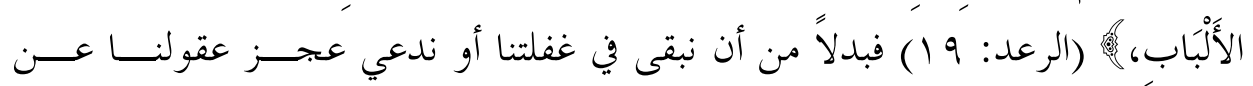

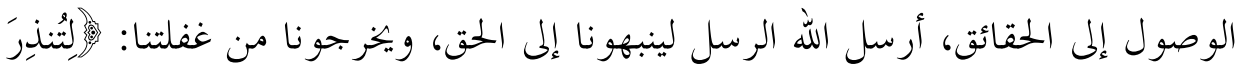

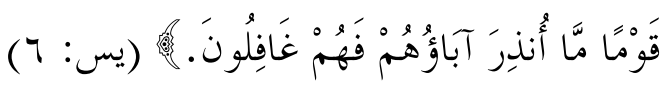

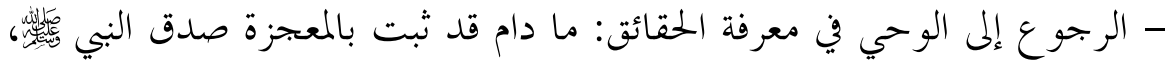

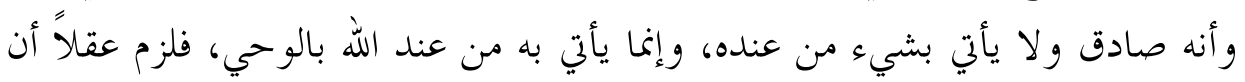

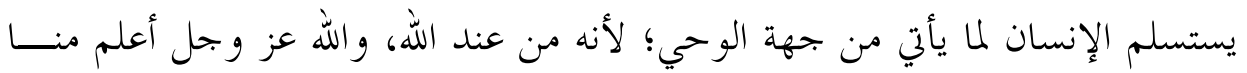

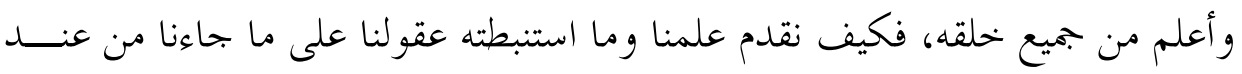

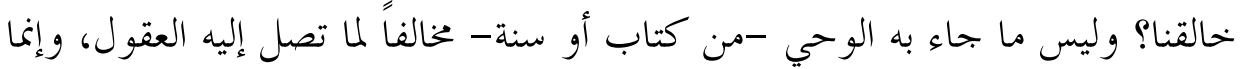

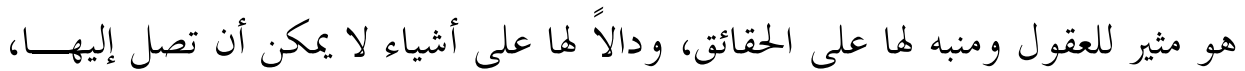

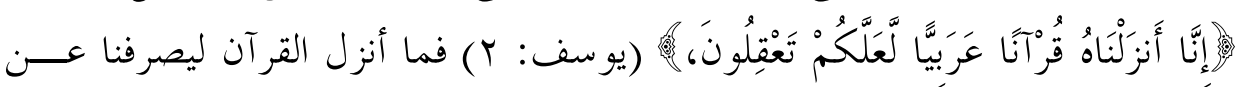

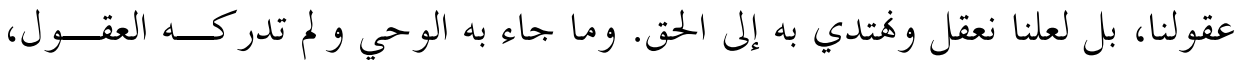

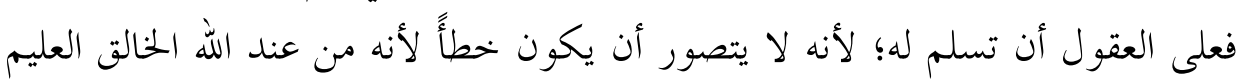


- الاستفادة ممن أخذ عن الوحي وتعلم منه: ومن أخذ عن الأنبياء وتبعهم وحمل

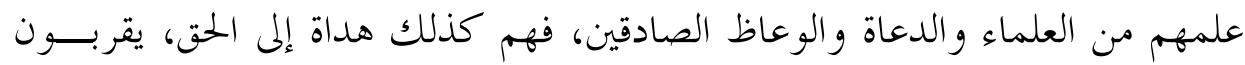

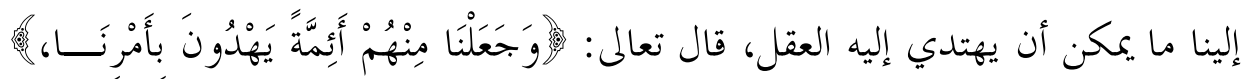

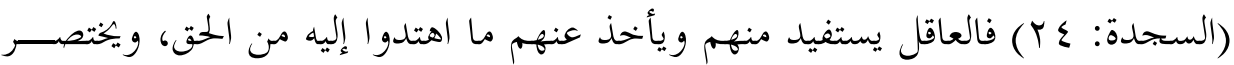

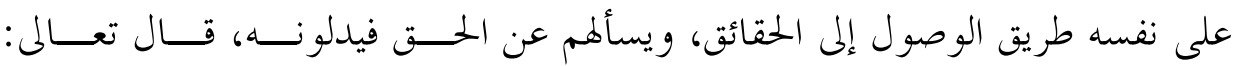

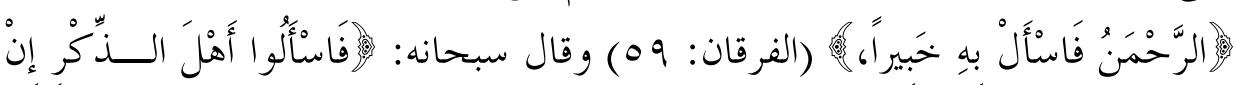

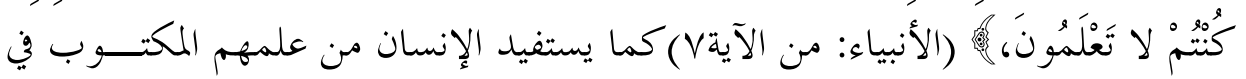
كتبهم.

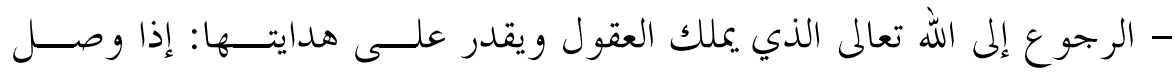

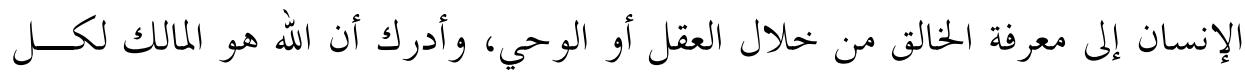

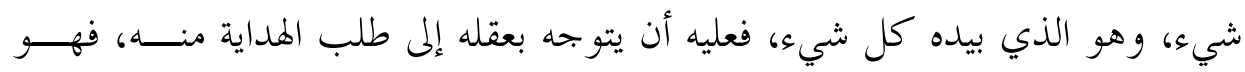

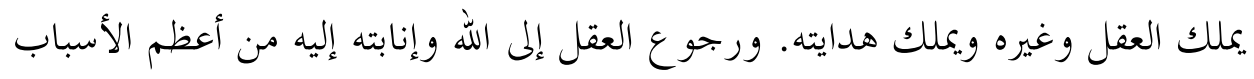

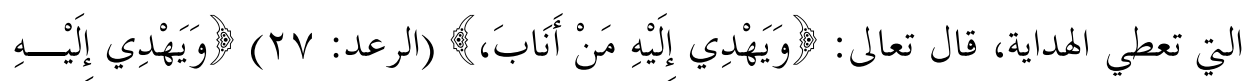

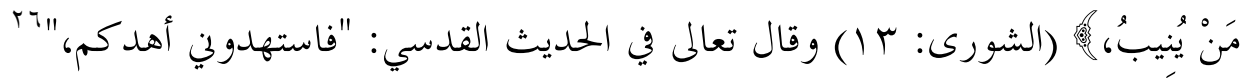
فالله تكفل همداية من يطلب الهداية منه.

- تَنَبُهُ العقلِ عند الأحداث و البلايا التي توقظ العقل: جعل الله تعــالى في هـــــا

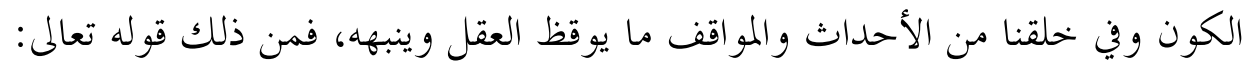

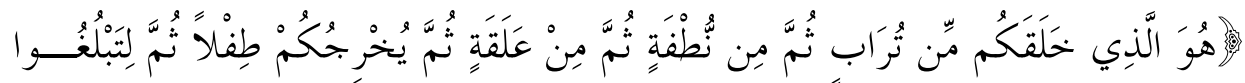

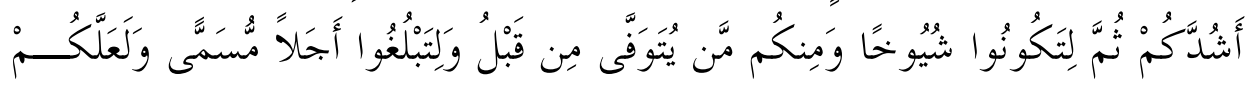

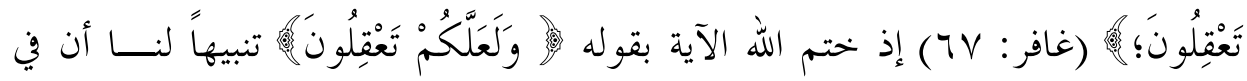
مر احل حياتنا ويف موتنا ما ينبه العقل، ويوقظ العاقل، ويلفت نظره إلى غيب يـــؤثر في لهي 
عالم الشهادة، يمكن أن تدرك العقول أثره ووجوده. و والمواقف المنبهة لعقــلـل الإنســــان و الموقظة له كثيرة، منها: موت قريب أو صديق، أو دفن ميت، أو حادث، أو مـــرض

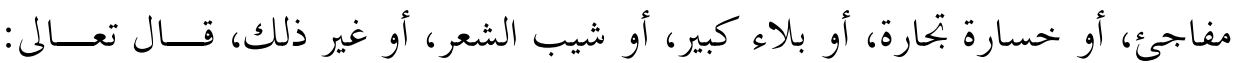

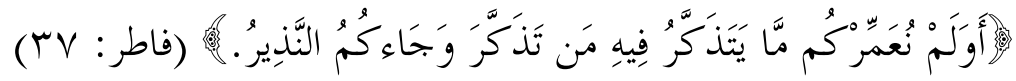

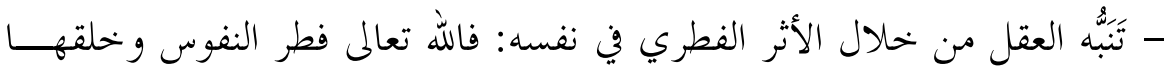
على حب الحق والميل إلى العبادة، فمن لم تتأثر فطرته بالمؤثرات الســلبية و العوامــــلـ

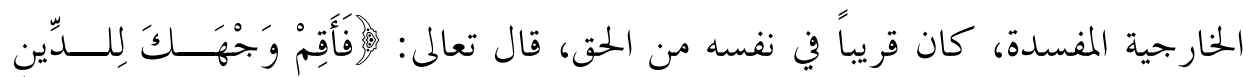

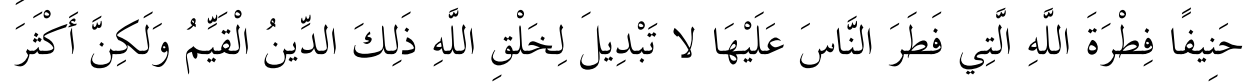

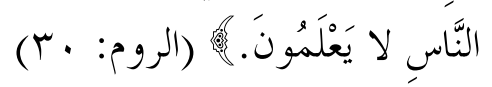

وتكون تز كية العقل بمنع الأسباب و المؤثرات التي تحول دون اســتعمال العقــل و الفكر، أو تحول دون وصول العقل إلى الحق. ومن ذلك: - عدم التكذيب بالحق ورفضه حينما يصل إليك أو تتوصل إليه؛ فالحق لا يبـــوز

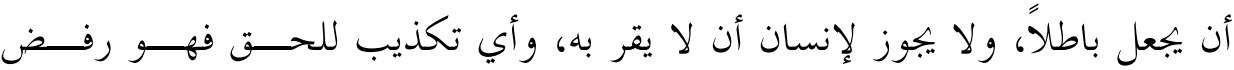

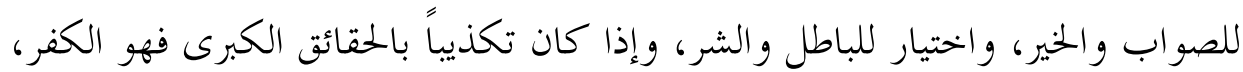

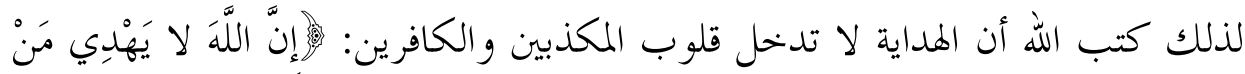
هُوَ كَاذِبعُ كَفَّارُه. - عدم رفض أي حقيقة ثابتة؛ ذلك أن الهداية تحتاج إلى رغبة في معرفــة الحـــق، وعزم على قبوله حين معرفته، فإذا تردد الإنسان في الواضحات، و لم يؤمن هها رغـــم و ضوحها وتبوها، فقد صادم عقله وتخلى عنه، وأعلن عدم الرغبة في الحق، فلا يهتدي

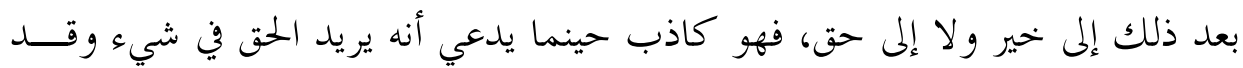
تخلى عنه فيما بان له واتضح، لذلك كتب الله تعالى أن لا يهدي من رفض الحق بعدما

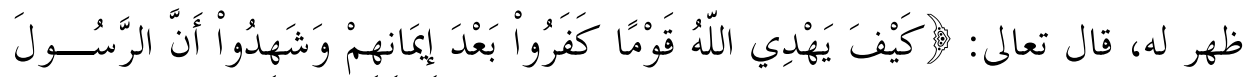

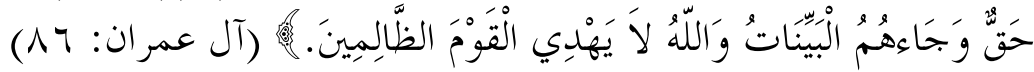


- عدم ترك العقل لقول الآخرين؛ فمن العوامل المضللة للعقل أن يعظم الإنســان

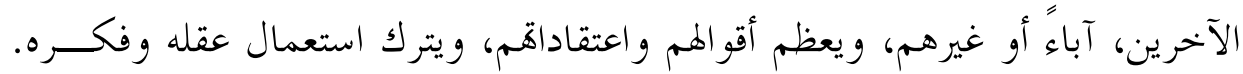

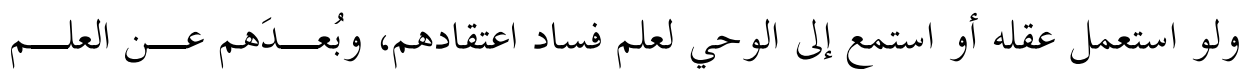

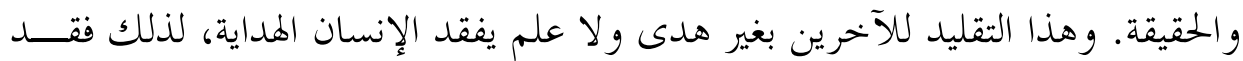

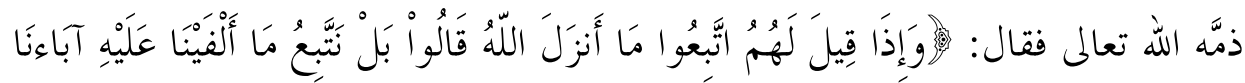

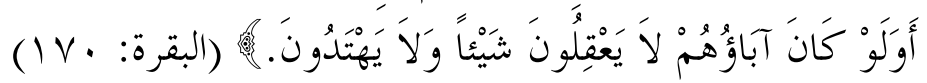

- ومنه الحذر من إلقاءات الشيطان ووساوسه وتشكيكاته؛ فالشـــيطان عــــو،

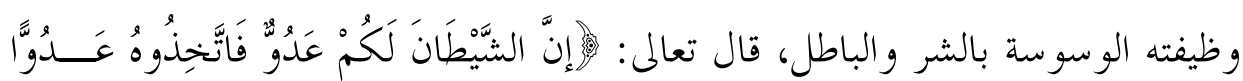

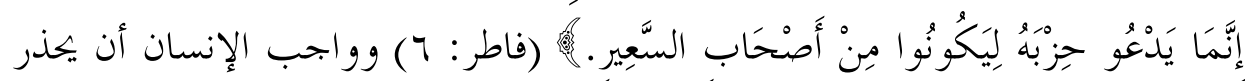

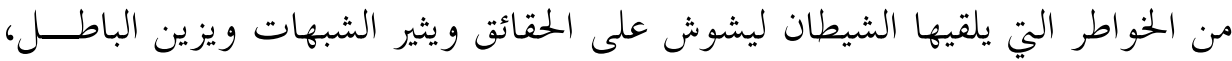

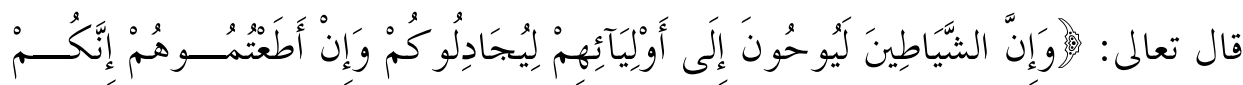

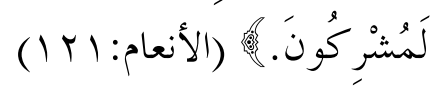

والشيطان يستدرج الإنسان بأوهام لا حق فيها، فالعاقل يحاكم كل وساوسه، ولا

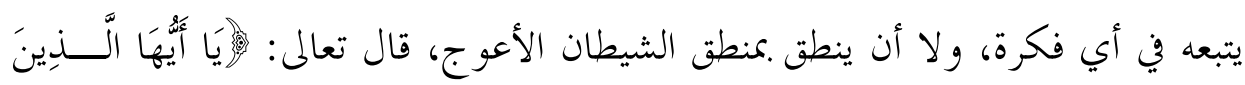

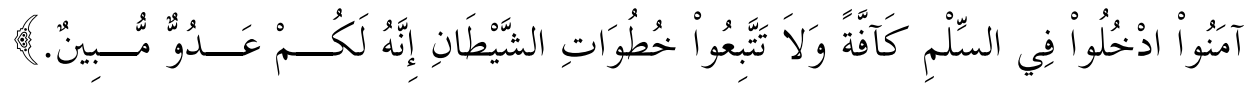

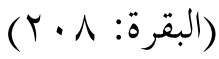

- ومنه عدم الغفلة عن استعمال العقل؛ فكثير من الناس يعيش عمره، و لم يفكـــ

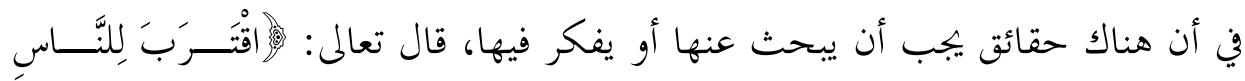

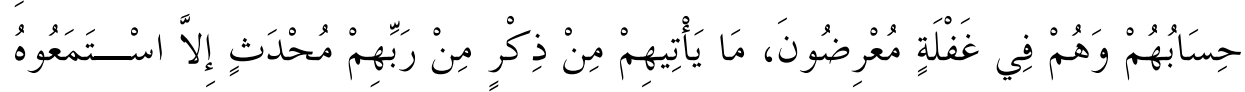

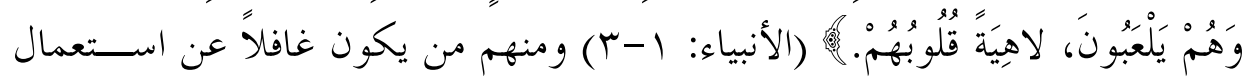

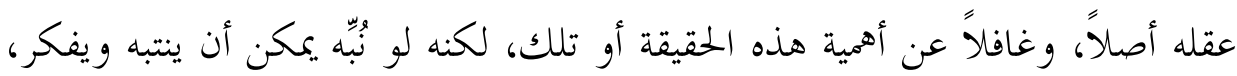
فيهتدي إلى الحق، فهذا غافل العقل. ومنهم من يكون غافل القلب عن أهمية الحقائق، 
رغم أنه يدركها بعقله، فذلك لو سمعها لم يلتفت إليهــا، و لم يتجـــاوب معهــا، و لم

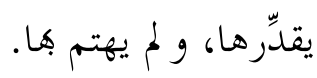

وغالباً ما تنشأ الغفلة بنوعيها عن مسايرة البيئة التي نشأ فيها و متابعتها وتقليــــــا

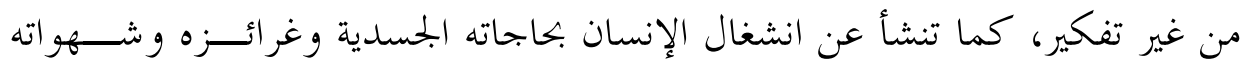

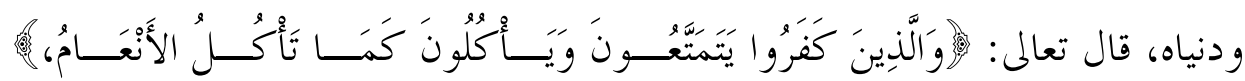

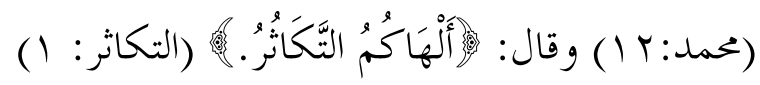

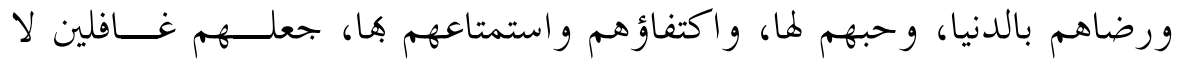

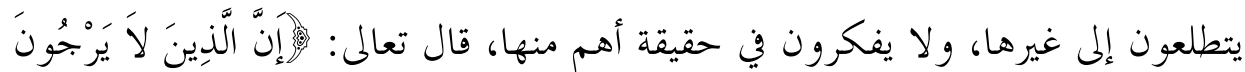

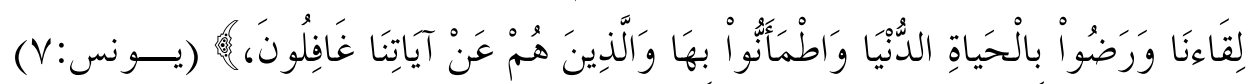
يعيشون في غفلة عن حقيقة أمرهم، فلا يعرفون من هم، و لا ما وظيفتهم المطلوبة منهم

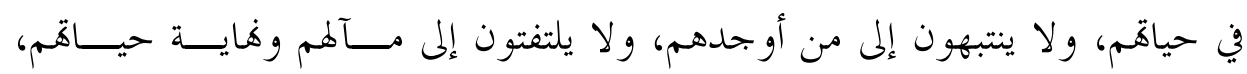

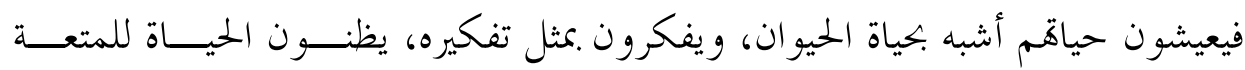

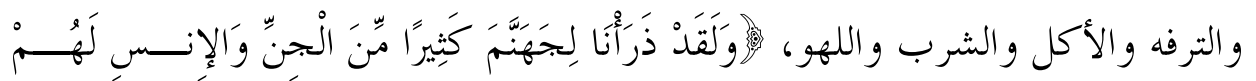

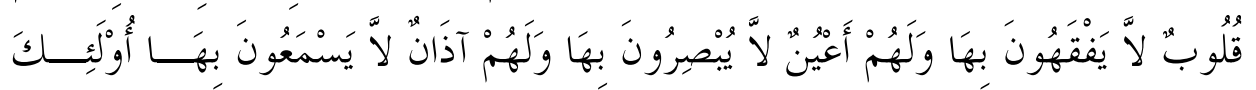

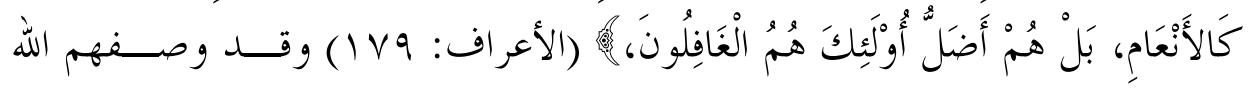
تعالى بالغفلة ليبين أن سبب حالهم من عدم الفقه والإبصار و السمع هو غفلتهم، فــال يخرج الإنسان من حالته التي هي دون الحيو ان إلا أن يترك غفلته ويستيقظ، فكان أول الطريق السليم لسعادة الإنسان أن يطهر نفسه من غفلته باليقظة والانتباه إلى شأنه وما هو مطلوب منه.

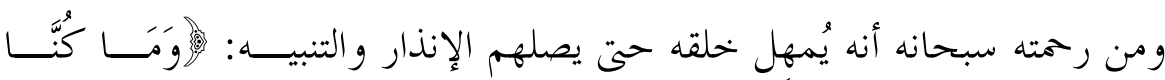

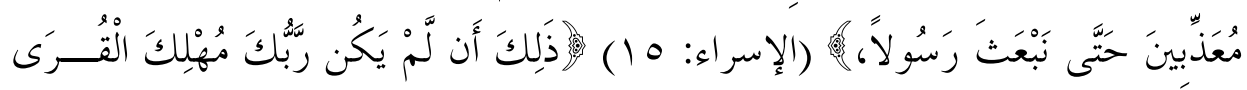

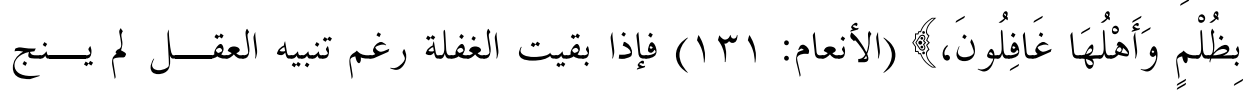




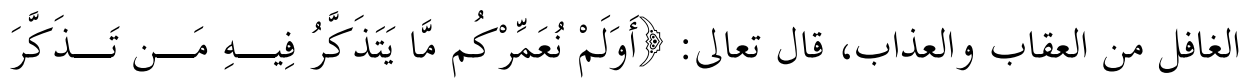

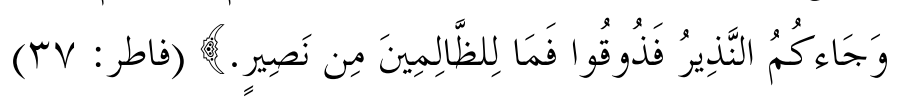

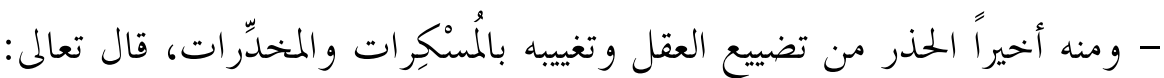

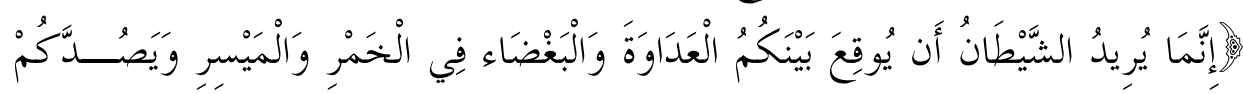

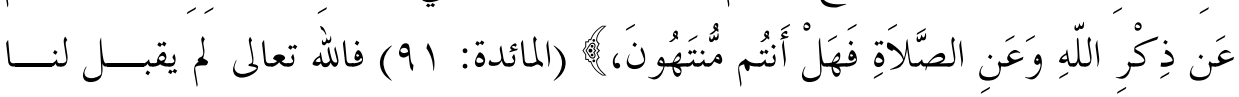

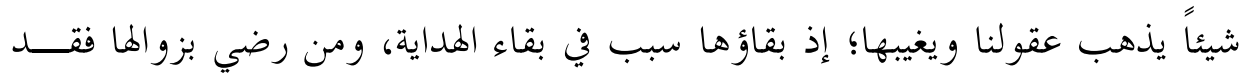
رضي بالباطل والانحر اف عن الحق. ئن.

نستخلص من ذلك أن استعمال العقل بالنظر والتفكير على وفق المنهج الصـحيح

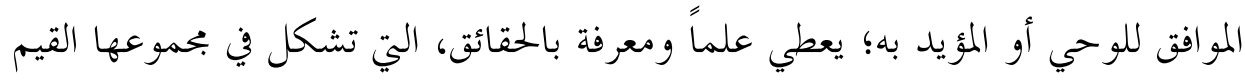

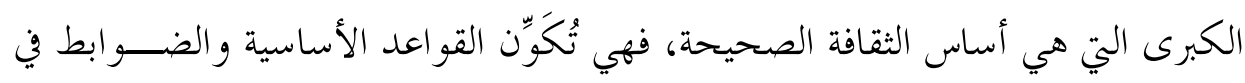
حياة الإنسان على كل مستوى"، سواء على مستوى باطن الإنسان أو ظاهره، قوله أو أو الو

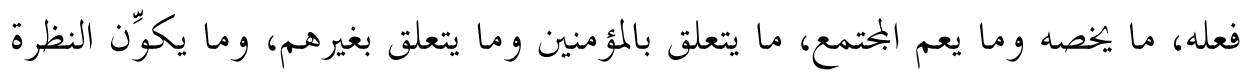

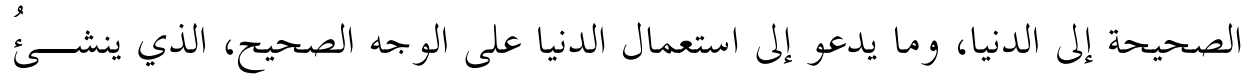

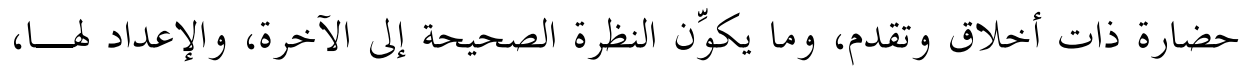
و التأهل لنعيمها الدائم.

\section{ثالثاً: النظر العقلي في موضوعات التز كية وجو انبها}

إن لكل جانب من جوانب تز كية النفس أساساً من النظر العقلي يرجع إليه، ويُبني

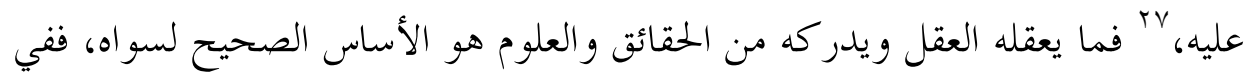

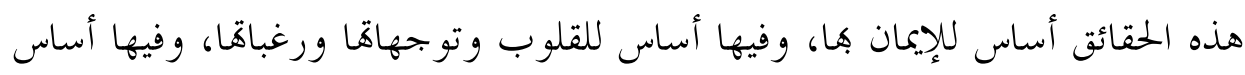

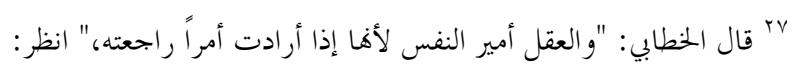

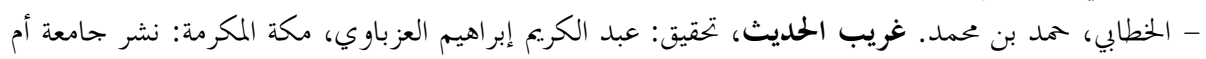

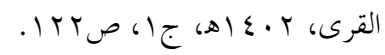


للرجوع إلى حكم الله، وفيها أساس للعبادات، وفيها أساس للأخلاق، وفيها أســاس

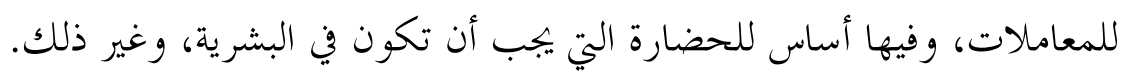

\section{1 ـ ربط القر آن بين العقيدة وأحكامه التي بها تز كية النفوس:}

لقد ربط الله تعالى في آيات كثيرة بين الإميان، والأعمال، والأخلاق، والاستقامة

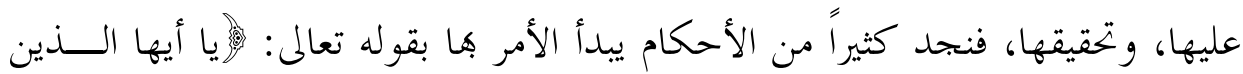

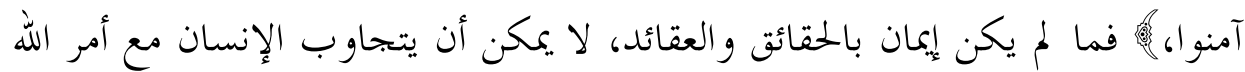
وحكمه. ومن نماذج ربط الأحكام بالإيمان:

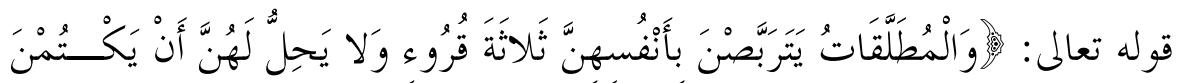

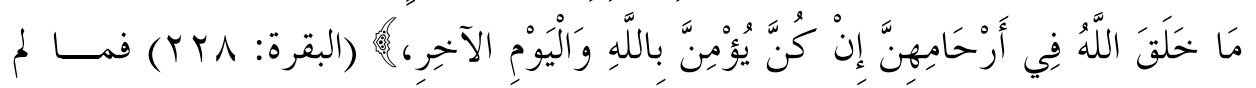

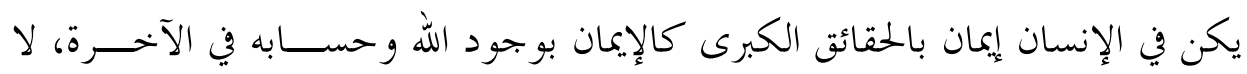

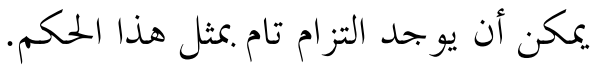

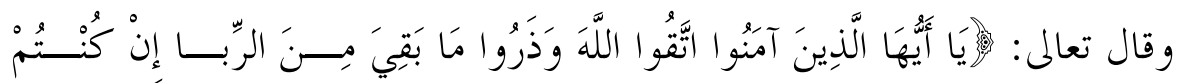

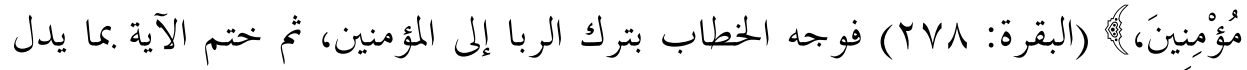

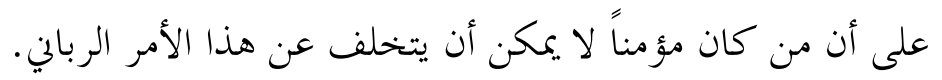

\section{Y. معرفة الحقائق أساس للإيمان بها، ولا تز كية إلا مع الإيمان:}

فالحقائق المعقولة هي التي يجب أن نؤمن هـا ونصدق ها؛ لأها حق ثابت، ومــــالم

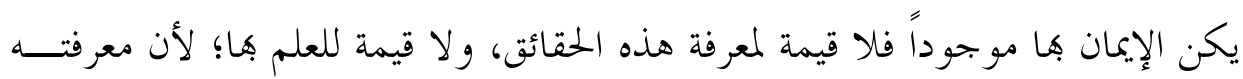

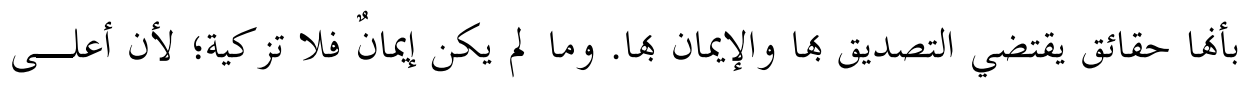

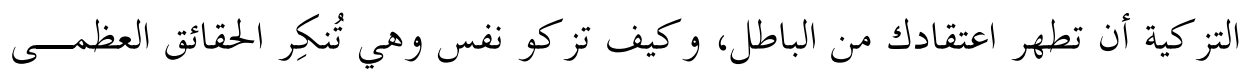

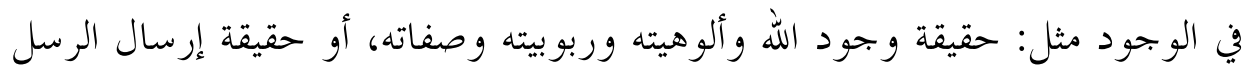
وإنزال الكتب، أو حقيقة اليوم الآخر. 


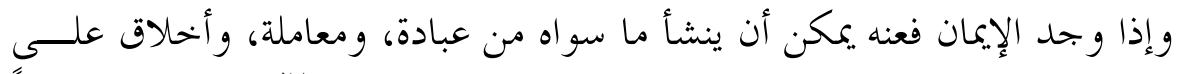

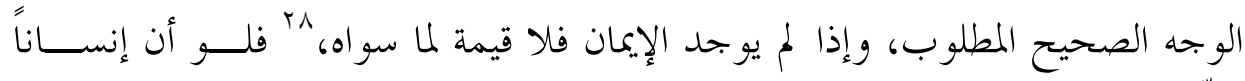

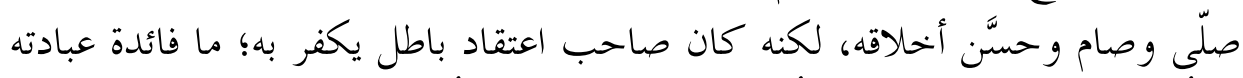

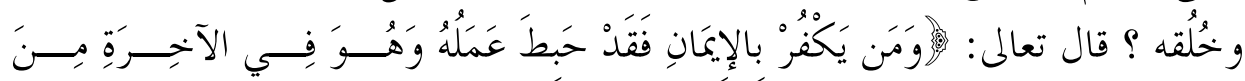

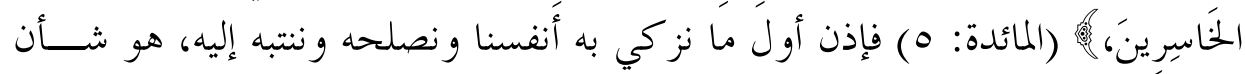

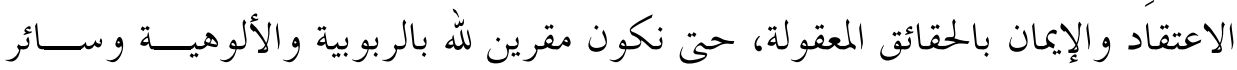

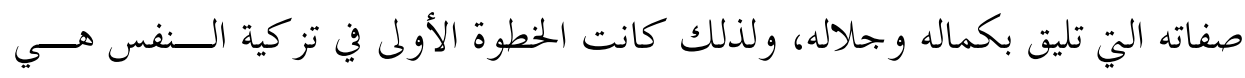

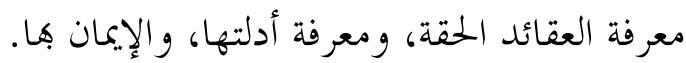

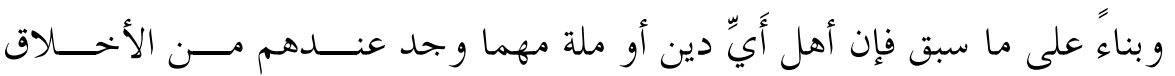

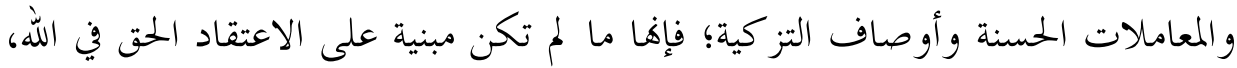

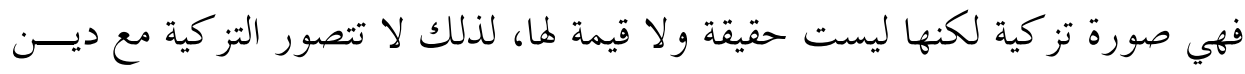

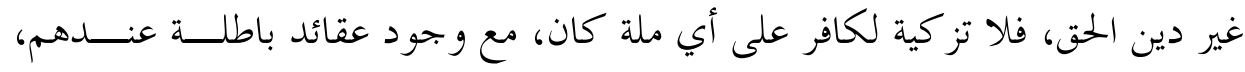
ومع عدم خضوعهم وإذعاهم لإسلام الحق.

\section{r. بيان منطقية التزكية في جو انبها المختلفة، وابنتائها على الإيمان بالحقائق:}

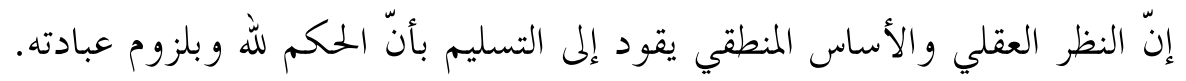

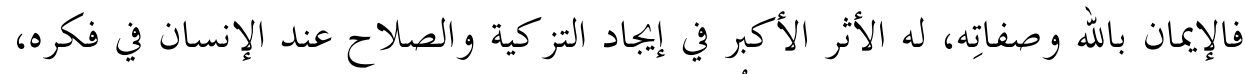

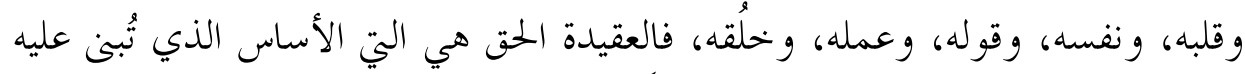

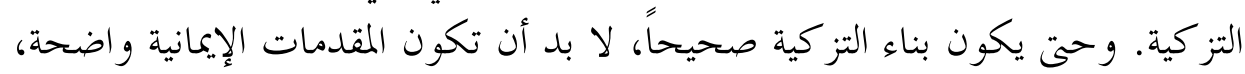

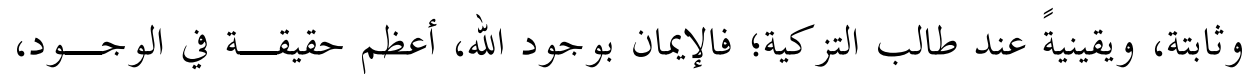

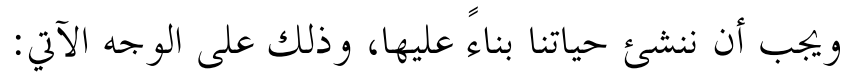
- لما كان الله هو الخالق لكل شيء، فالو جود كلُّه له و كلُّه ملكه.

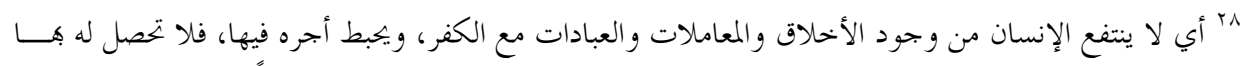

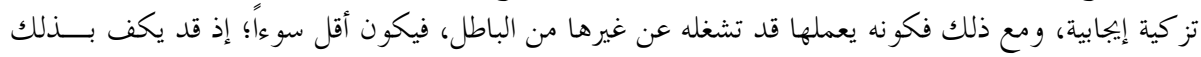

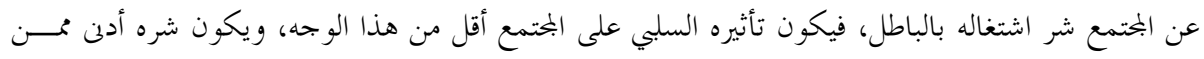

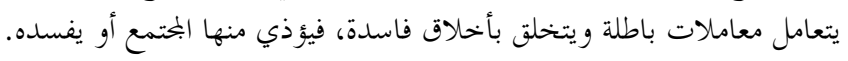




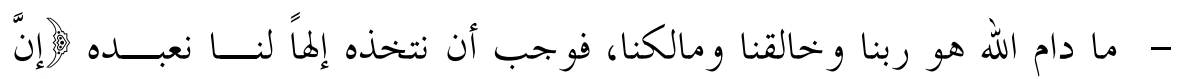

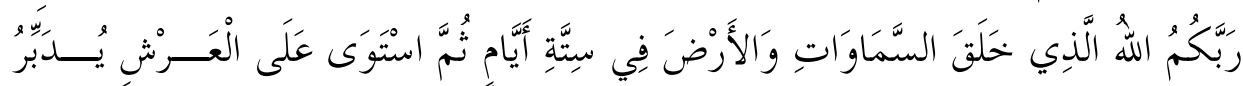

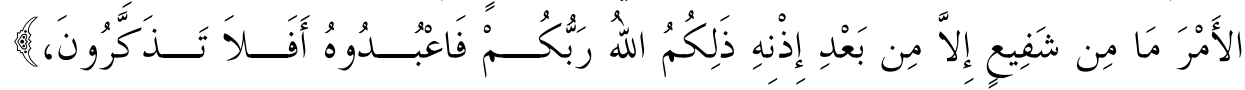

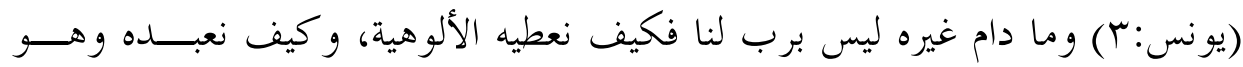

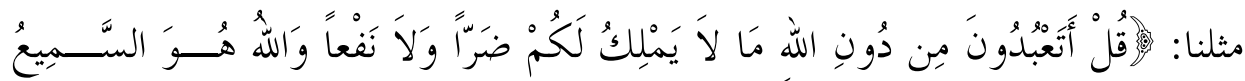

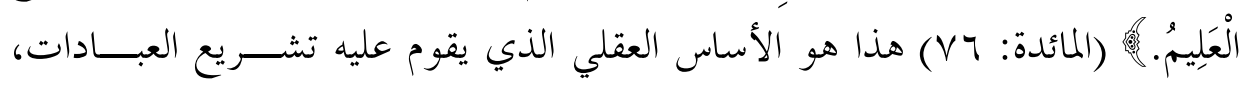

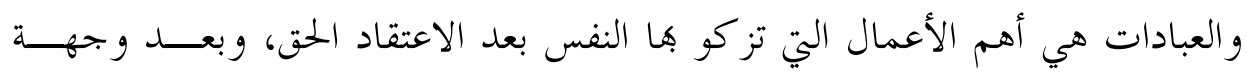
القلب السليمة.

- مالك الشيء أحق بأن يَحْكُم في ملكه، فالله أحق بالحكم في كل مخلوقاتسه.

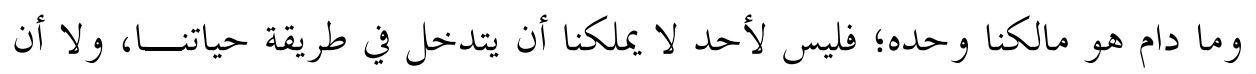

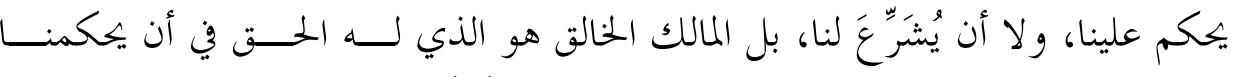

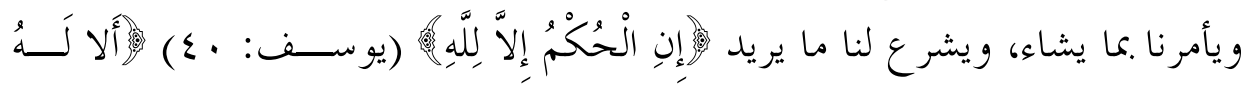

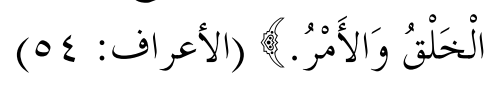

- - ما دام الله هو الحاكم الآمر، الذي يستحق وحده أن يحكم، فلا بدَّ من طاعته

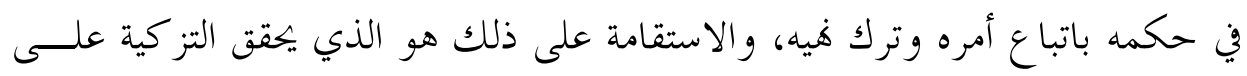
كمالها.

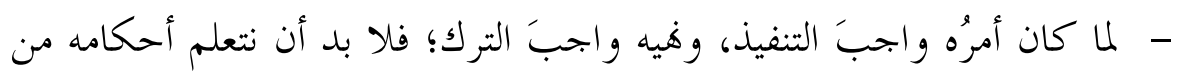

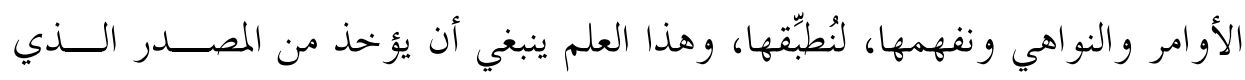

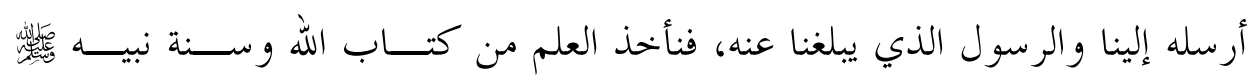

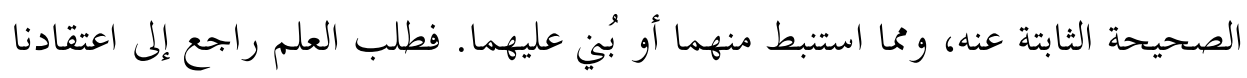

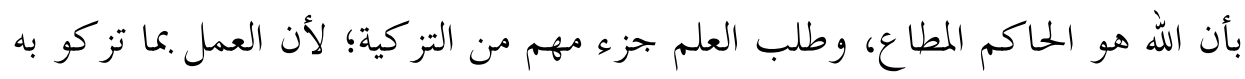
النفوس لا يكون إلا بعد العلم به. 


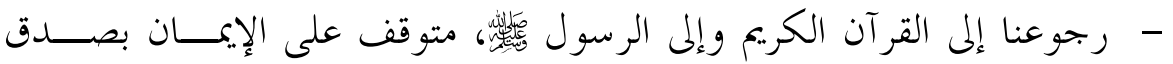

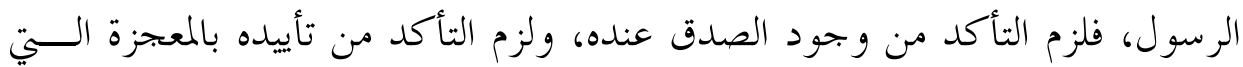

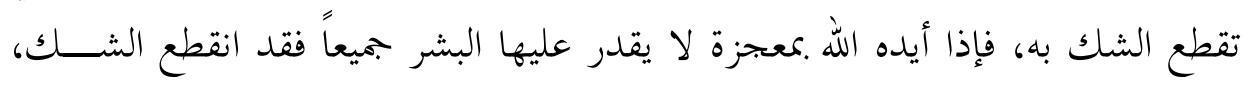

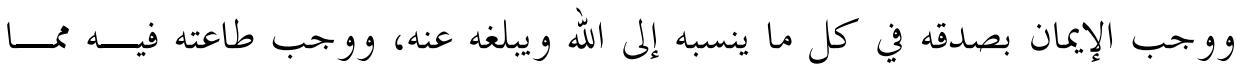

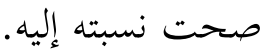

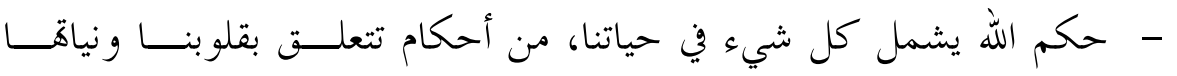

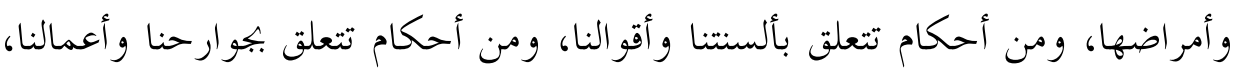

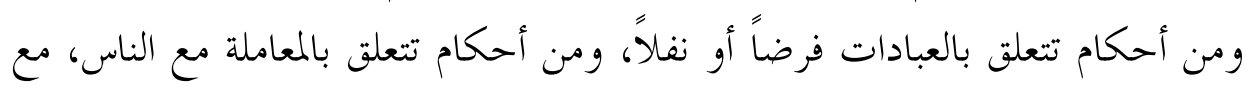

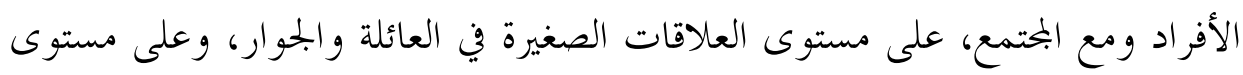

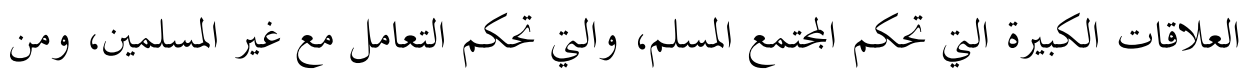

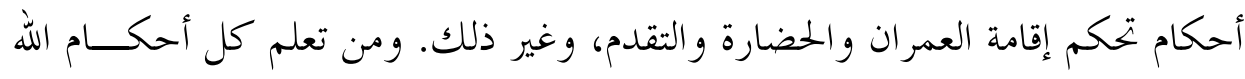

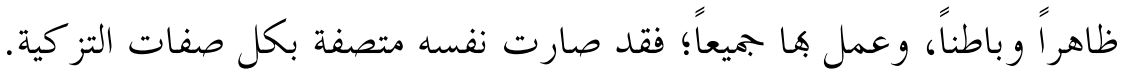

ولا شك أن في كل أمر وفي مصالح ومنافع يدركها العقل، ولكن سواء أدركها

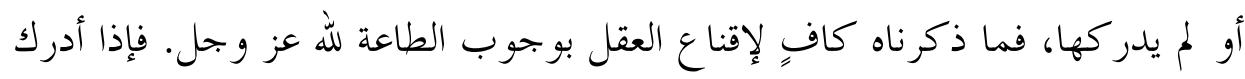

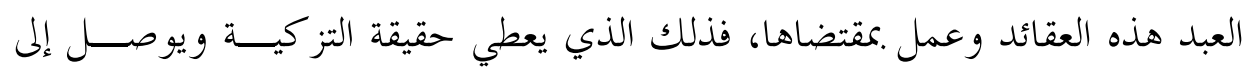

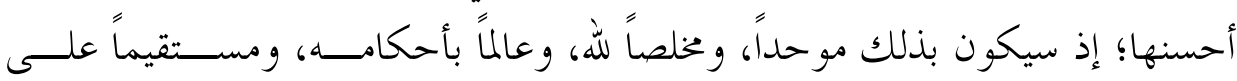
أحكامه في كل حال. أحسن.

\section{ع ـ النظر العقلي أساس لتحديد أهداف التزكية:}

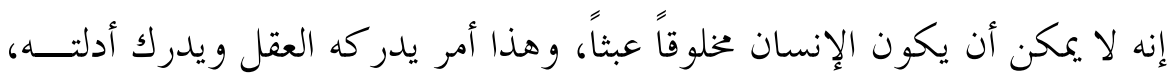

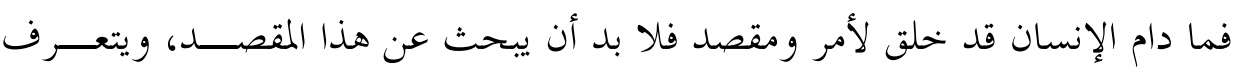

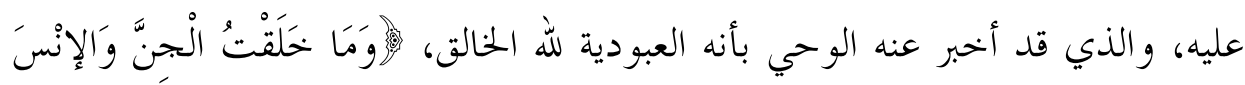

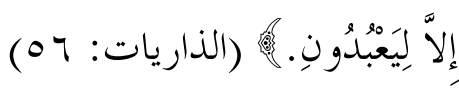


ووجود هدف عند الإنسان يسعى إليه، هو الذي يشكل الدافع الأقوى للأعمال التي توصل إلى ذلك الهدف، وبقدر حضور الهدف عند من يزكي نفسه، تتولد همة إلى الأعمال الصالحة، وعفة عن الأعمال السيئة.

وأهداف التزكية كلها تدور حول معنى العبودية، لكنها بالالتفات مـــن زوايــــا

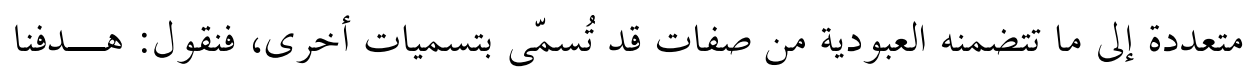

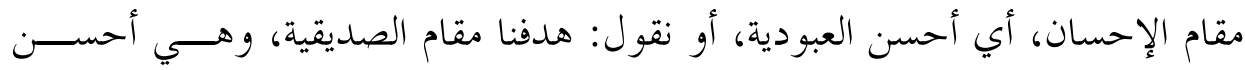
العبودية وأعلاها، أو نقول: هدفنا رضا الله، وإنما يكون رضاه بالعبودية له، أو نقول:

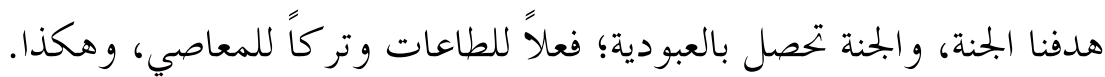

\section{هـ أثر التعقل في الوصول إلى مقامات التز كية العليا:}

إن العقائد المعقولة بالعقل فضلاً عن أها تُنشئ أساس التز كية، فإن حضــــورَها في

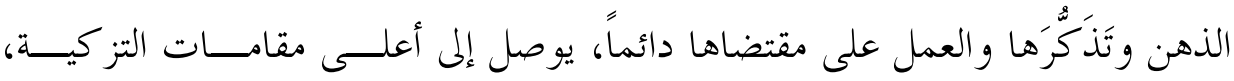
وتمر اها العظيمة، و ومنها:

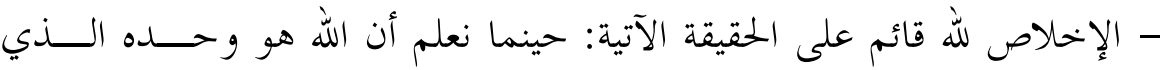

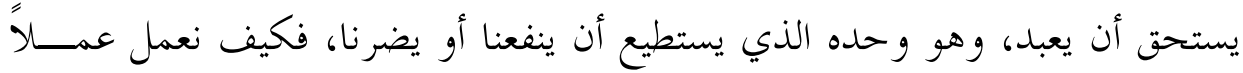

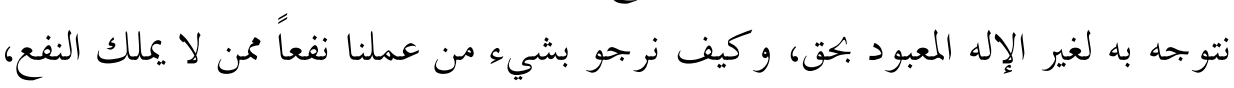

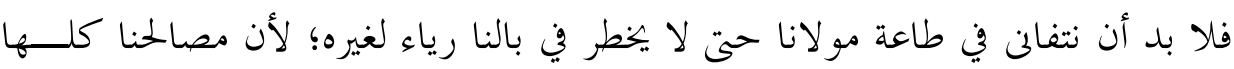
راجعة إلى الله.

- حب الله قائم على الحقيقة الآتية: الله تعالى هو المتصــف بصــفات الكمــــال

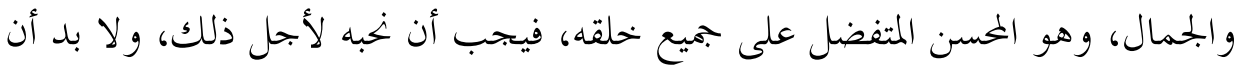
نبين على حبه كل حب و كل علاقة؛ لأن مصالحنا ترجع إليه ومتوقفة علــى فضــلهـ،

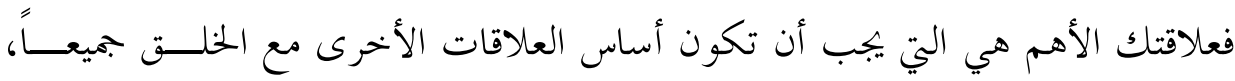
فنحب من أحب الله ونو اليه ونصاحبه، و نبغض من أبغض اللهّ و نتبرأ منه و نفارقه. و وهذا الها يقتصي ذكره و الحضور معه وترك معصيته. 


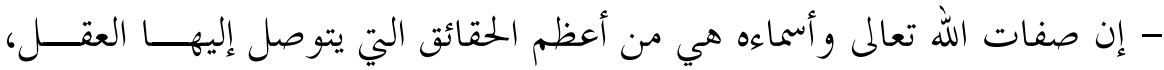

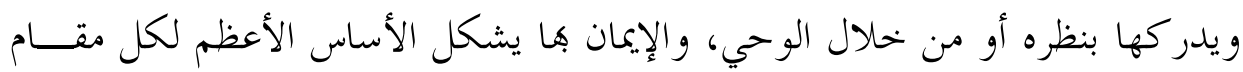

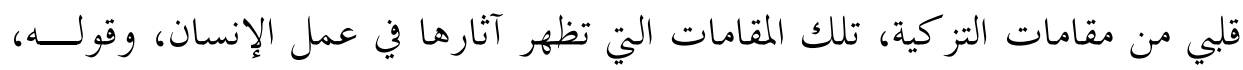

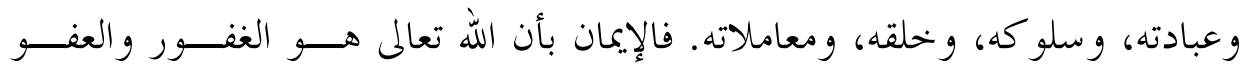

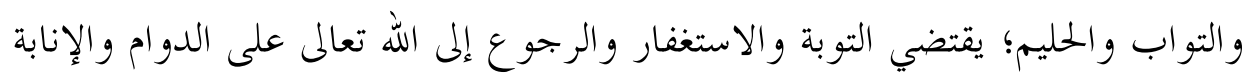

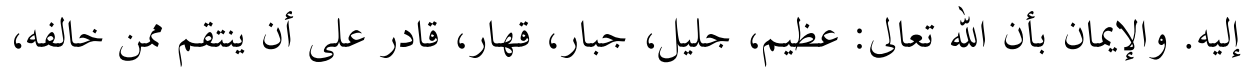

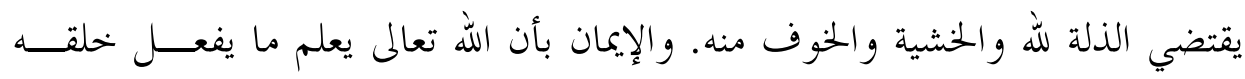

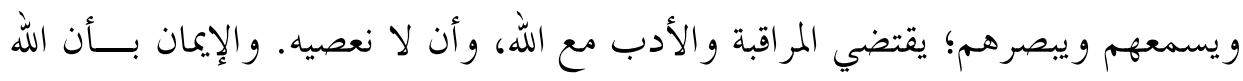

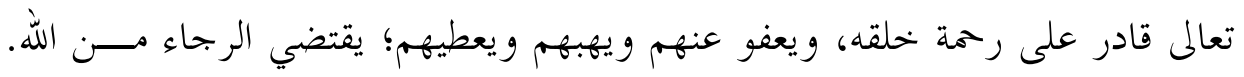

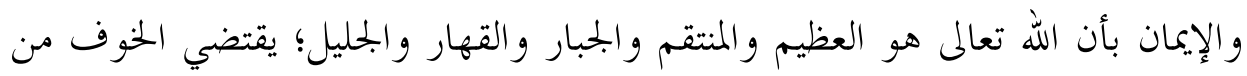

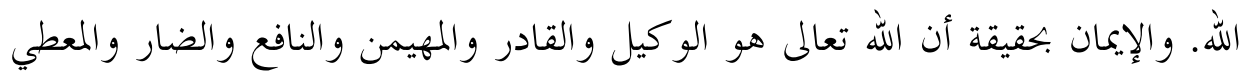

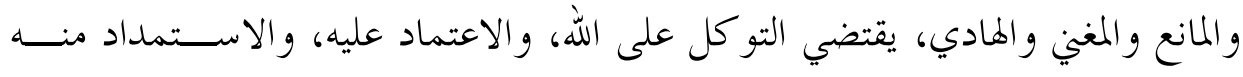

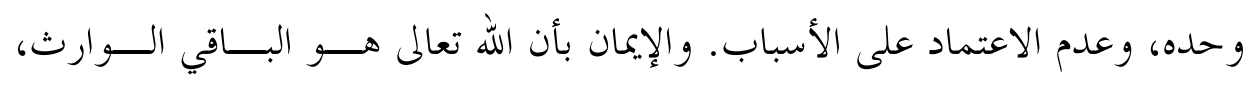

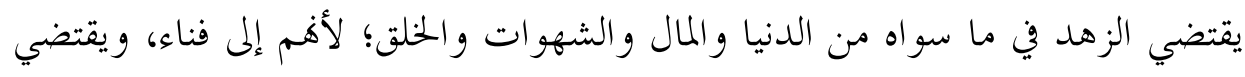

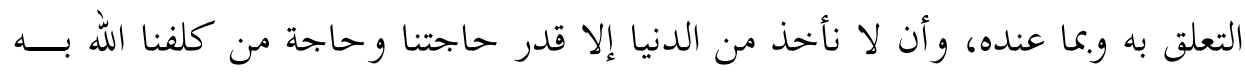

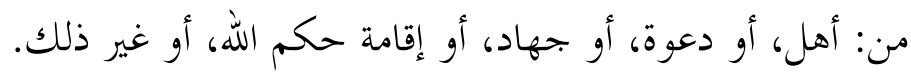

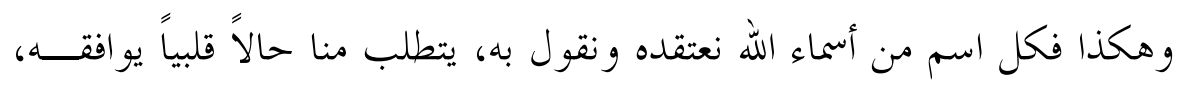

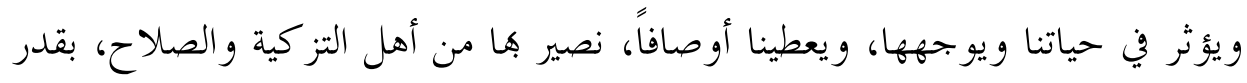

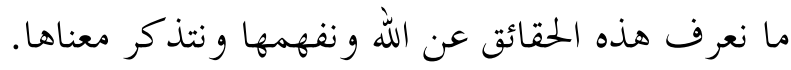

\section{4. النظر العقلي الموجب لبحاهدة انحراف القلب وأمراضه:}

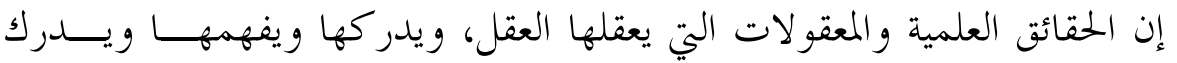

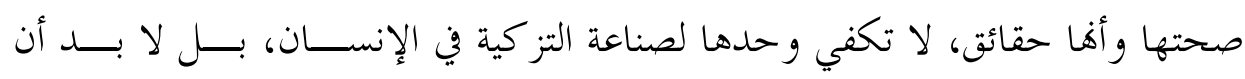

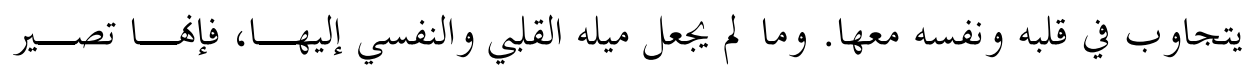
كالمعدومة البجهولة عند من يميل بقلبه إلى خلافها. 
فإذا كان قلب الإنسان لا يريد الخير والحق، وإنما يريد شهواته وغرائزه و مصالحه

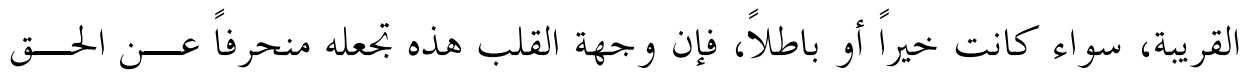

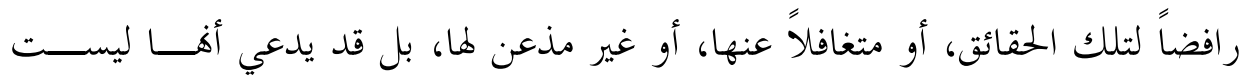
بالحقائق وأها باطل رغم ظهورها، كل ذلك ينشأ عن انخر اف القلب وميلــهـ الباطــلـ

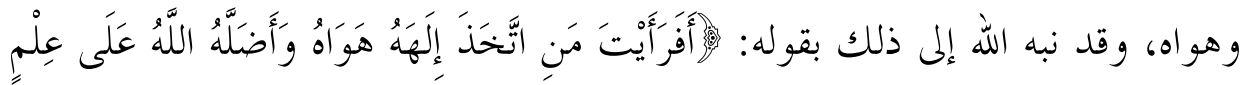

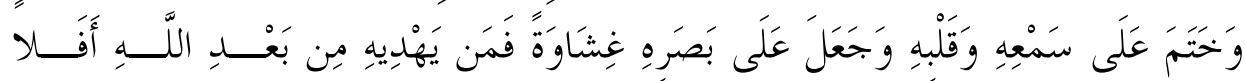

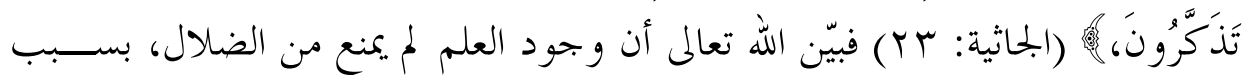
وجود الهوى، الذي يسيطر على الإنسان حتى يصير إلهاً مطاعاً من دون الله.

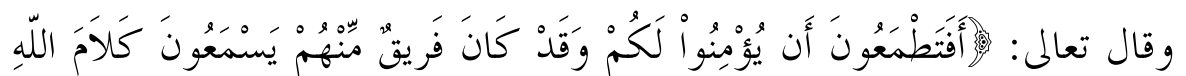

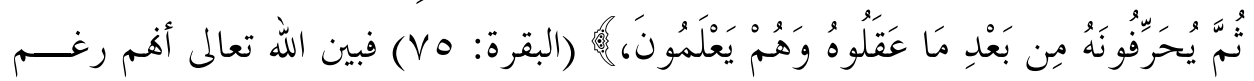
تعقلهم للحق لم يتبعوه، بل حرفوه و كذبوا .بما أدركو اصو ابه وأحقيته.

وقد أخبرنا الله سبحانه هـا عن كثير ممن الخرفو اعن الحق إلى الباطل رغم علمهـــم

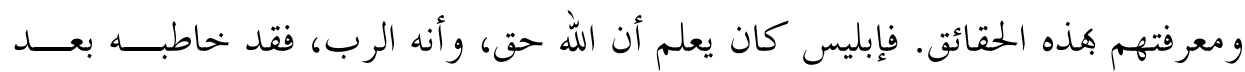

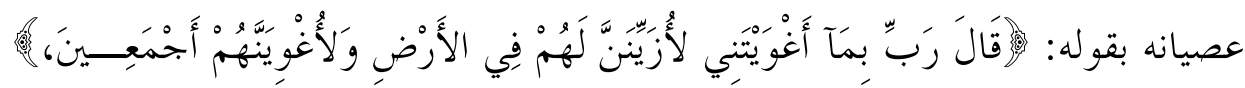

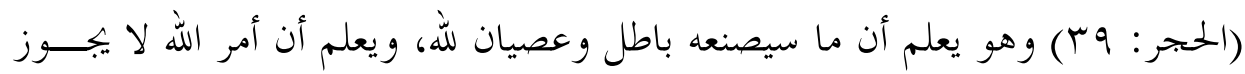
أن يخالف، لكن وجود انحراف في القلب مرض جعله يغطي كل هذه الحقائق، ويسير طريق المخالفة لله، فما الذي جعله يفسق ويخرج عن أمر الله ؟ إنه مرض الكِبْر، قـــال

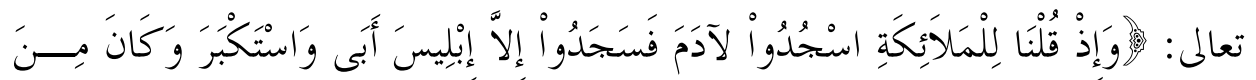

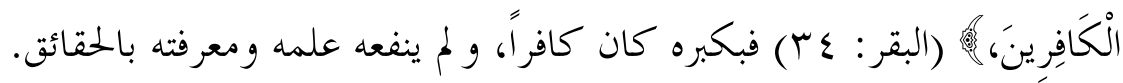

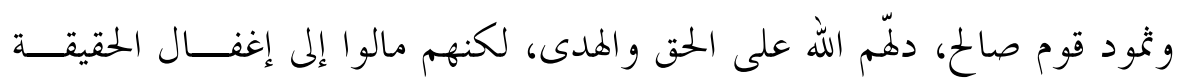

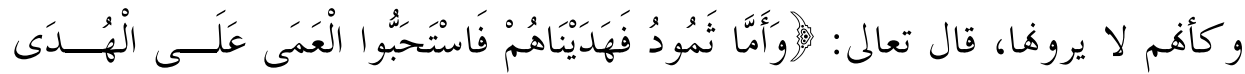

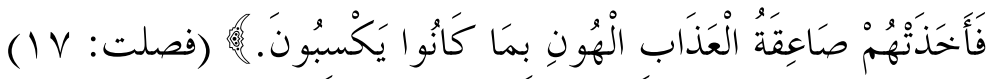




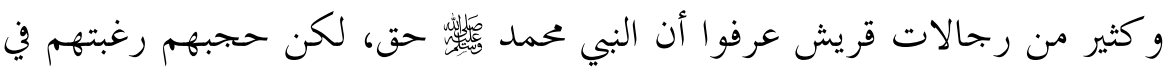

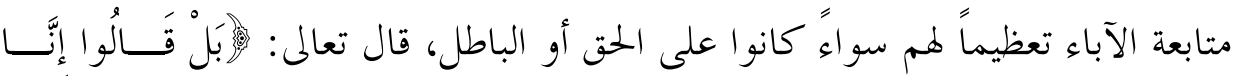

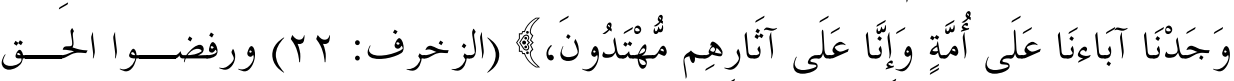

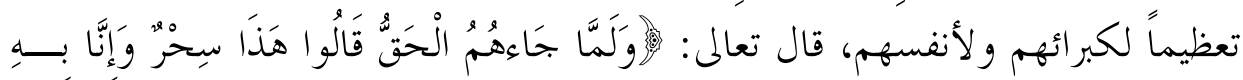

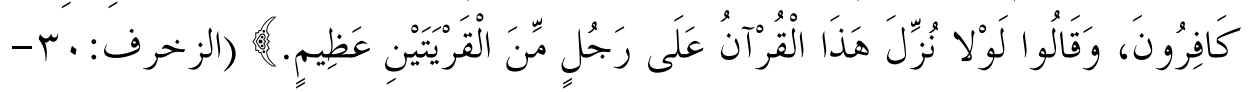

واليهود كانو ا يعلمون أنّ الله سبحانه سيرسل نبيّاً ويعلمون صفاته، فلما جاء البيي محمد

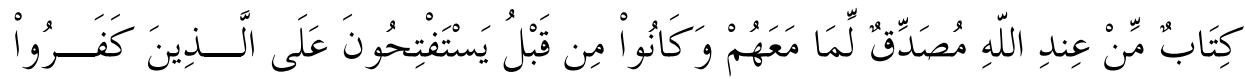

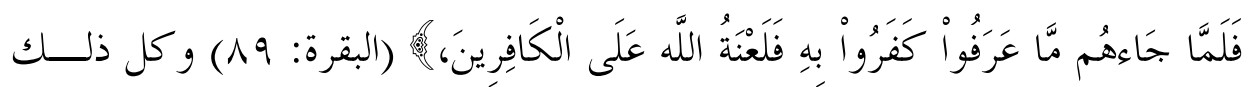

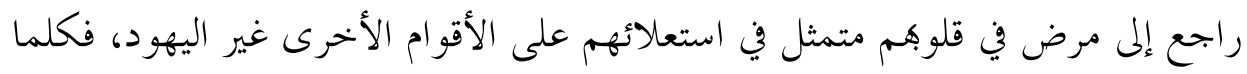

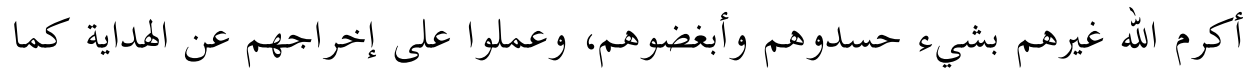

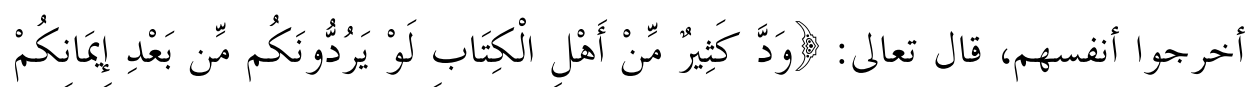

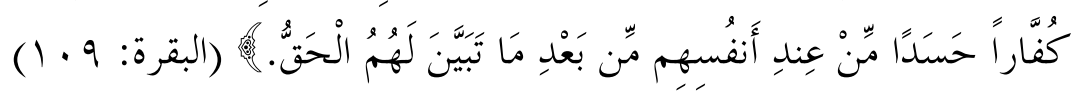

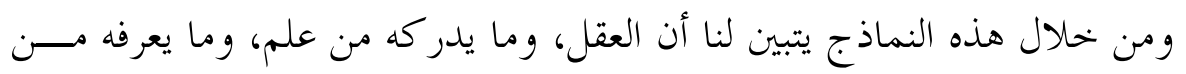

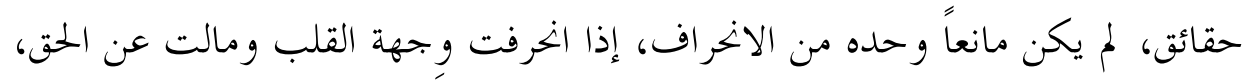

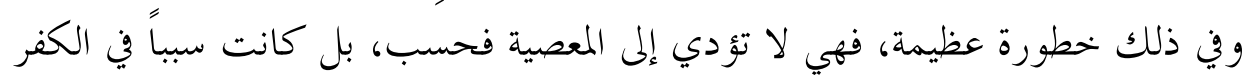
أحياناً.

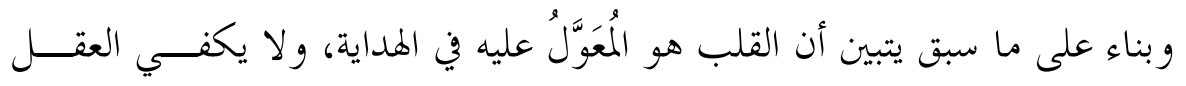

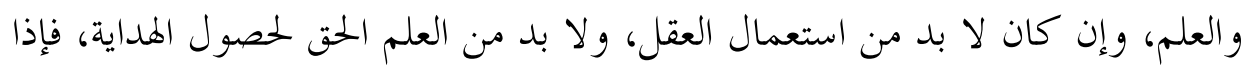

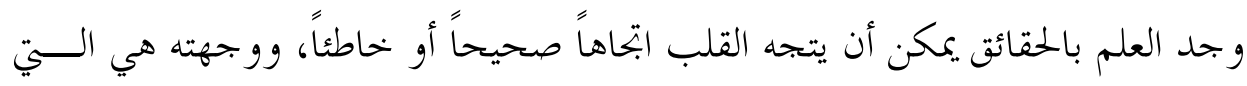




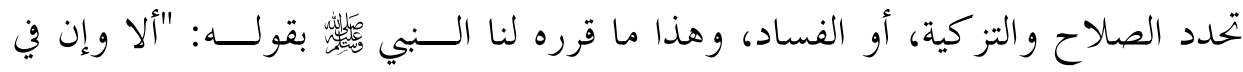

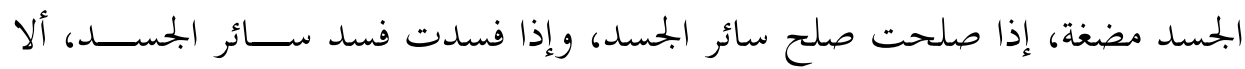

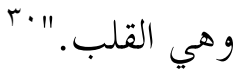

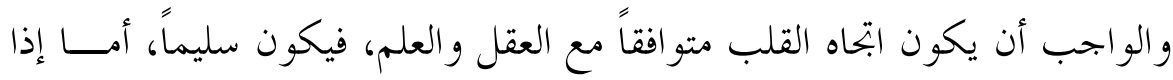

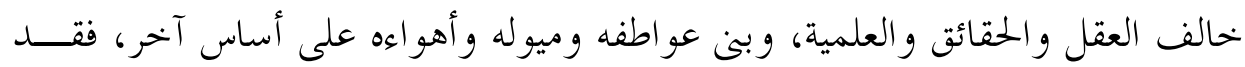

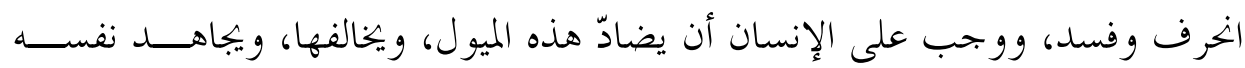

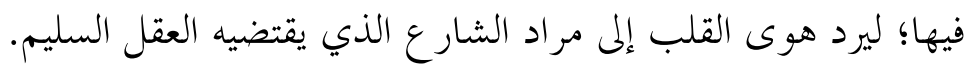

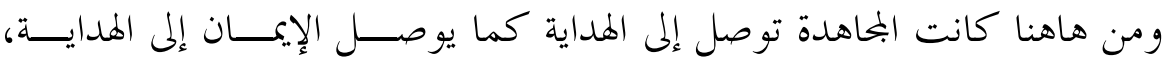

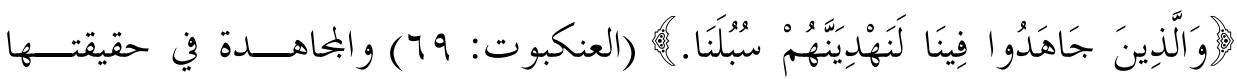
رجوع إلى العقل والحق، ذلك أن الإنسان كلما دعته نفسه وهو إهاه إلى فعل أمر تشتهيه

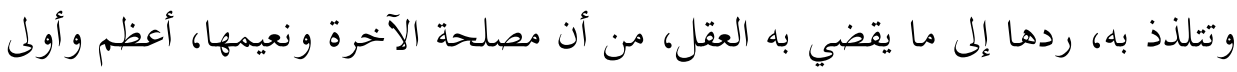

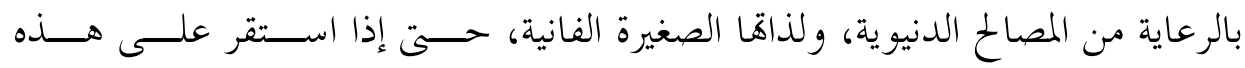

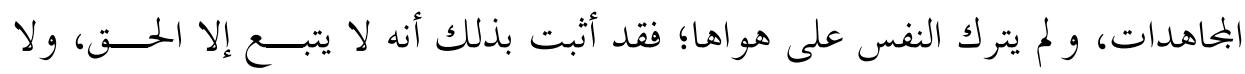

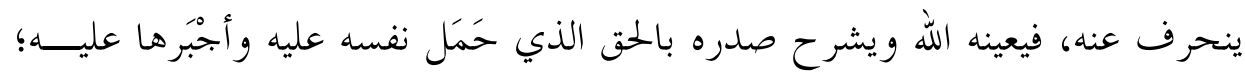

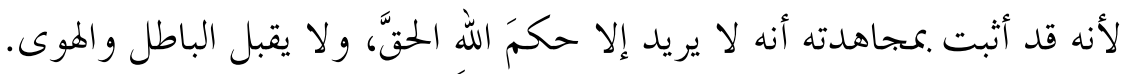

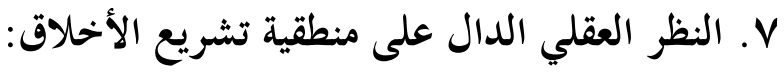

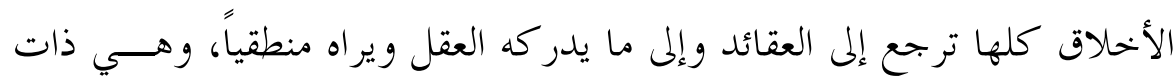

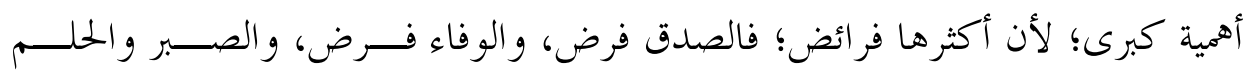

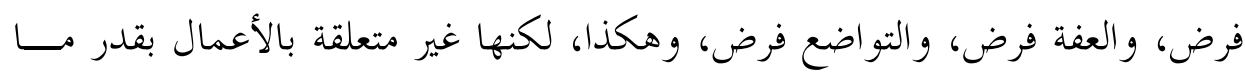

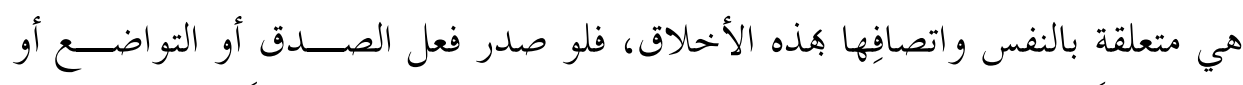

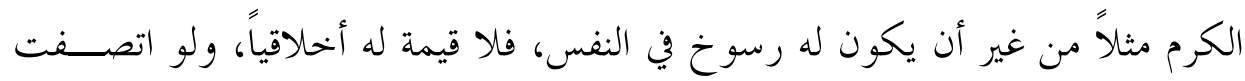


النفس هذذه الأخلاق فهي معتبرة وينتفع منها صاحبها، ولو لم تظهر فعلاً على الجوارح عند عدم وجود ما يقتضي ظهورها.

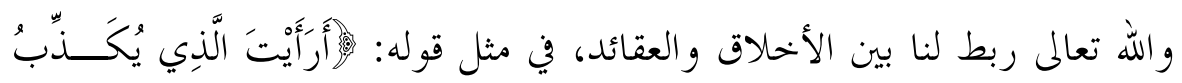

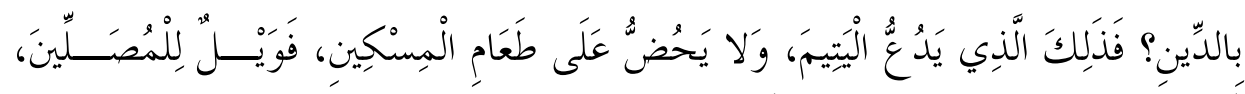

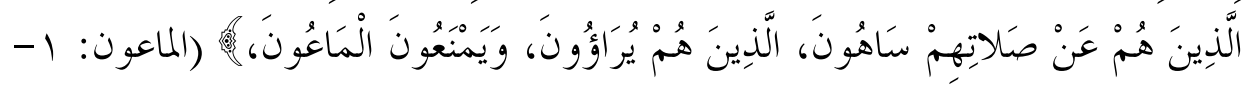

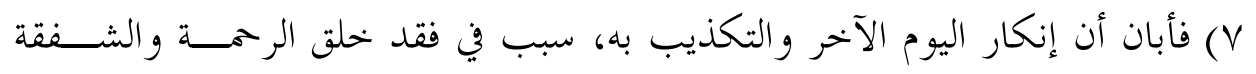

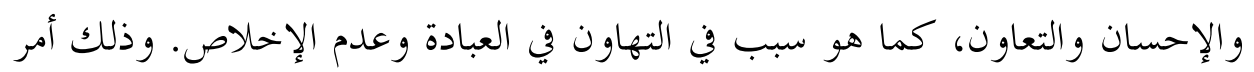

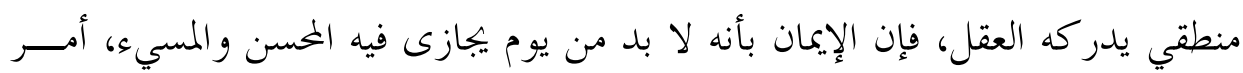

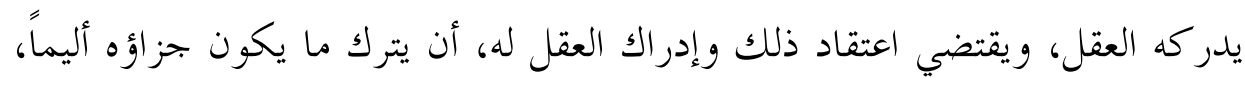
ويحرص على ما يكون جزاؤه حسناً.

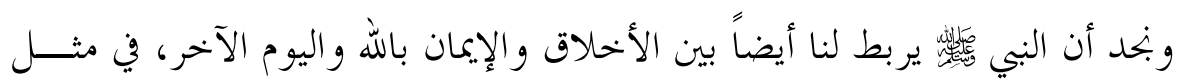

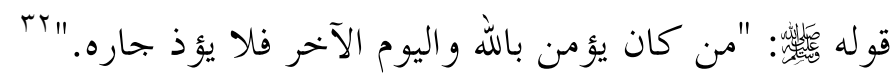

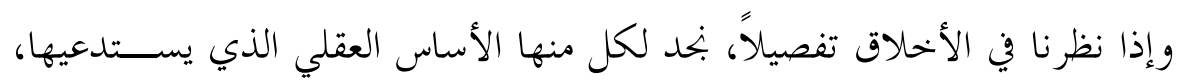

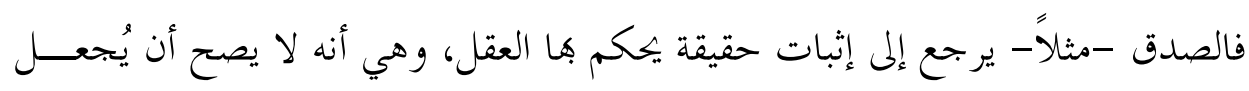

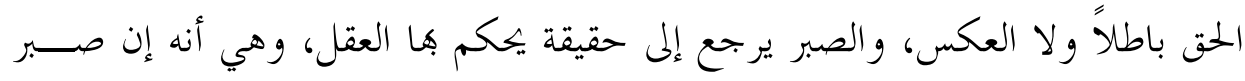

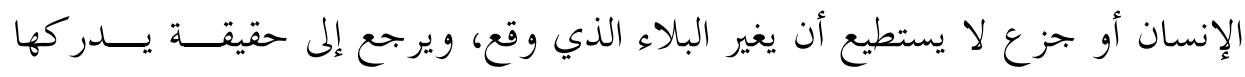

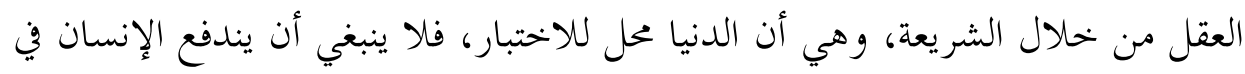

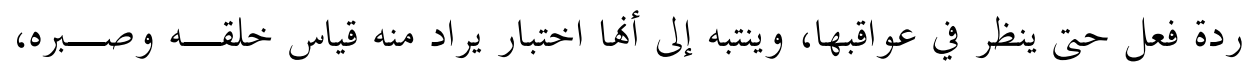

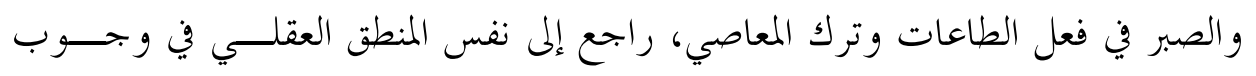
الاتباع فيها.

"ا" أما إذا وجد ما يقتضيها، و كان قادراً على أدن شيء من مظاهرها، فلا بد من ظهور ها. وعدم ظهورها عندئذ

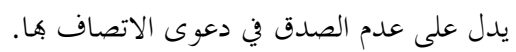

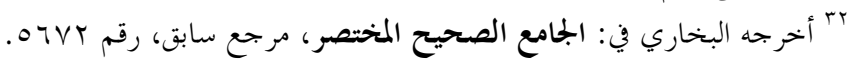


وخلق الكرم والإنفاق مبني على عقيدتك بأن الله هو الرزاق، وأن بذل المال لله لا

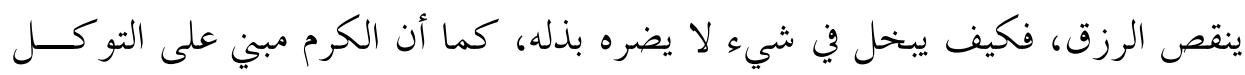

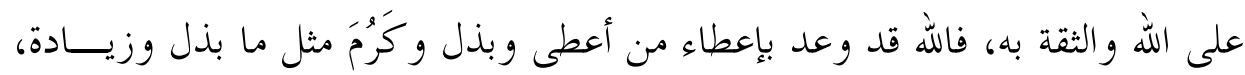

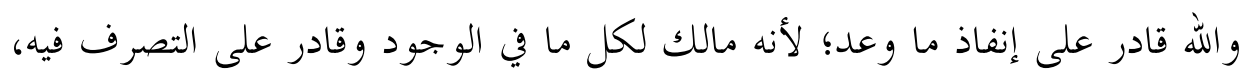

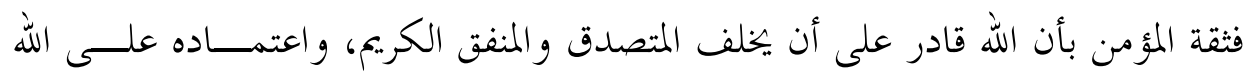

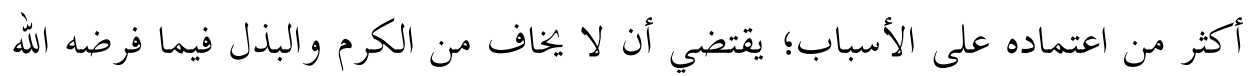

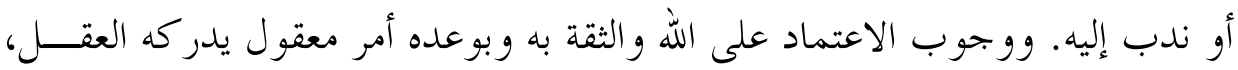

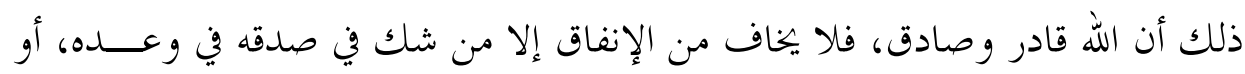
شك في قدرته على إعطاء المنفق.

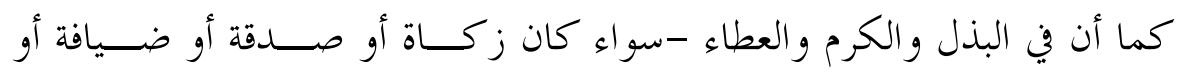

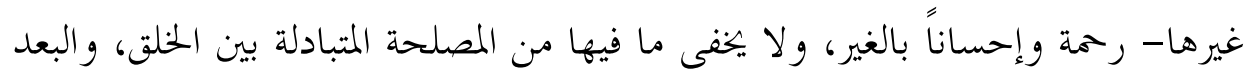

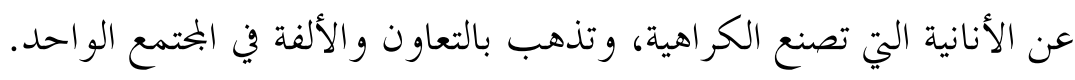

وخلق الشجاعة مبني على الثقة بالله والاعتماد عليه والحضور معه، فكيف يخاف

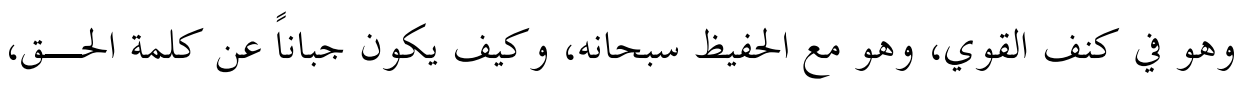

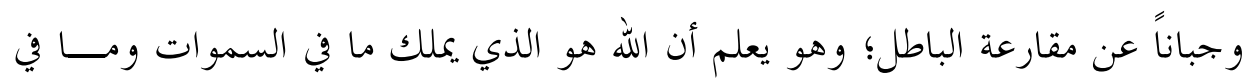

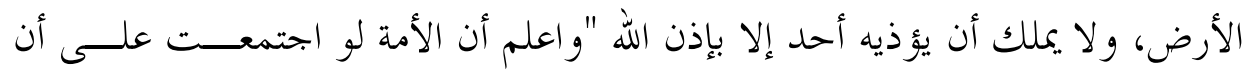

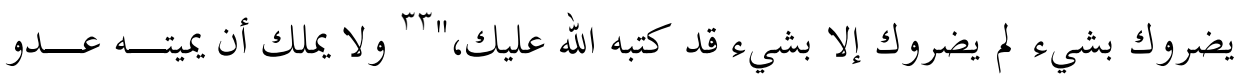

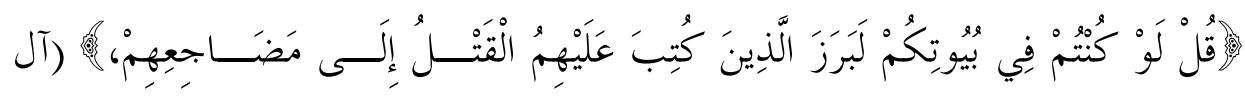

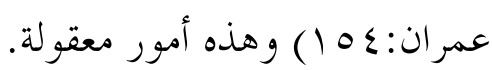

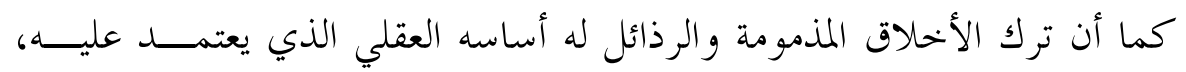

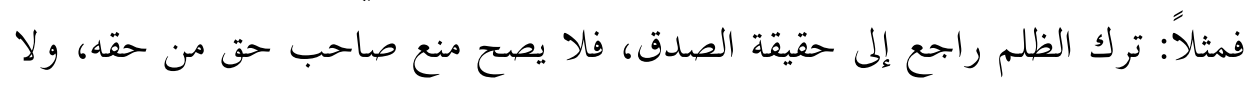




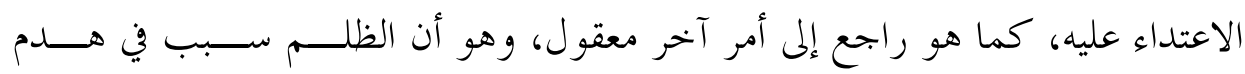

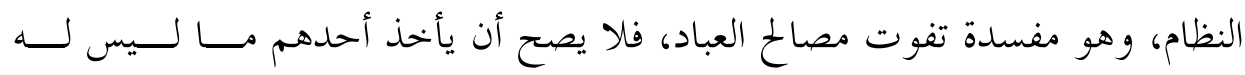

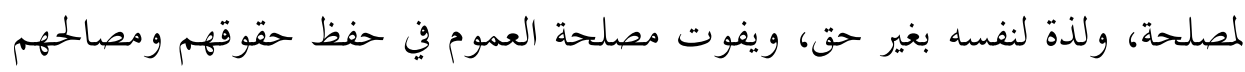
الثابتة لم.

\section{^. النظر العقلي الدال على معقولية تشريعات المعاملات:}

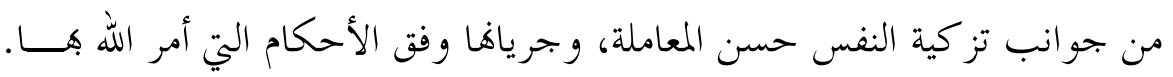

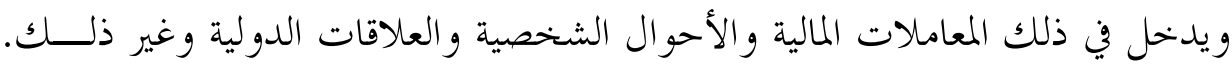

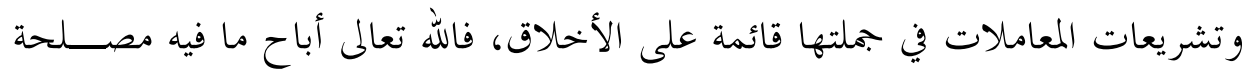

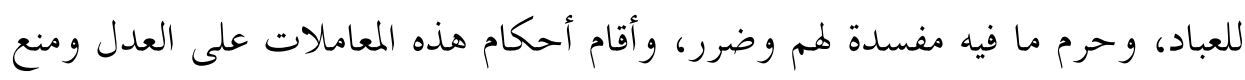

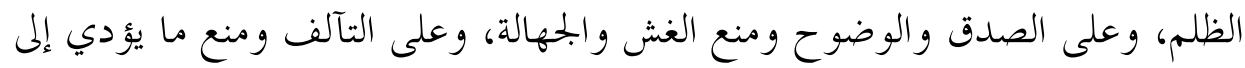
الخصومات والبغضاء. وهذه جميعاً أمور يدرك العقل حسنها والعن ومصلحتها.

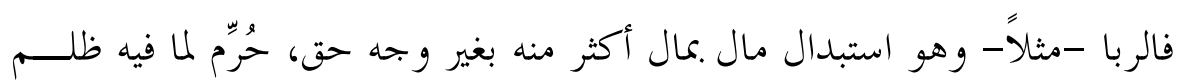

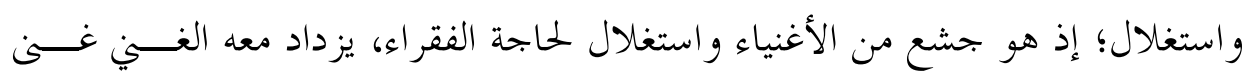

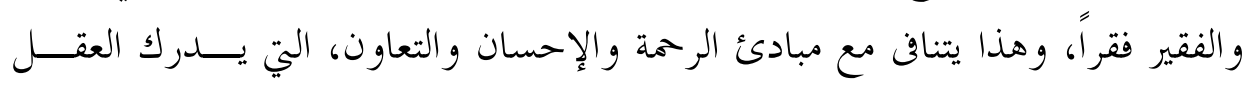
حسنها.

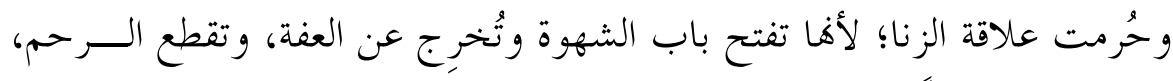

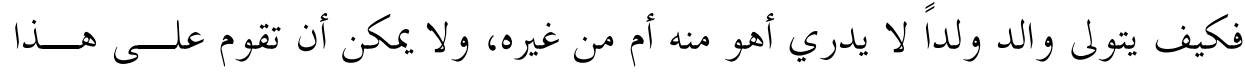

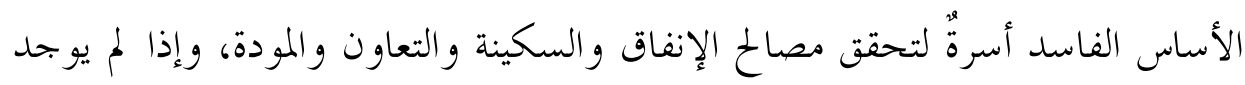

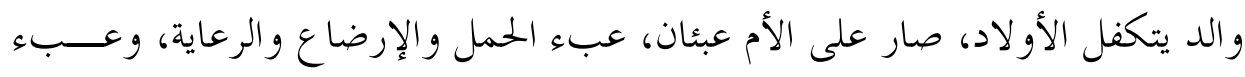

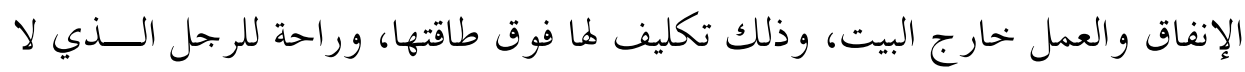

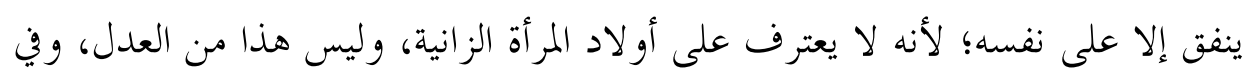

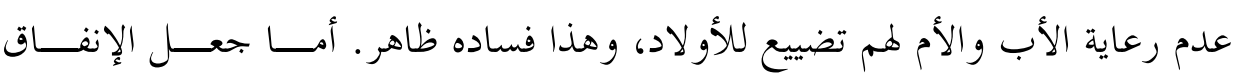

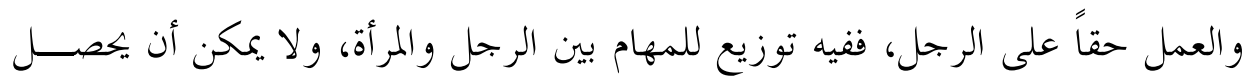


ذلك إلا باشتراكهما الحقيقي في الأبوة، وذلك لا يكون إلا عند الاقتصار على الزواج دون الفاحشة.

بالإضافة إلى أن العمل بأوامر الله هو مصلحة واضحة، يدرك العقل وجوها - كما

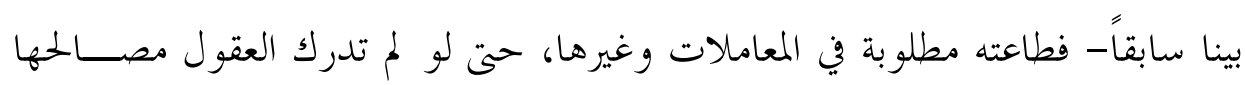
التفصيلية.

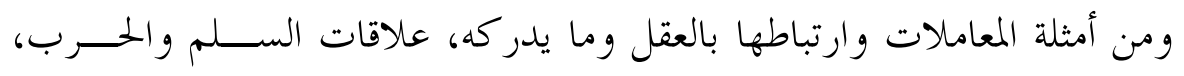

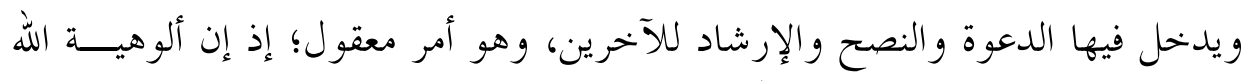

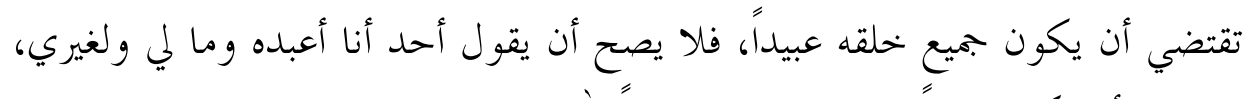

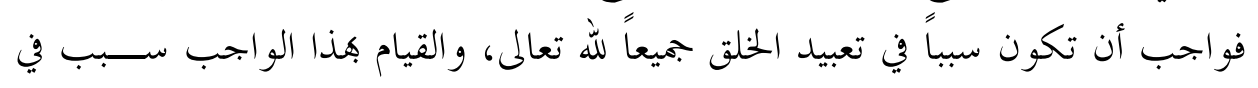

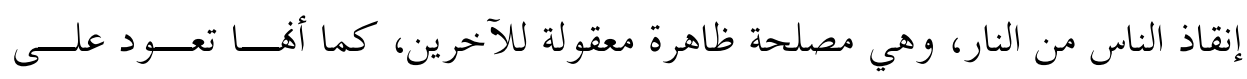

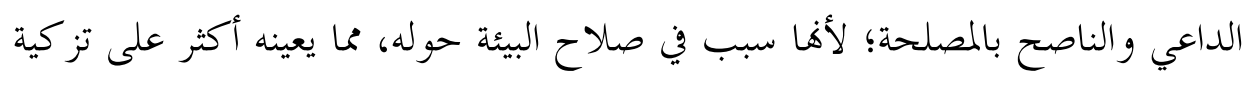

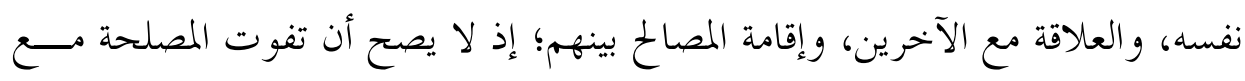

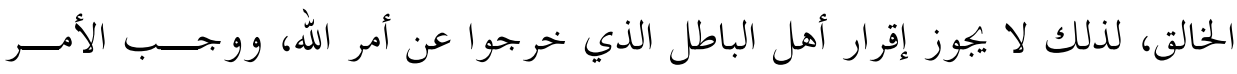

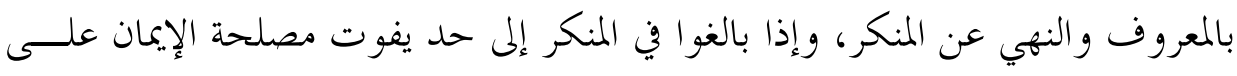
الخلقى، وجب جهادهم.

والجهاد فيه تضحية بالمال وتضحية بالنفس، وهو أمر منطقي معقول؛ إذ لا يصح

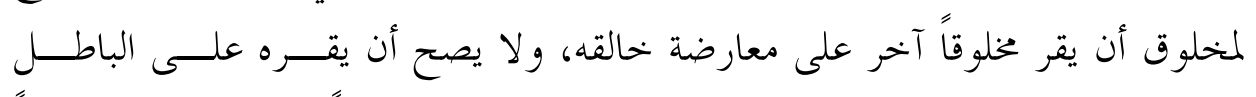

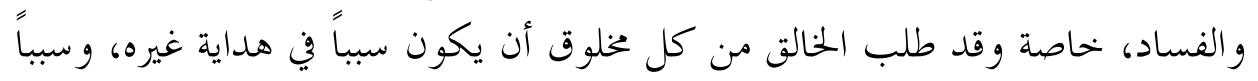

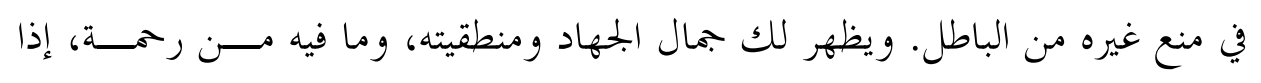

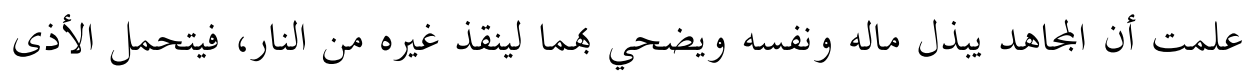
والجرح إحساناً إلى غيره، بأمر ربه.

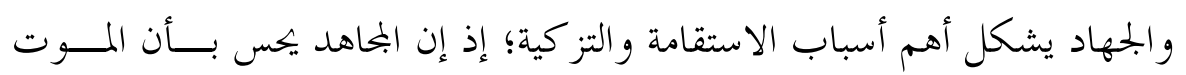

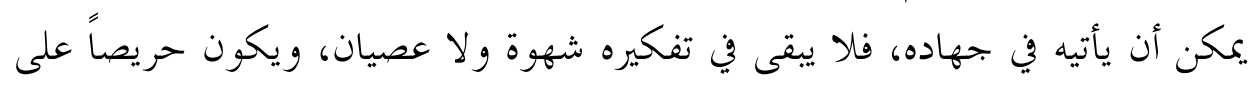


الطاعة والاستقامة والخلق، فبيئة الجهاد تربي على أسمى صفات التزكيــة وأعماهـــــا.

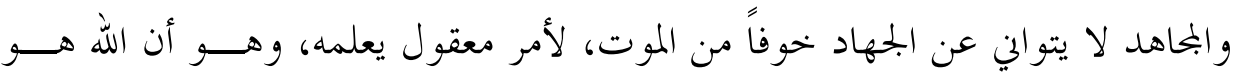

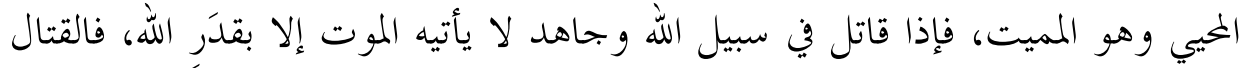
و العدو لا يقرب أجلاً، والنوم في البيت والجمبن والاختباء لا يؤخر أجلاً.

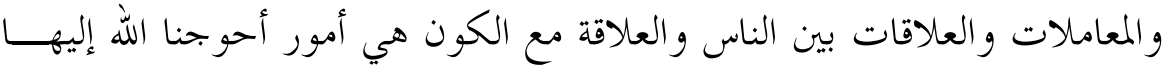

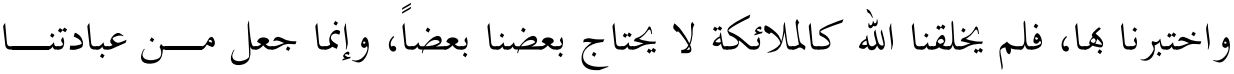
تلك العلاقات و كيف نقيمها وماذا هدف هيا.

و الهدف الأسمى لهذه العلاقات والمعاملات في دين الله أن تنشأ حضارة ذات قــيم

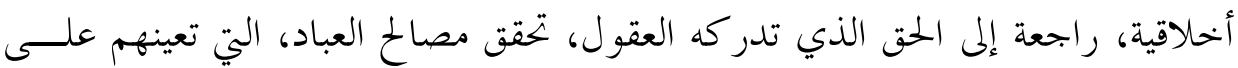

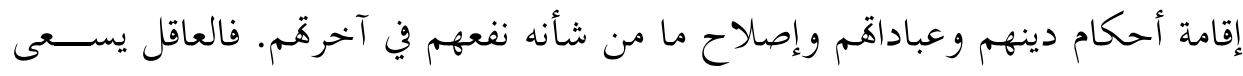
لعمارة الدنيا على الوجه الذي يجقق له حاجاته، ويختصر عليه التعب، و يعينه على إقامة

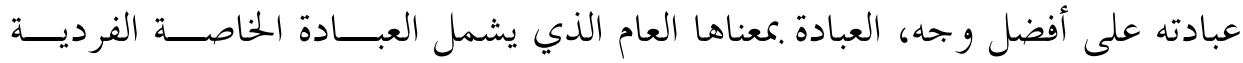

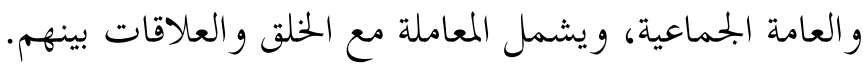

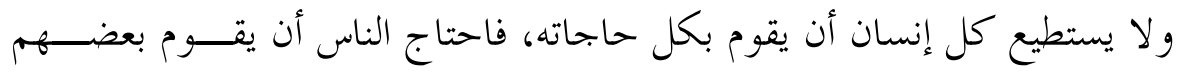

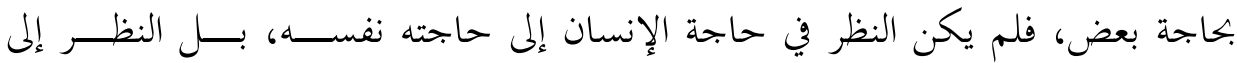

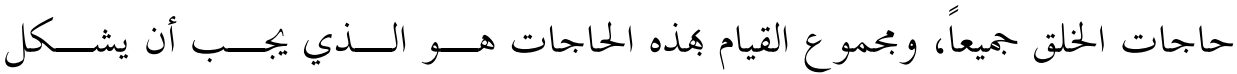

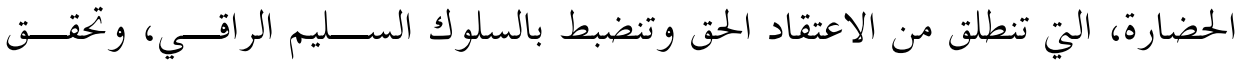

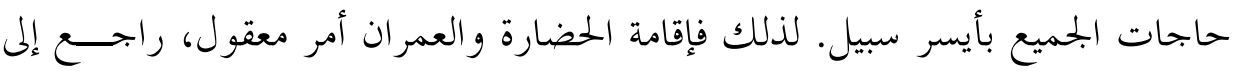

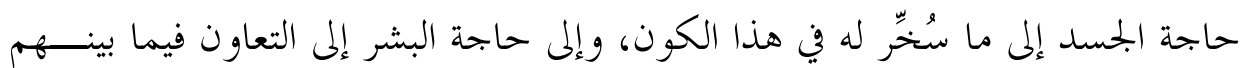

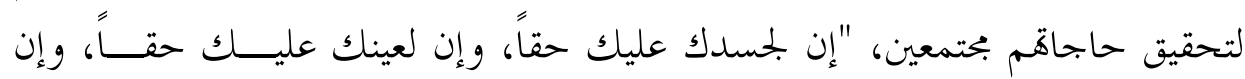

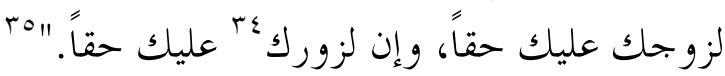


و العمران و التقدم في أسباب المدنية منه ما هو حد و اجب، وهو ما يتحقــق بــــ قضاء حاجات الإنسان وبقاؤه ونصرته للحق الذي يعينه على تحقيق المصالح الأخروية،

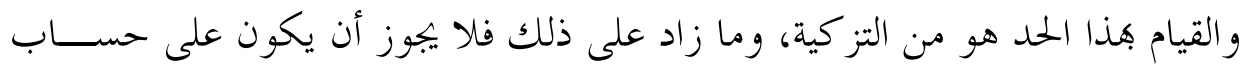

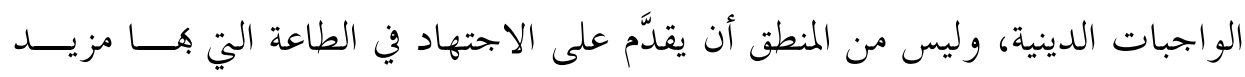
النعيم في الآخرة؛ إذ لا يستوي عقلاً نعيم الدنيا القليل الزائل بنعيم الآخرة المقيم. فليس من المنطقي أن أبين الدنيا وأسرف في الترفه فيها، لأخسر الربح الأخــــروي

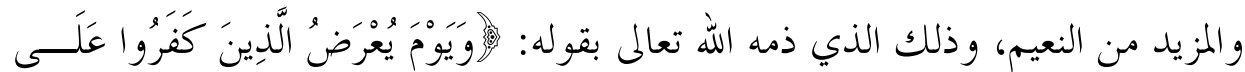

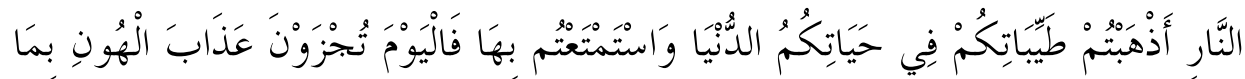

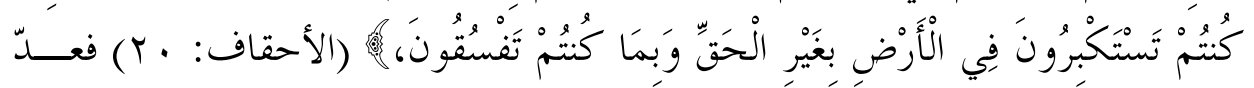

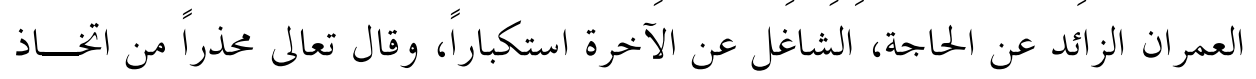

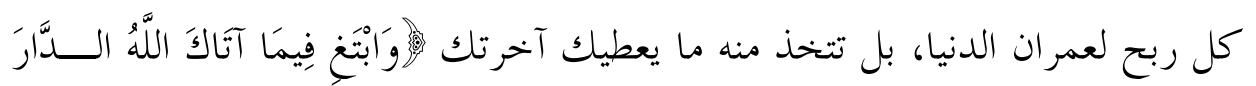

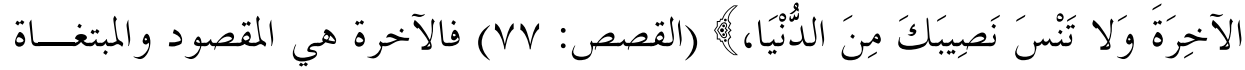

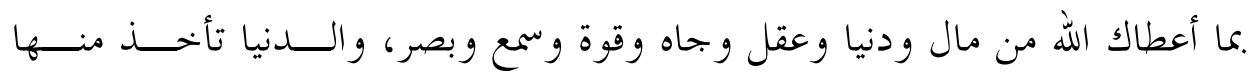

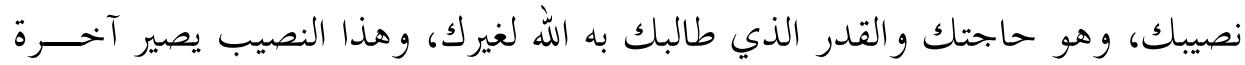
بالنية الصحيحة و بالرجوع إلى حكم الله في ما أعطاك. وليس من المنطقي ولا الشرعي أن أقصر في: العمران، والتقدم، وبناء الحضــارة،

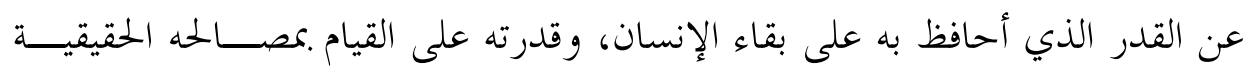

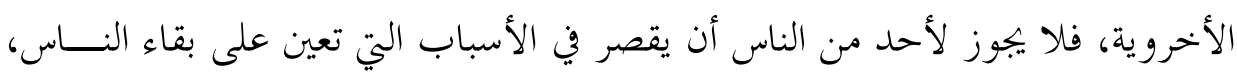
وقضاء حو ائجهم الجسدية الشخصية، ومن حوائجهم ما يعينهم على طاعتهم لله.

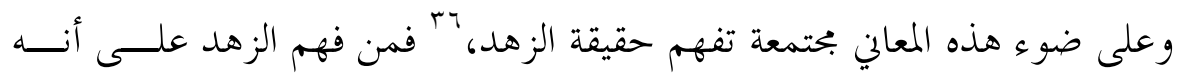

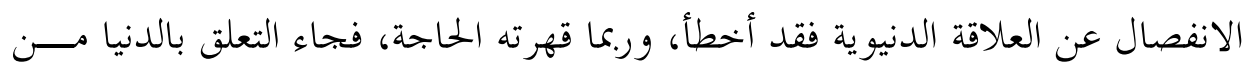

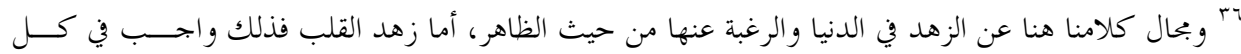
حال، وهو أن لا يجعل الإنسان الدنيا مر اده ومقصوده في النيا في حياته وأعماله. 
جهة حاجته ليخرجه عن زهده الذي يدعيه، ومن تعلق قلبه بالدنيا وشهواتها بـــدعوى

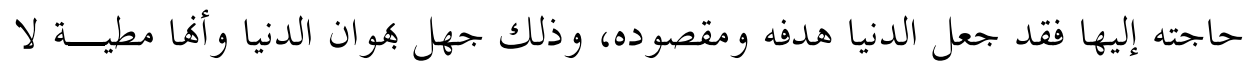

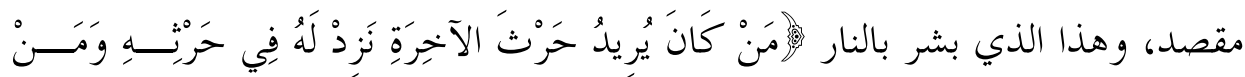

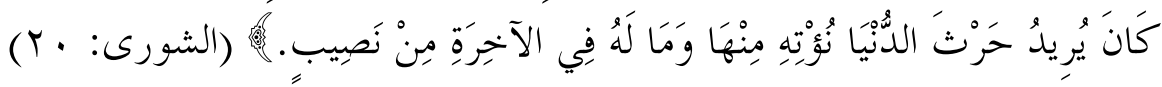
إن الزهد من أعظم أسباب التز كية؛ لأن الإنسان لا يُقبل على ربه، ولا يلتفت إلى

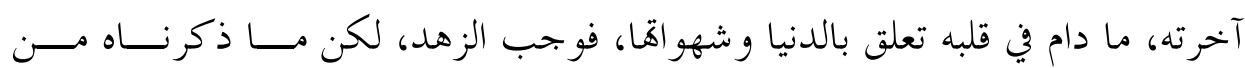

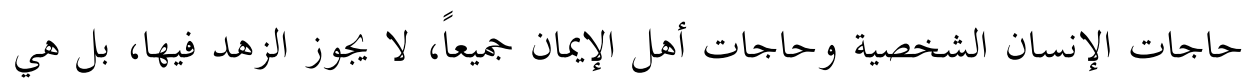
مما أمر الله به، فالالتغات إليها جزء من الإقبال على الله، وجزء من الاستعداد للآخرة.

\section{9. النظر العقلي في الأذواق والكرامات:}

إن لتز كية النفس ثمرات تنتج عنها، منها تلك المقامات التي ذكرنا أفا تقوم علــى

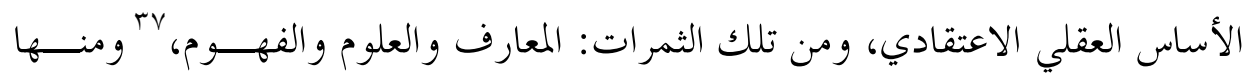

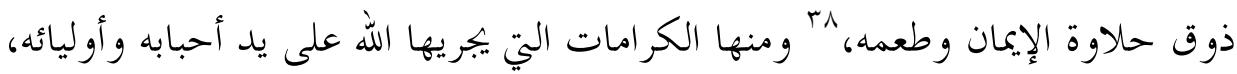

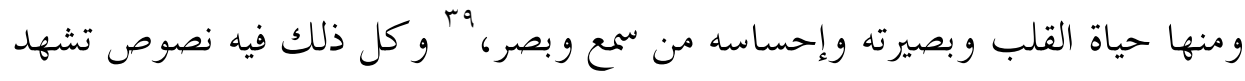

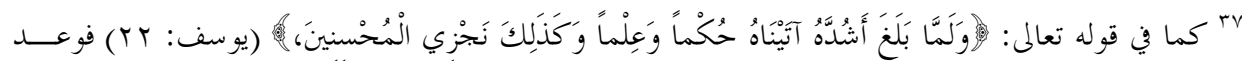

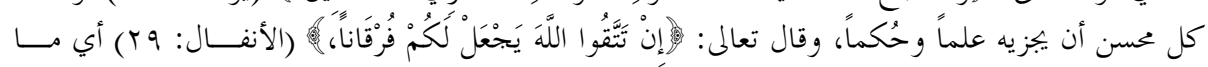

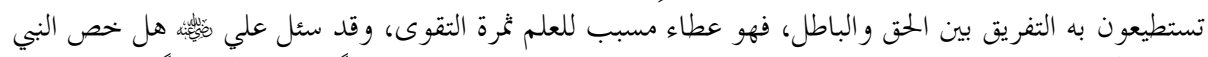

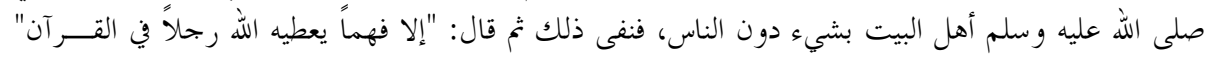

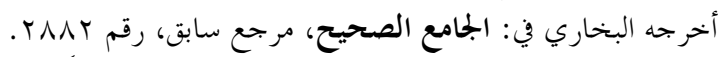

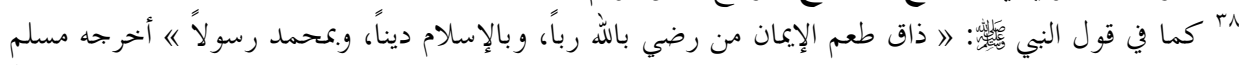

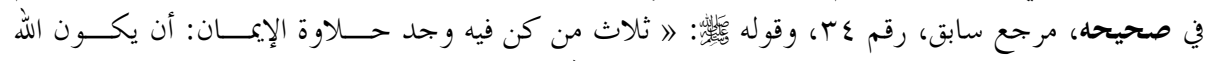

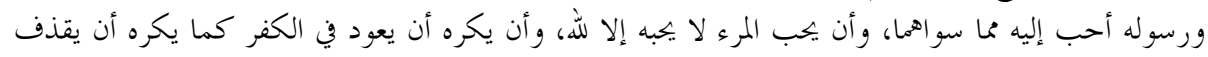

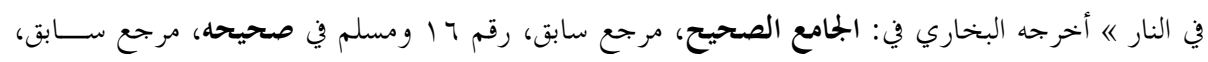
رقم r؟ع.

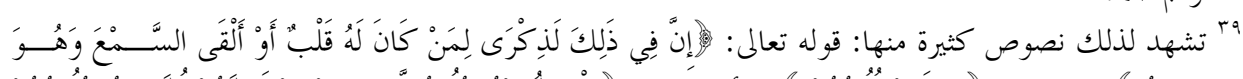

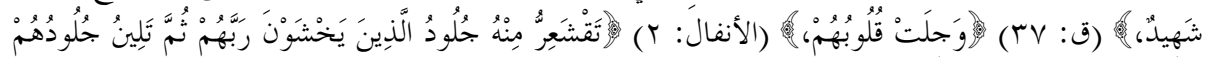

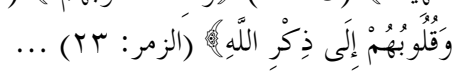




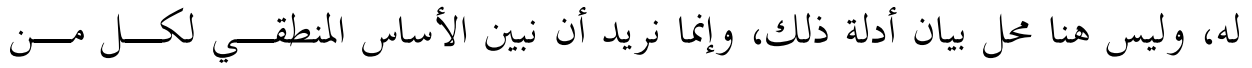
المقامات و المعارف و والكرامات.

أما المقامات كالإخلاص و التو كل والخشنية والرجاء والحب، فقد بيّــــا أساســها

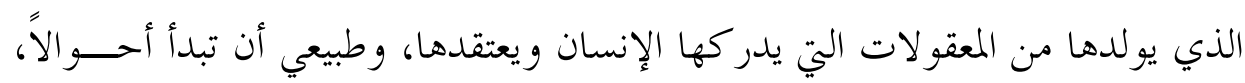

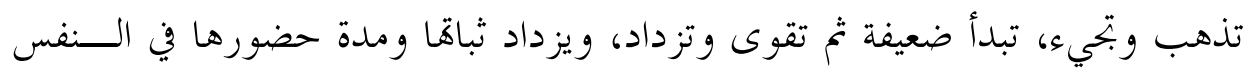

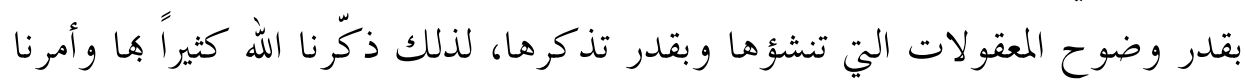

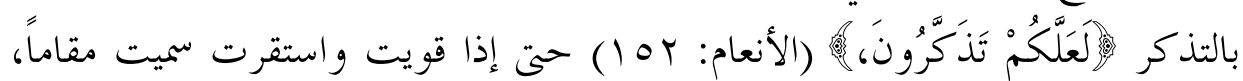
لإقامة الإنسان فيها أو إقامتها واستقر ارها عندها

أما المعارف والعلوم والأذواق الناشئة عن التز كية والإحسان و التقوى، فهـي لا لإلهان

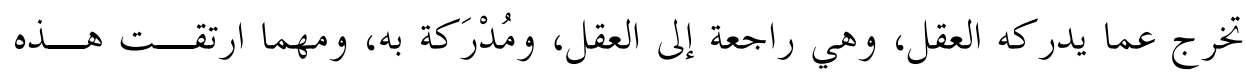

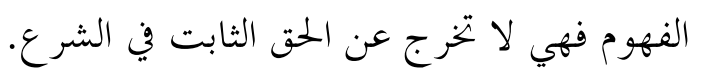

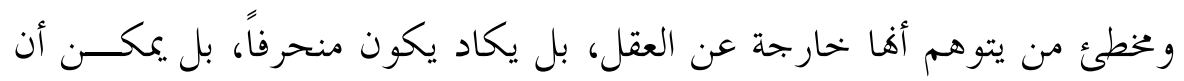

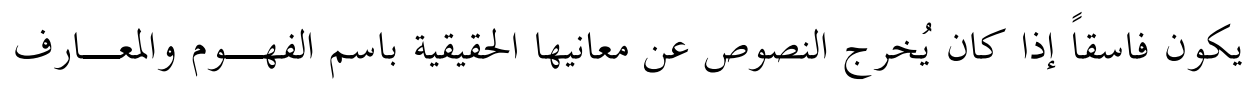

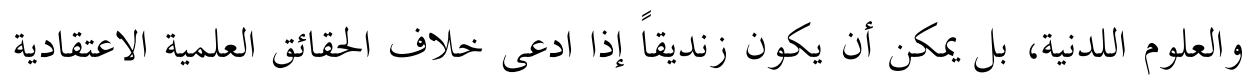

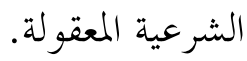

وكل ما في الأمر أن بعض من أعطي فهم بعض المعاني الدقيقة الراقيـة، قـــــلا لا

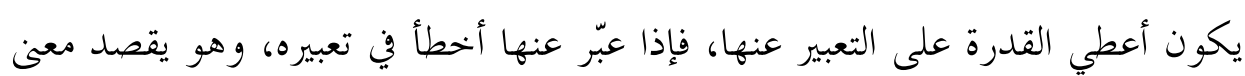

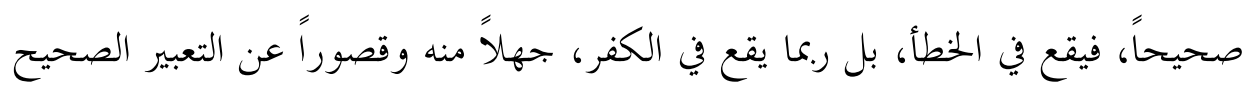

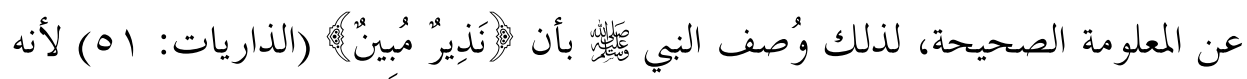
أعطي القدرة على إبانة جميع ما يريد التعبير عنه من الحق.

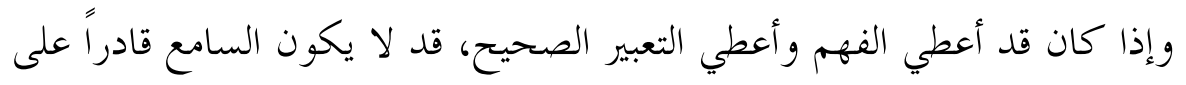

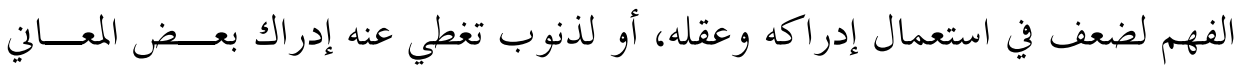




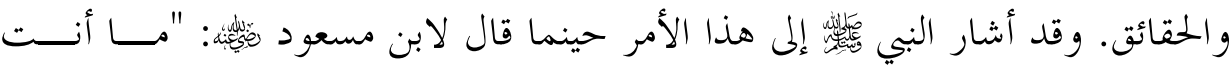

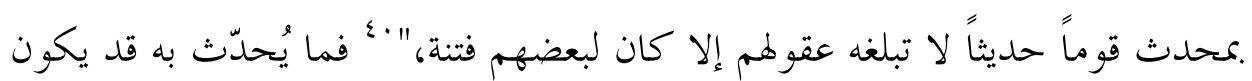

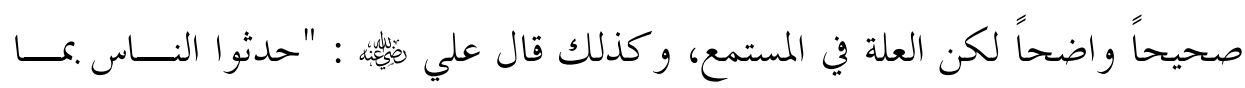

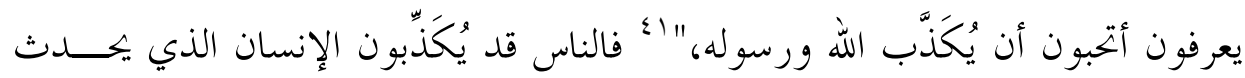

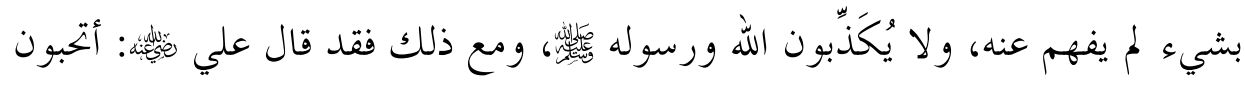

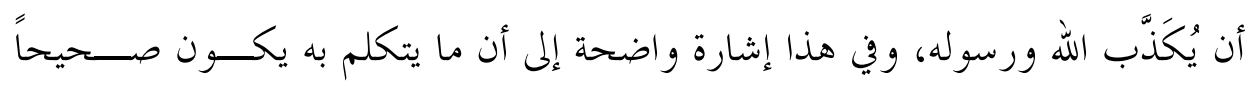

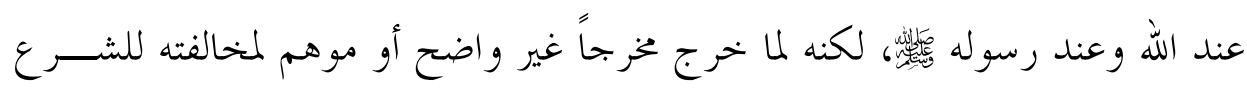

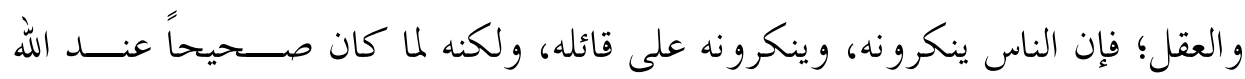
ورسوله فكأنما كذبو هما، لأنه حق عندهان ونها.

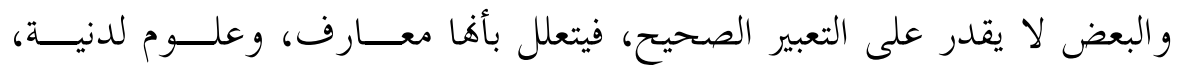

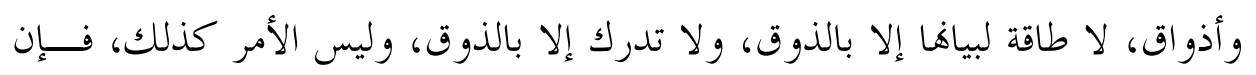

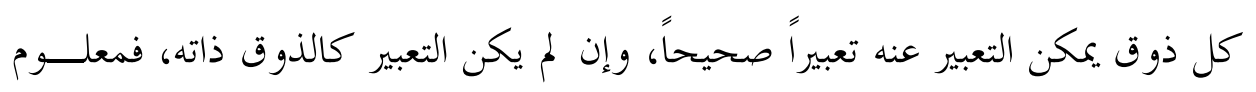

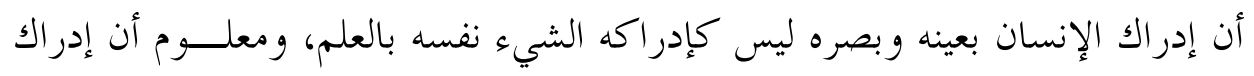

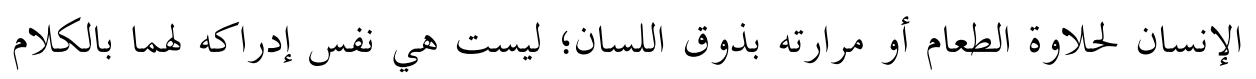

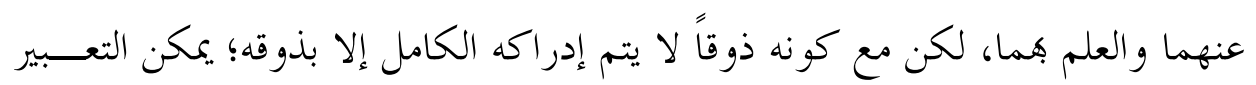

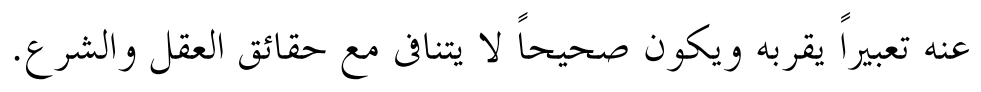

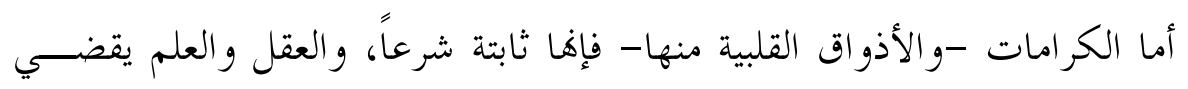

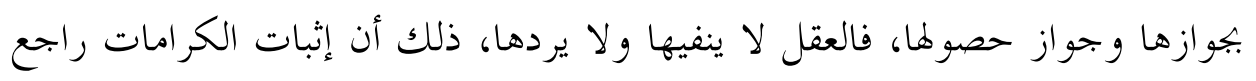

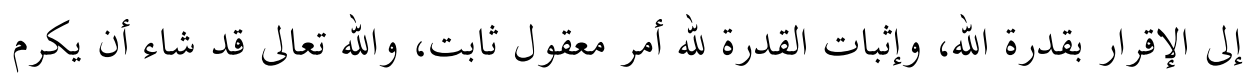

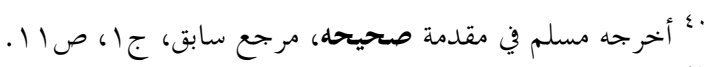

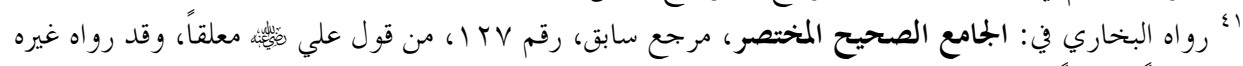

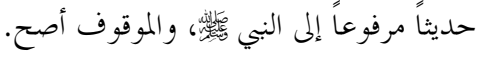




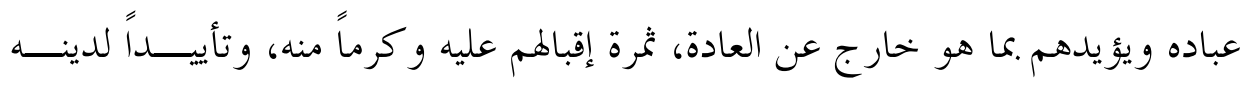

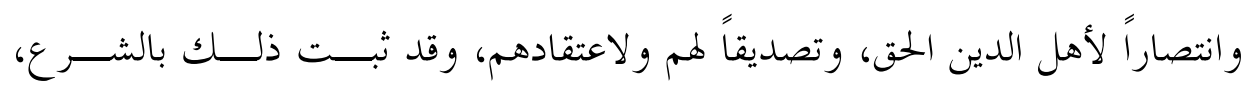

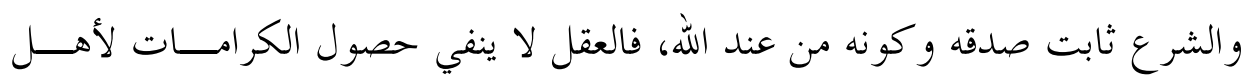
التز كية والتقوى والو لاية، سيما وهي راجعة إلى فضل الله وعطائه وقدرته ومشيئته. والكلام على ثبوت الكرامة في ذاها، يختلف عن مسألة تصــــيقها أو إنكارهـــا،

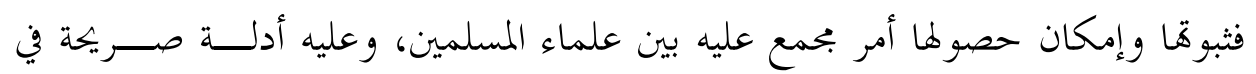

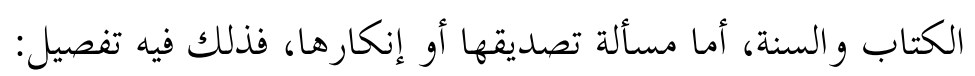
فإذا رأى الإنسان خارقة للعادة فإنه قد يشك فيها بســبب احتمـــال التباســها

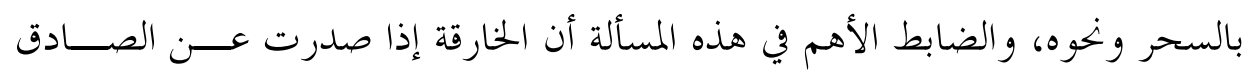

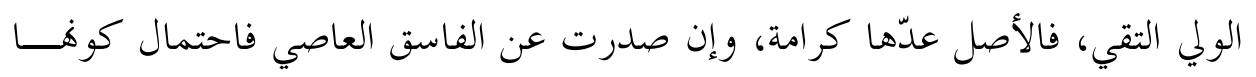

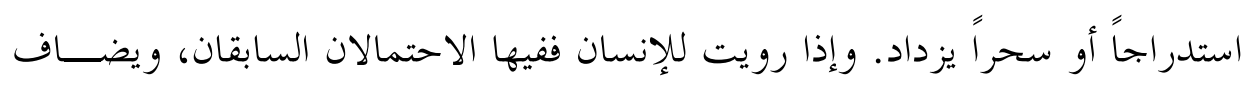

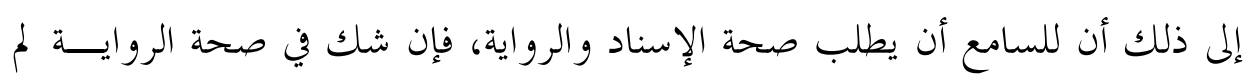

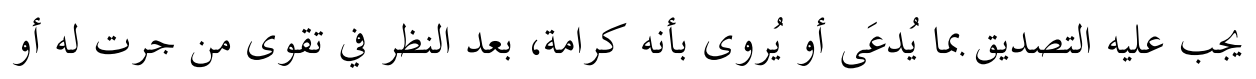
على يديه.

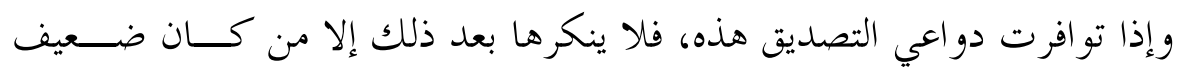

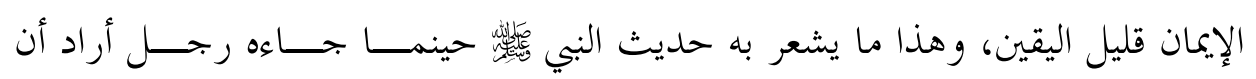

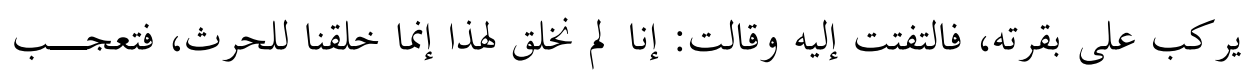

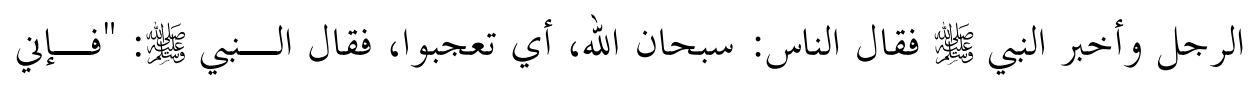

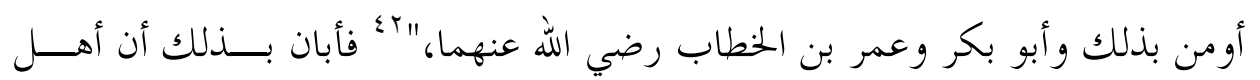
الإيمان و اليقين يصدقون بمثل ذلك، ولا يستغربونه لأنه راجع إلى قدرة الله. 
وكما لا يجوز الإنكار مع توافر دواعي تصديقها، كذلك لا ينبغسي التــهاون في

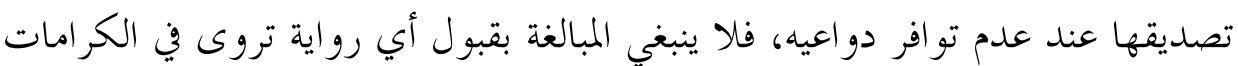
من غير تثبت وتأكد من وقوعها.

\section{خاتمة:}

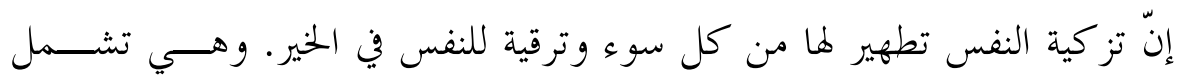

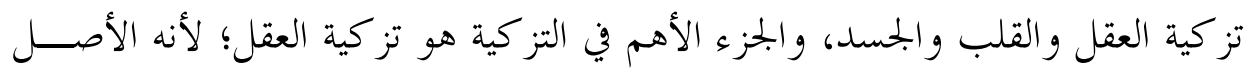

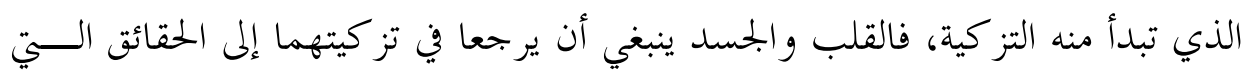

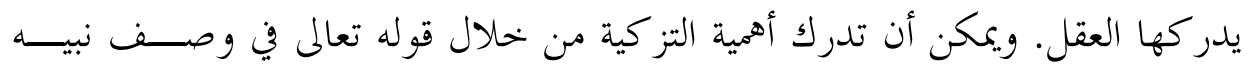

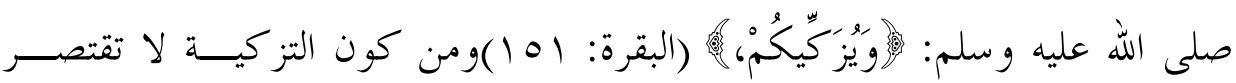
آثارها على الفرد بل تمتد إلى المجتمع. ومن مسائل التز كية أنه لا بد من منع الأهواء النفسية والميول القلبية من الطغيــان

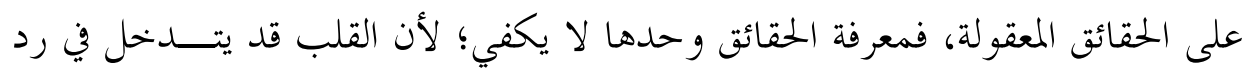

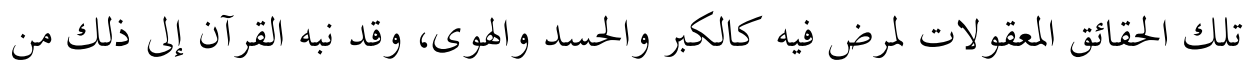
خلال قصص عمن كفروا و كذبوا بالحق.

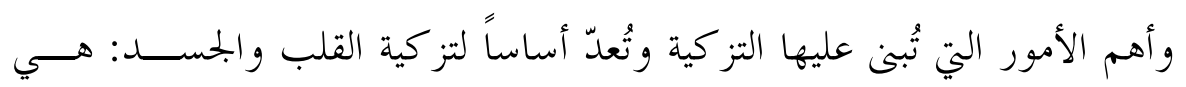

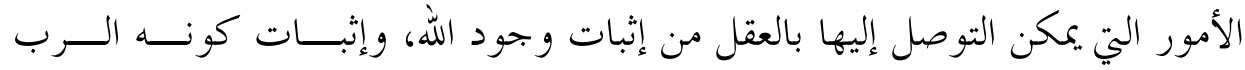

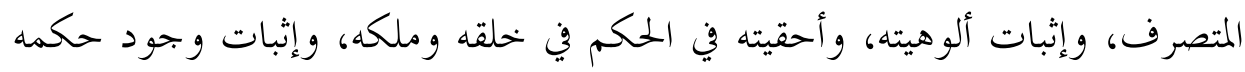

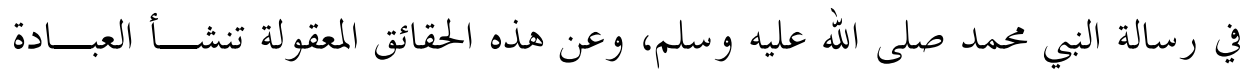

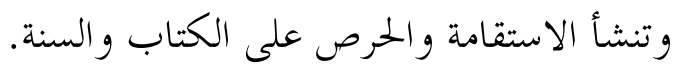

وقناعة الإنسان وإيمانه بأن الله تعالى هو الخالق المالك، يقتضي مــن الإنســان أن

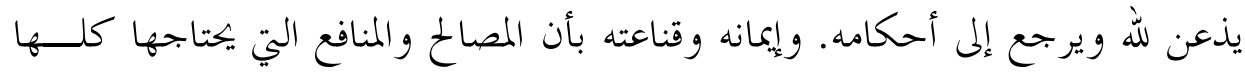


ترجع إلى الله، فليس أحد يعطيه وينفعه أكثر من الله، وقناعته هذه تُنشئ المحبة، والولاء

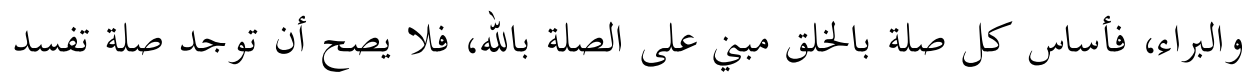

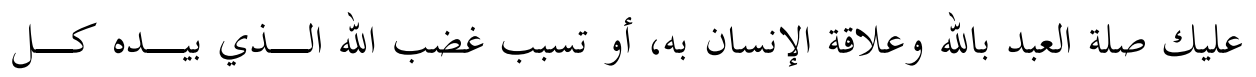
حو ائجنا وخيرنا.

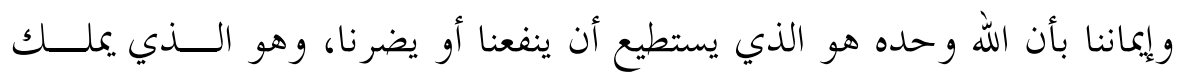

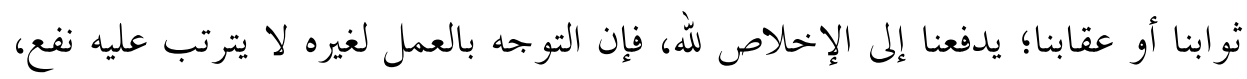

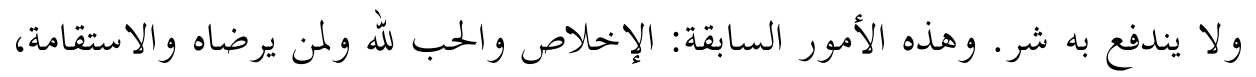
هي من أهم أمور التز كية وعنها تنشأ أهم مسائل التز كية.

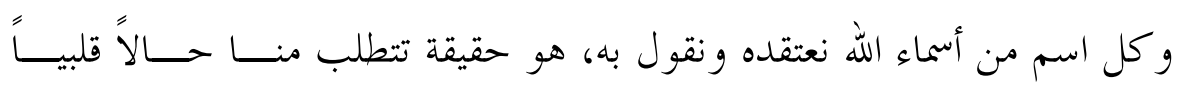

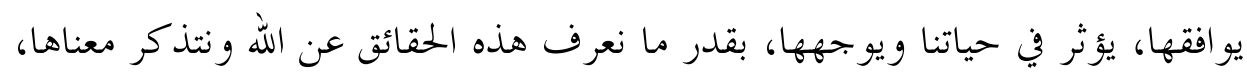

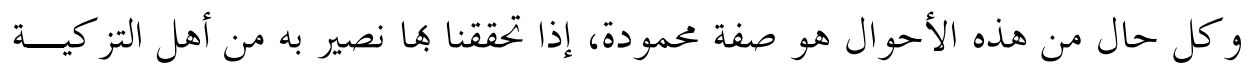

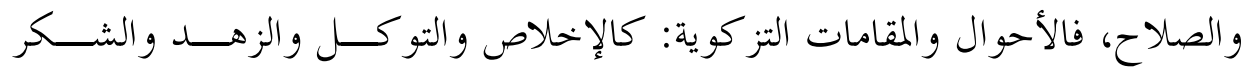

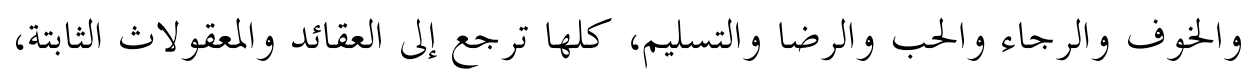

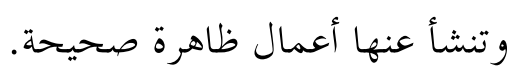

والأخلاق التي شرعت لضبط المعاملات بين الخلائق، شرعت كلها على أســاس

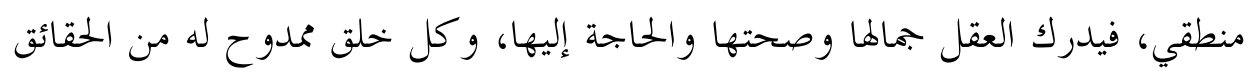
الفكرية ما يقتضيه، وكل خلق مذموم له من الحقائق الفكرية ما يقتضي تر كه.

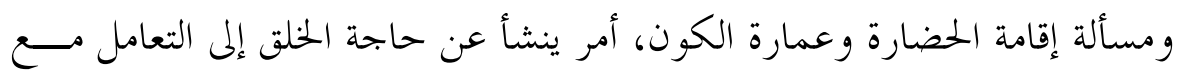

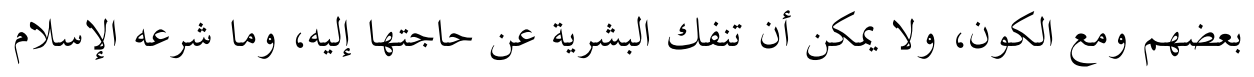

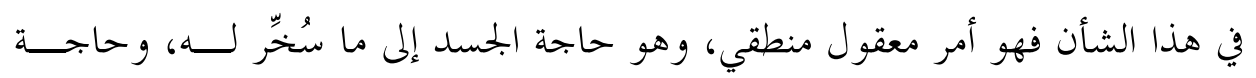

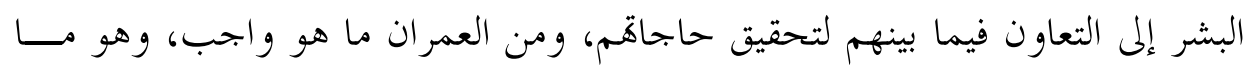


يتحقق به قضاء حاجات الإنسان، وبقاؤه، ونصرته للحق الذي يعينه علــى تحقيــق المصالح الأخروية، و القيام هذا العمران الواجب هو من التزكية ولا يضادها، ومــــــا زاد عن هذا الحد فلا يجبوز أن يكون على حساب الواجبات الدينية، وليس من المنطــق أن يقلَّم على الاجتهاد في الطاعة التي هـا مزيد النعيم في الآخرة؛ إذ لا يستوي عقلاً نعيم الدنيا القليل الزائل بنعيم الآخرة المقيم.

ولا يمكن أن تكون الحقائق والمعارف التي تنشأ عن التزكية خحارجة عــن حسـد العقل، بل كلها راجعة إلى العقل، ومدركة به، ولا يصح الإيهام بأفا فوق طور العقل

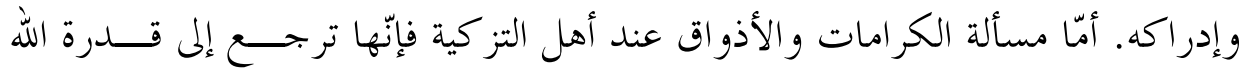
وعطائه، ولا ينبغي المبالغة فيها بقبولها من غير تثبت و تأكد من وقوعها. 